MIGUEL MIES

The symbiotic relationship between Symbiodinium and coral reef larvae: gene expression, fatty acid biochemistry and responses to thermal stress

Thesis presented to the Instituto
Oceanográfico da Universidade de São
Paulo, as part of the requirements for
obtaining the degree of $\mathrm{PhD}$ in
Oceanography.

Supervisor:

Prof. Dr. Paulo Yukio Gomes Sumida

Co-supervisor:

Prof. Dr. Marie-Anne Van Sluys

São Paulo

January 2017 
Universidade de São Paulo

Instituto Oceanográfico

The symbiotic relationship between Symbiodinium and coral reef larvae: gene expression, fatty acid biochemistry and responses to thermal stress

\author{
MIGUEL MIES
}

Thesis presented to the Instituto Oceanográfico da Universidade de São Paulo, as part of the requirements for obtaining the degree of $\mathrm{PhD}$ in Oceanography.

Evaluated on

Prof. Dr.

Grade

Prof. Dr.

Grade

Prof. Dr.

Grade

Prof. Dr.

Grade

Prof. Dr.

Grade 


\section{INDEX}

Acknowledgements................................................................................ i

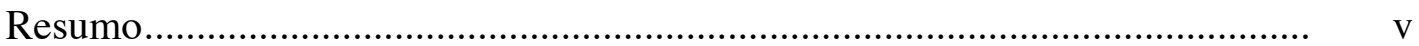

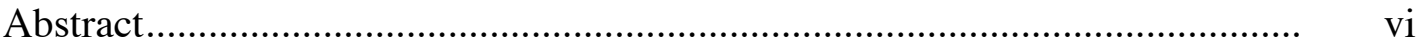

List of tables and figures.......................................................................... vii

Chapter 1 - Introduction. A review on metazoan larvae associated

with Symbiodinium: is there a mutualistic relationship?

Chapter 2 - Expression of a symbiosis-specific gene in Symbiodinium

clade A1 associated with coral, nudibranch and giant clam larvae.

Chapter 3 - Production of three symbiosis-related fatty acids by

Symbiodinium clades A-F associated with coral reef larvae.

Chapter 4 - Bleaching in coral reef larvae associated with

Symbiodinium clades A-F

Conclusions

References 


\section{Special dedication to:}

Prof. Dr. Sergio Mies: father, friend, scientist, professor, role model and hero.

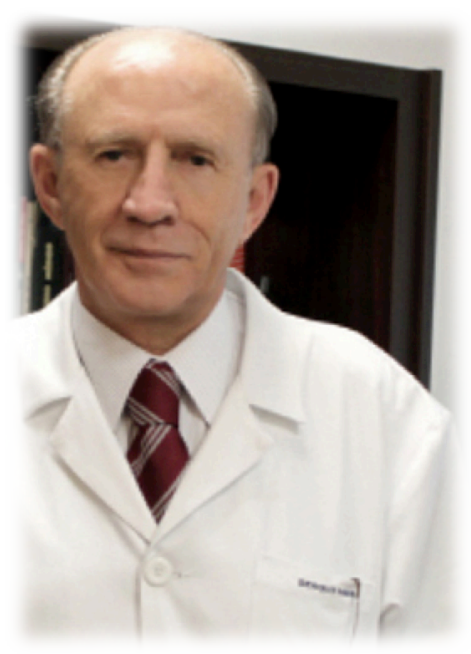

Your passionate dedication is what makes you simply the best at what you do; added to your incorruptible character and respect for the truth, you are the greatest source of inspiration I could ever have.

You have taught me not only how to stand up for the truth, but also how to be curious, which is the first requirement in order to become a scientist. Moreover, you taught me that science is science and not politics. While some still do not recognize that, I do and I will always put science, truth and respect ahead of personal gain, even if that adds significant hurdles to my life. Just like you did. I would never do it differently. I would be honored if I could trail a path like you did: morally, ethically and technically impeccable. Beyond science; it is about being fair.

While I do know that this dedication is meaningless when compared to the gratefulness of countless people whose lives you truly and altruistically saved, I would like to wholeheartedly say that there is no one in the world that deserves this kind of acknowledgement more than you. No one.

Your character and your love for both knowledge and marine life had a crucial and enormous impact on my life. Whatever I am, it is because of you.

My champ. 


\section{ACKNOWLEDGEMENTS}

I will definitely spare no words here. I was raised being taught that gratitude is something very important and I greatly embrace it. More so today than ever, science is not something that one does alone; therefore I will thoroughly thank all the people that were involved and helped during these arduous five years; not only the scientists, colleagues and technicians, but also the family and friends that were supportive and helpful during this time.

Firstly I would like to thank my parents, Fatima and Sergio, who did their absolute best in shaping me as a person, teaching me good values, respect and ethics. Everything that I may achieve in this life, both professionally and emotionally, can be traced back to what they did and sacrificed for me. I would like to thank my two beautiful and loving sisters, Mariana and Juliana (meu garoto! - nobody makes me feel better than you do!) as they also played a key role in my upbringing. Big role. I also thank all my family members, especially Leila, Latife and Marlene. Of course I could not forget to mention some of the amazing friends that helped me in the process; these include my great friend Du, Camila, Fanny and the glorious Chapolim. Also, the amazing long-time friends from IO-USP's Turma IV. And I need to mention Prof. Jorge Amaro, who wisely teaches me how to improve. Truly, "a north star roam".

Many people played different parts in the work that I have done in these years. The most important one is, without a shadow of doubt, my supervisor, mentor, friend and a person for whom I have great admiration and respect, Paulo Sumida. Thank you for allowing me to pursue my own line of research, for the support and for all of the different manners in which you helped me. I hope to perform research at your side for decades to come. I could not ask for a better supervisor. I would also like to thank my co-supervisor, Marie-Anne Van Sluys, for providing me with tremendous infrastructure and a great environment to learn and produce top quality science. 
There are two colleagues that deserve special praise: Arthur Güth and Linda Waters. Apart from helping me set up the larval runs in Bahia, their input had crucial impact on the shaping of this thesis. They presented me with a lifeline when things went difficult. You guys are great. Arthur, you have no idea how much I admire you and there is nothing better than discussing science with you.

I need to thank all the members of our lab, especially Maurício (you are absolutely great!) and also Joan, Maria, Romina, Olívia, Felipe, Karin, Betina, Paula, Camila, Bruno and all the undergraduate students. I must also extend my gratitude to the talented team at the GaTE lab: Andréia, Érika, Bruno, Gui, Dani, Cushla, Paula, Gesiele, Geovani, Vânia, Renata, Fabi, Zé, Raquel, Ana, Tatiana and the amazing Jonas, Andrés and Luiz Fernando Zuleta. I also thank the fantastic team at the Instituto de Química: Prof. Sayuri Miyamoto, the ever-helpful Adriano and Priscilla. My gratitude is also extended to Mayza Pompeu, Flávia Saldanha-Corrêa (for patiently culturing so much zooxanthellae for me) and the absolutely fantastic Diego Castillo for providing me with assistance at crucial moments.

My sincere thanks also goes to many of the professors at the IO-USP who have kindly supported us, especially Frederico Brandini, Marcos Santos and Luz Amélia VegaPérez. I also need to acknowledge researchers from abroad that have helped us: Mary Alice Coffroth, Christian Voolstra, Todd LaJeunesse, Virginia Weis, Arthur Grossman, Tingting Xiang, Bishoy Hanna and Mónica Medina.

I acknowledge FUNDESPA for all of their tremendous help during challenging times (especially Bauer Rachid, Ilson Silveira, Luiz Tommasi, Salvador Gaeta and Lucas Camargo); also the World Aquaculture Society (mainly Sandra Shumway and Wagner Valenti) for their help and recognition. I thank and commend the amazing Coral Vivo Institute (especially Clóvis Castro, Débora Pires and the always-efficient Emiliano Calderón) for helping us with the infrastructure for the coral larvae experiments.

I can only thank those students that I had the pleasure of supervising or co-supervising: Gabriela Mitsuhashi, Arthur Tenório, Thomás Banha, Estela Monteiro and Marina Botana. I have learned a lot from you. I also thank Lucas Canela, Lucas Gonçalves and 
Kevin Miyazaki for their patience and for holding the fort when I was away from EcoReef; you guys are the best.

Finally I thank my very own family: Thaís, my beautiful fiancée, love of my life and the best thing that has happened to me; and also Sofia, the best child anyone could ask for. I love you both. Our lives together will be fantastic.

I hope to have remembered everyone.

---Miguel Mies---

"whether 'tis nobler in the mind to suffer the slings and arrows of outrageous fortune, or to take arms against a sea of troubles, and by opposing end them?"

- W. Shakespeare 

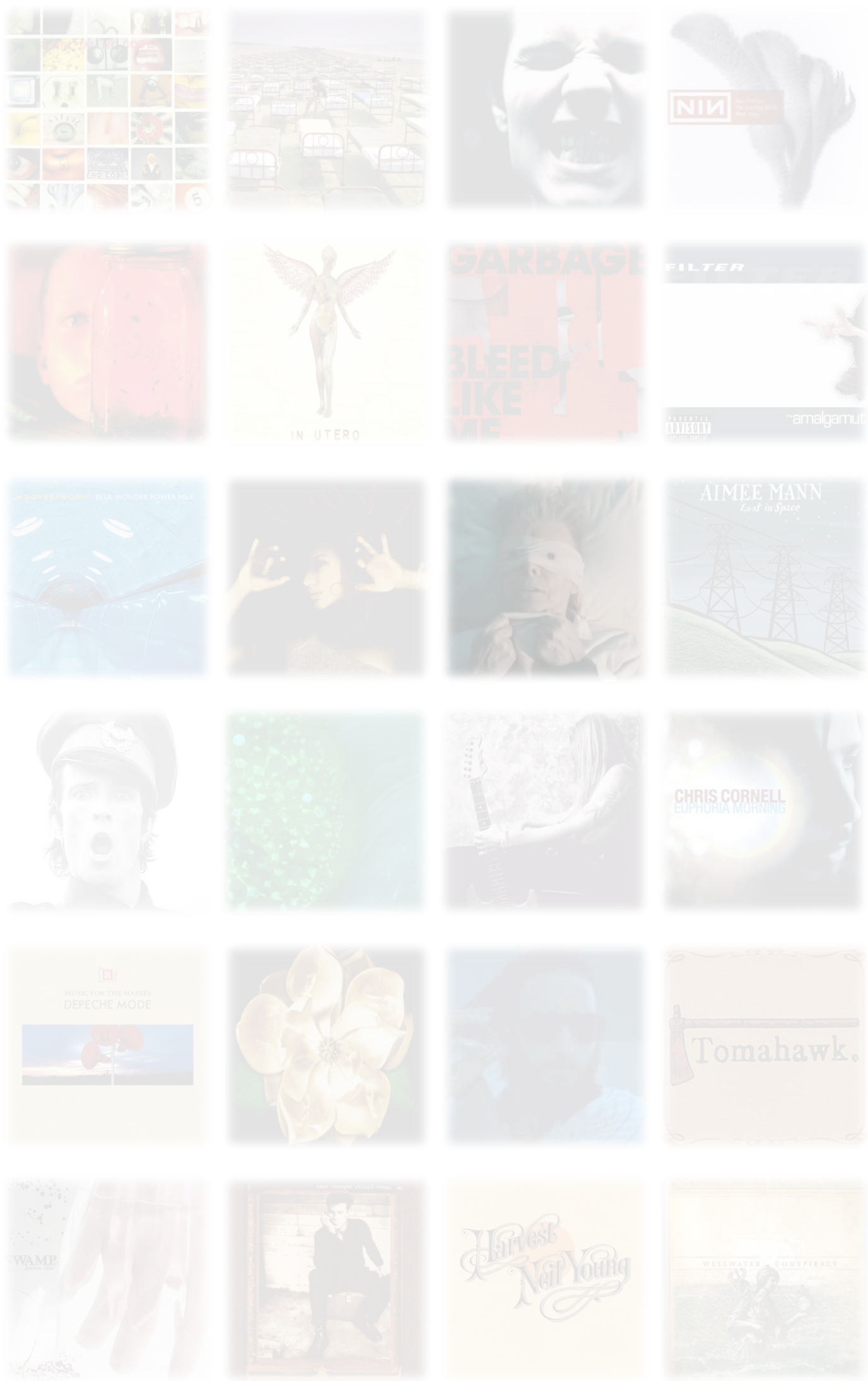
Muito pouco é conhecido sobre a associação entre dinoflagelados do gênero Symbiodinium e larvas de metazoários. Essa tese realizou três experimentos sobre a associação entre Symbiodinium e larvas de Mussismilia hispida (coral), Berghia stephanieae (nudibrânquio) e Tridacna crocea (vieira gigante). $\mathrm{O}$ primeiro experimento verificou a expressão de um gene específico para a relação simbiótica em Symbiodinium A associado com as larvas dos três hospedeiros. O segundo experimento quantificou a produção de ácidos graxos nos clados A-F de Symbiodinium também associados com as larvas dos três hospedeiros; o terceiro monitorou a perda de simbiontes nos três tipos larvais associados com os clados A-F, em temperaturas de 26,29 e $32^{\circ} \mathrm{C}$. Os principais resultados mostram que: i) um gene específico para a simbiose é expresso por Symbiodinium A associado com M. hispida e T. crocea, mas não com B. stephanieae; ii) o ácido graxo DHA é produzido em quantidades significantemente maiores pelos clados A e C associados com M. hispida e $T$. crocea; e iii) M. hispida e $T$. crocea associadas com Symbiodinium A e C possuem taxas de perda de simbiontes significantemente menores do que os demais. Esses resultados mostram que os clados $\mathrm{A}$ e $\mathrm{C}$ estabelecem um mutualismo mais robusto com $M$. hispida e $T$. crocea, mas não há relação mutualística entre Symbiodinium e B. stephanieae.

Descritores: simbiose, ecologia larval, Scleractinia, Bivalvia, Gastropoda, zooxantelas 


\begin{abstract}
Very little is known about the association between Symbiodinium dinoflagellates, which perform the majority of primary production in coral reefs, and metazoan larvae. This thesis performed three experiments on the association between Symbiodinium and Mussismilia hispida (coral), Berghia stephanieae (nudibranch) and Tridacna crocea (giant clam) larvae. The first experiment monitored the expression of a symbiosisspecific gene in Symbiodinium clade A associated with the three larval forms during a 72-h window. The second experiment quantified the production of symbiosis-related $\omega 3$ fatty acids in Symbiodinium clades A-F also associated with the three larval hosts and the third experiment verified bleaching rates at 26,29 and $32^{\circ} \mathrm{C}$ in the larvae associated with clades A-F. The main results show that i) a symbiosis-specific gene is expressed by Symbiodinium A associated with M. hispida and T. crocea larvae, but not with $B$. stephanieae; ii) the DHA fatty acid is produced in significantly higher amounts by clades A and C associated with M. hispida and T. crocea larvae; and iii) that M. hispida and T. crocea larvae associated with Symbiodinium A and C have significantly lower bleaching rates. These findings suggest that clades $\mathrm{A}$ and $\mathrm{C}$ establish a more robust mutualism with $M$. hispida and T. crocea larvae, but there seems to be no mutualism between Symbiodinium and B. stephanieae.
\end{abstract}

Keywords: symbiosis, larval ecology, Scleractinia, Bivalvia, Gastropoda, zooxanthellae 


\section{LIST OF TABLES AND FIGURES}

\section{Chapter 1}

Table 1: Larval forms associated with Symbiodinium..................................... 04

Figure 1: Phylogenetic relationship of Symbiodinium clades........................... 07

Figure 2: Steps for the establishment of mutualism........................................ 11

\section{Chapter 2}

Table 1: Ecological aspects of Symbiodinium hosts....................................... 17

Figure 1: Host broodstock and larvae used in the experiment.......................... 20

Figure 2: Phylogeny for $\mathrm{H}^{+}$-ATPase and RuBisCO........................................ 22

Table 2: $\mathrm{H}^{+}$-ATPase expression................................................................. 23

\section{Chapter 3}

Table 1: Acquisition and mitotic index of Symbiodinium clades..................... 33

Figure 1: Survival and growth of larvae associated with Symbiodinium........... 34

Figure 2: SDA and DPA content ............................................................. 35

Figure 3: DHA content ......................................................................... 37

\section{Chapter 4}

Figure 1: Bleaching experimental design...................................................... 45

Table 1: Acquisition of Symbiodinium ........................................................... 47

Figure 2: Survival of larvae exposed to thermal stress..................................... 48

Figure 3: Growth of larvae exposed to thermal stress...................................... 49

Figure 4: Chlorophyll- $a$ content of larvae exposed to thermal stress.................. 50 


\title{
CHAPTER ONE: INTRODUCTION
}

\section{A review on metazoan larvae associated with Symbiodinium: is there a mutualistic relationship?}

\author{
Mies, M. $^{{ }^{*}} \&$ Sumida, P. Y. G. ${ }^{1}$ \\ ${ }^{1}$ Oceanographic Institute, University of São Paulo. Praça do Oceanográfico, 191 - 05508-120
}

São Paulo, SP - Brazil.

* Corresponding author: miguel.mies@usp.br

\begin{abstract}
The metazoan-Symbiodinium association has been extensively documented for adult hosts. However, very little is known about this association during host larval development. Four different metazoan phyla produce larvae associated with Symbiodinium, Porifera, Cnidaria, Acoelomorpha and Mollusca, all of which present significant diversity in larval forms, manner of symbiont acquisition and also different requirements on the symbiont presence for successful metamorphosis. Larvae have recognition mechanisms for selecting symbionts of different identities, which may have an impact on larval growth and fitness. Very little is known about metabolical exchange between coral reef larvae and Symbiodinium, but it seems to be active in some cases, despite being minimal. Molecular studies show that host larvae transcriptome is nearly unaltered after symbiont acquisition. However, a symbiosis-specific gene has been identified in Symbiodinium and similar genes are currently being described for host organisms. Climate change has a significant impact on the association, as coral reef larvae have a bleaching threshold of $28-30^{\circ} \mathrm{C}$, but symbiont identity may attenuate the negative effects. It is questionable whether a mutualistic symbiosis is usually active between Symbiodinium and coral reef larvae, as most studies have not been unable to confirm this. However, some reports of metabolite exchange and differential gene expression show that symbiosis is active in some cases.
\end{abstract}

Keywords: symbiosis, zooxanthellae, coral reef, larval ecology, planula, veliger 


\section{Introduction}

Marine invertebrates typically present indirect development and their planktonic larvae act as the dispersive stage. This a particularly important adaptation, as it directly influences distribution and abundance, and also enables geographical range expansion and recovery of populations (Strathmann et al., 2002). Many factors influence larval development and its dispersal, such as oceanographic conditions, predation avoidance by planktivorous organisms and energy reserves and feeding abilities (Pechenik, 1990). As a response to such wide array of scenarios, there is a significant diversity of larval forms presented by metazoan organisms (Wray and Raff, 1991). Certain larval kinds are planktotrophic and required to feed, thus presenting specialized organs, while others are lecithotrophic and can survive through metamorphosis while relying solely on endogenous reserves (Thorson, 1950; Pechenik, 1999).

In coral reefs, however, certain larval forms must not only feed in the plankton, but also acquire symbionts (Fitt et al., 1986; Mieog et al., 2009; Ramos and Banaszak, 2014). Many metazoan phyla, especially scleractinian corals in Cnidaria, engage in a mutualistic symbiosis with the photosynthetic dinoflagellates of the genus Symbiodinium (Stat et al., 2006; Venn et al., 2008). The majority of these corals are broadcast spawners and newly-formed planula larvae, while lecithotrophic, must acquire their symbionts horizontally (Harrison and Wallace, 1990; Baird et al., 2009; Harrison, 2011). The planktonic larvae acquire different free-living Symbiodinium strains from the environmental pool before selecting a specific(s) strain(s) at a later stage (Belda-Baillie et al., 1999; Weis et al., 2001; Coffroth and Santos, 2005).

While studies on animal-dinoflagellate symbioses have advanced significantly, there is still an overall lack of knowledge about this relationship during host larval development, especially about metabolite exchange and symbiosis-related differential gene expression. In fact, this lack of information raises the question on whether the mutualistic relationship is already established during host larval development. Likewise, while there is much information about the impacts of climate change and anthropogenic influence on adult and symbiotic coral reef specimens (Hoegh-Guldberg, 1999; Hughes et al., 2003; Hoegh-Guldberg et al., 2007), very little is known about the impacts on Symbiodinium-associated larval forms. Therefore, this review has the purpose of compiling, describing and interpreting the available data on metazoan larva- 
Symbiodinium associations, with emphasis on the ecological, molecular and biochemical relationship, evolution and influence of environmental change.

\section{Metazoan larvae associated with Symbiodinium}

Four different metazoan phyla produce larval forms that associate with Symbiodinium: Porifera, Cnidaria, Acoelomorpha and Mollusca (Table 1). Two protist taxa are also known to associate with Symbiodinium, Foraminifera (Pochon and Gates, 2010) and Ciliophora (Mordret et al., 2016). Metazoan larvae acquire symbionts in two different ways: vertically (transmitted to the offspring in parental oocytes) or horizontally by oral ingestion during larval development. Both strategies have their advantages. Vertical transmission ensures that a successful symbiont strain is supplied to the larvae (Wilkinson and Sherratt, 2001), while horizontal transmission allows for the larvae to acquire a diversity of symbionts, some of which may be more compatible to different environmental conditions encountered after dispersal (Baird et al., 2007).

Sponges and acoelomorph worms are the two groups in which significantly little is known about their association with Symbiodinium, especially during larval development. Within sponges, the association with Symbiodinium seems to be largely restricted to the family Clionaidae (Hill et al., 2011) and parenchymella larvae contain parentally-seeded symbionts (Mariani et al., 2000; 2001). In the case of acoelomorph worms, the genus Waminoa harbors two different symbiotic dinoflagellates, Symbiodinium and Amphidinium, which are also transmitted vertically (Barneah et al., 2007b). Other acoelomorph genera are known to associate with Symbiodinium, but no information regarding their larval development has been reported (Trench and Winsor, 1987).

In the case of cnidarians, while a massive amount of knowledge has been produced on their association with Symbiodinium, there are still relatively few studies on the larva-Symbiodinium association. Approximately $80-90 \%$ of reef-building coral species (Scleractinia) are broadcast spawners and acquire symbionts horizontally (Harrison and Wallace, 1990; Baird et al., 2009; Harrison, 2011). On the other hand, many of the less common brooding species transmit symbionts vertically, most notably in the family Pocilloporidae (Baird et al., 2009). In the case of soft coral species 
Table 1 Host taxa and their larval stages associated with Symbiodinium, also describing mode of symbiont transmission and addressing whether the presence of Symbiodinium in larval tissues is critical for successfully attaining metamorphosis.

\begin{tabular}{lcccc}
\hline Host taxon & $\begin{array}{c}\text { Mode of } \\
\text { Symbiodinium } \\
\text { transmission }\end{array}$ & $\begin{array}{c}\text { Larval stages } \\
\text { associated with } \\
\text { Symbiodinium }\end{array}$ & $\begin{array}{c}\text { Symbiodinium } \\
\text { acquisition as a } \\
\text { requirement for } \\
\text { metamorphosis }\end{array}$ & References \\
\hline Porifera & vertical & parenchymella & $\mathrm{n} / \mathrm{a}$ & Mariani et al. $(2000 ; 2001)$
\end{tabular}

Cnidaria

\begin{tabular}{|c|c|c|c|c|}
\hline Scyphozoa & horizontal & planula & no & $\begin{array}{l}\text { Hofmann et al. (1996); Sachs } \\
\text { and Wilcox (2006); Mellas et al. } \\
\text { (2014) }\end{array}$ \\
\hline Actiniaria & $\begin{array}{c}\text { vertical and } \\
\text { horizontal }\end{array}$ & planula & $\mathrm{no}^{\mathrm{a}}$ & $\begin{array}{l}\text { Bythell et al. (1997); Schwarz et } \\
\text { al. (2002); Hambleton } \text { et al. } \\
\text { (2014) }\end{array}$ \\
\hline Alcyonacea & $\begin{array}{c}\text { vertical and } \\
\text { horizontal }\end{array}$ & planula & no & $\begin{array}{l}\text { Benayahu et al. }(1988 ; 1992) \text {; } \\
\text { Achituv et al. }(1992) ; \text { Slattery et } \\
\text { al. (1999); Barneah } \text { et al. }(2004)\end{array}$ \\
\hline Scleractinia & $\begin{array}{c}\text { vertical and } \\
\text { horizontal }\end{array}$ & planula & no & $\begin{array}{l}\text { Weis et al. (2001); Marlow and } \\
\text { Martindale (2007); Harii et al. } \\
\text { (2009); Mieog et al. (2009); } \\
\text { Erwin and Szmant (2010) }\end{array}$ \\
\hline elomorpha & vertical & Müller's larva & $\mathrm{n} / \mathrm{a}$ & $\begin{array}{l}\text { Barneah et al. }(2007 \mathrm{a} ; \mathrm{b}) \text {; } \\
\text { Hikosaka-Katayama et al. } \\
\text { (2012) }\end{array}$ \\
\hline
\end{tabular}

Mollusca

\begin{tabular}{|c|c|c|c|c|}
\hline Gastropoda & $\begin{array}{l}\text { vertical and } \\
\text { horizontal }\end{array}$ & veliger & yes $^{b}$ & $\begin{array}{l}\text { Kempf (1984); Carroll and } \\
\text { Kempf (1990) Banaszak et al. } \\
\text { (2013); García Ramos and } \\
\text { Banaszak (2014) }\end{array}$ \\
\hline Bivalvia & horizontal & $\begin{array}{l}\text { veliger and } \\
\text { pediveliger }\end{array}$ & yes & $\begin{array}{l}\text { Fitt and Trench (1981); Fitt et } \\
\text { al. }(1984 ; 1986) \text {; Heslinga et al. } \text {. } \\
(1984 ; 1990) \text {; Mies } \text { et al. }(2012)\end{array}$ \\
\hline
\end{tabular}

\footnotetext{
${ }^{a}$ in the case of Aiptasia sp.; unknown for other anemones.

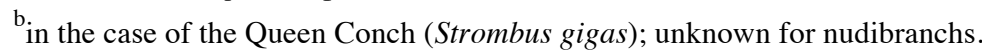

n/a - not applicable.
}

(Alcyonacea), the incidence of vertical transmission seems to be higher (Benayahu et al., 1988; Achituv et al., 1992) than for scleractinians. Coral larvae are typically lecithotrophic (Morse et al., 1996) and while symbiont acquisition may improve host fitness, it does not seem to be a requirement for metamorphosis (Schwarz et al., 1999; 
Mieog et al., 2009). In the case of other cnidarians such as anemones and jellyfish, there is still very little information on the role of Symbiodinium in their larval ecology.

Among mollusks, giant clams (subfamily Tridacninae) are possibly the most conspicuous species associated with Symbiodinium. In this group symbiont acquisition is horizontal (Fitt and Trench, 1981) and a requirement for successful metamorphosis (Mies et al., 2017a). Differently from other metazoan hosts, symbionts are only acquired during the second larval stage (veliger), as the first larval stage is a nonfeeding trochophore (Fitt et al., 1984; Heslinga et al., 1984). To date, giant clams are also the only known Symbiodinium hosts that during larval development do not move symbionts from the digestive tract or equivalent to endodermal tissues (Schwarz et al., 2002; Marlow and Martindale, 2007; Huang et al., 2008), as they remain in the digestive tract throughout the larval development (Fitt et al., 1986; Hirose et al., 2006). The other mollusk group associated with Symbiodinium is Gastropoda. The Queen Conch Strombus gigas is the largest among them to do so and symbiont acquisition is also horizontal and apparently required for metamorphosis (Ramos and Banaszak, 2014). While a large diversity of nudibranchs (mainly aeolids) are known to associate with Symbiodinium, there is a scarcity of larval experiments, possibly due to their typically restricted diet (Dionísio et al., 2013). The only exception is Berghia stephanieae, a species that stores Symbiodinium in dorsal extensions of the digestive diverticulum. Its lecithotrophic veliger larvae go through metamorphosis in the absence of Symbiodinium (Carroll and Kempf, 1990; Kempf, 1991), but recent studies suggest that this species does not engage in a mutualistic relationship (Mies et al., this thesis chapter 2). While nudibranchs acquire symbionts horizontally (Loh et al., 2006; Burghardt and Wägele, 2014; Ahmadian et al., 2016), a case of vertical transmission has been recently reported (Wecker et al., 2015).

\section{Symbiodinium clades}

Symbiodinium dinoflagellates may be found in two different life stages, a planktonic and free-living zoospore or a symbiotic and non-motile coccoid cyst (Freudenthal, 1962; Schoenberg and Trench, 1980; Stat et al., 2006). Thus, by presenting a free-living stage, the mutualistic association is not obligate for Symbiodinium. Based on ribosomal, plastid and mitochondrial phylogenies, they are divided in nine clades (A-I, Fig. 1) and 
many subclades (Rowan and Powers, 1991; LaJeunesse, 2001; Pochon et al., 2014). Species-level diversity is still being assessed and many new strains have been described recently (LaJeunesse et al., 2012; Hume et al., 2015; Lee et al., 2015), with probably more than one hundred extant species (LaJeunesse, 2001). The higher diversity is found within clade $\mathrm{C}$, that dominates Indo-Pacific coral reefs and is also one of the most abundant clades in the Atlantic (LaJeunesse, 2005). Host species tend to associate with a single Symbiodinium strain (Goulet, 2006), but multiple clades may be found within a single host specimen (Rowan and Powers, 1991; Carlos et al., 2000; Baker, 2003). Symbiodinium strain is a relevant factor for holobiont fitness, in both adult and larval stages (Schwarz et al., 1999; Mieog et al., 2009; Mies et al., this thesis chapter 4). While it has been reported that there is host life stage-specificity for symbiont strain, as juvenile and adult acroporid corals actively associate with different clades (Abrego et $a l ., 2009)$, there is no life-stage specificity reported for larval stages yet.

\section{Symbiont acquisition and larval response}

Animal larvae acquire symbionts from different sources, but mainly from the water column and sediment (Adams et al., 2009; Cumbo et al., 2012). The amount of Symbiodinium cells is highly variable among species and may vary according to environmental conditions. For acroporid corals Cumbo et al. (2012) report less than 10 symbiont cells acquired by larvae, while Harii et al. (2009) registered an average of 5060 symbiont cells, but with high variability. In another study, Mies et al. (this thesis chapter 3) report about 30 cells for giant clam and nudibranch larvae and more than 100 for coral larvae.

Metazoan hosts are able to select Symbiodinium strains through post-phagocytic recognition mechanisms involving lectin/glycan interactions (Koike et al., 2004; WoodCharlson et al., 2006; Fransolet et al., 2012). These mechanisms are also active during larval development and desired strains are kept while undesired ones suffer apoptosis (Dunn and Weis, 2009). Other experiments also show that coral (Bay et al., 2011) and gastropod (Ramos and Banaszak, 2014) larvae actively select symbionts. However, there are reports that coral larvae may have no preference for different symbiont strains (Cumbo et al., 2012). In a study testing the offer of a homologous and two heterologous 


\section{Host taxa}

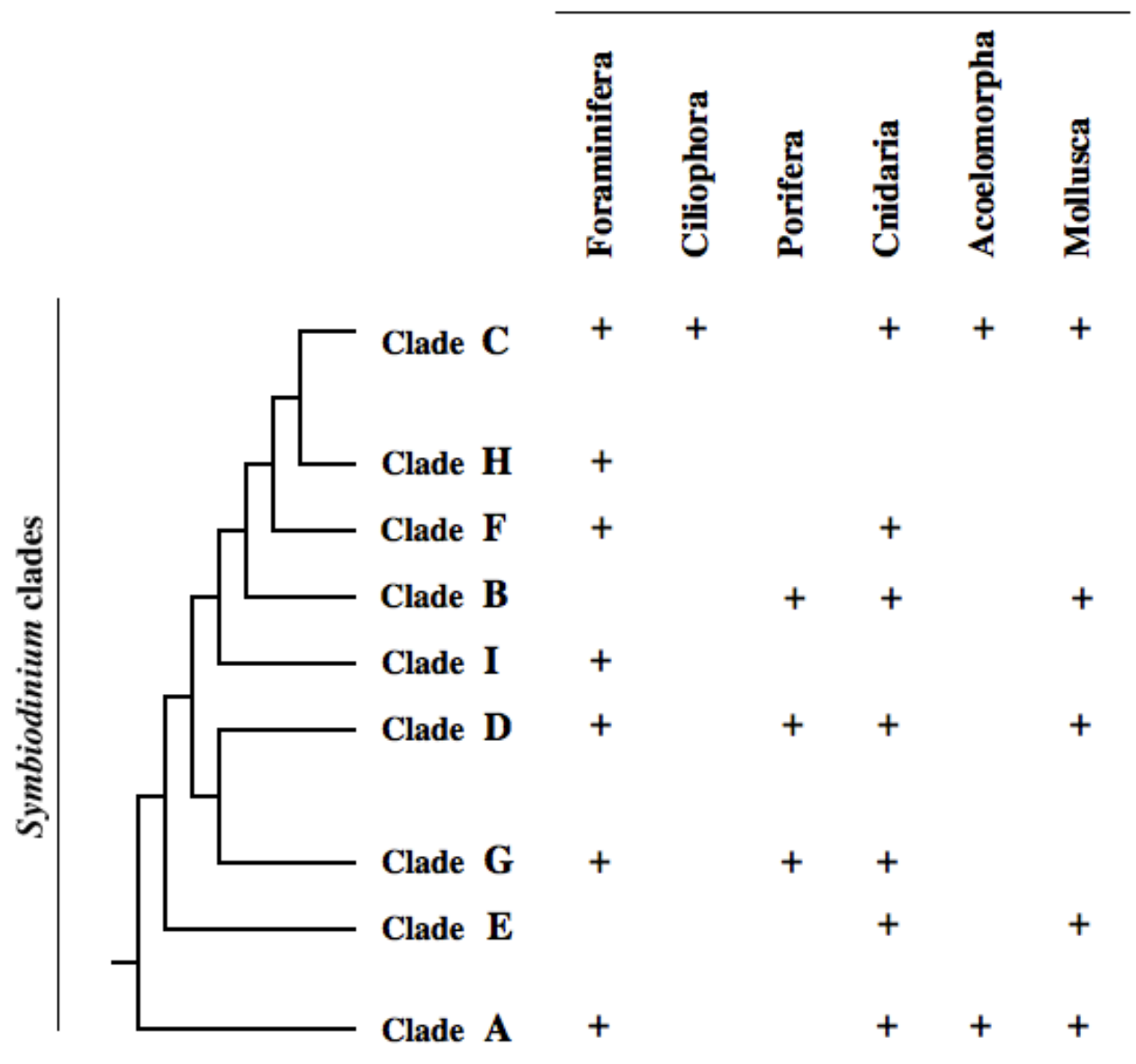

Fig. 1 Relationship between Symbiodinium clades (based on a multigene phylogeny - see Pochon et al., 2014) and their distribution in host taxa according to Stat et al. (2006); Barneah et al. (2007b) and Pochon et al. (2014).

strains to Fungia scutaria larvae, there was no statistical difference in acquisition among strains, except for one of the heterologous that had significantly lower acquisition (Rodriguez-Lanetty et al., 2004). Interestingly, homologous strains have been shown to distribute differently in larval tissues than heterologous strains (Rodriguez-Lanetty et al., 2006), and it has also been reported that homologous symbionts establish a more benefitting symbiosis (Trench et al., 1981; Schwarz et al., 1999; Dunn and Weis, 2009). However, Mies et al. (this thesis chapters 3 and 4) found no differences in survival in coral, nudibranch and giant clam larvae associated with both homologous and heterologous Symbiodinium clades.

The presence of symbionts in larval tissues may significantly contribute to its development. Giant clam larvae infected with Symbiodinium grow significantly larger than aposymbiotic larvae (Fitt et al., 1986; Mies et al., 2012) and F. scutaria larvae settle earlier in the presence of symbionts (Schwarz et al., 1999). However, higher 
growth not always suggests the establishment of symbiosis as some coral larvae have been shown to digest the symbionts (Titlyanov et al., 1998).

\section{Biochemical and molecular relationship}

The metabolite exchange between Symbiodinium and its adult host has been extensively documented. The host supplies the symbiont with $\mathrm{CO}_{2}$ and substrates for cellular synthesis such as nitrogen and phosphorus (Trench, 1979; Allemand et al., 1998; Leggat et al., 2003; Weis et al., 2008). In turn, the symbiont supplies the host with more than $90 \%$ of its metabolic requirement, in the form of organic compounds including glucose, glycerol, fatty acids and amino acids (Muscatine, 1990; Grant et al., 1997; Papina et al., 2003; Burriesci et al., 2012). But very little is known about the metabolite exchange between Symbiodinium and metazoan larvae. The only study confirming metabolite exchange is perhaps the one by Kopp et al., (2016), which shows that labeled ${ }^{13} \mathrm{C}$ and ${ }^{15} \mathrm{~N}$ are translocated from symbiont to Pocillopora damicornis larvae. However, that same study found that these compounds contribute insignificantly to the larval nutrition. Other reports show that Symbiodinium clades A and C associated with coral and giant clam larvae produce a higher amount of the fatty acid DHA (docosapentaenoic acid, 22:6w3 - see Mies et al., this thesis chapter 3) and that Symbiodinium associated with giant clam larvae express a glycerol-synthesizing gene (Mies et al., 2017b), but in neither of those cases translocation was effectively confirmed.

One of the main issues hindering the better understanding of this relationship is the lack of molecular studies and information for Symbiodinium, also addressed in Leggat et al. (2011). The genomes for clades A, B and F (Shoguchi et al., 2013; Lin et al., 2015; Aranda et al., 2016), transcriptomes for clades A-D (Bayer et al., 2012; Ladner et al., 2012) and the plastid genome for clade B (Mungpakdee et al., 2014) have been sequenced in recent years, but further information, especially on metabolic pathways, is still warranted. However, a few experiments performed differential gene expression on coral larvae with and without symbionts, all of which reported undetectable or inconclusive differences (deBoer et al., 2007; Voolstra et al., 2009; Schnitzler and Weis, 2010). The exception and explanation comes from Mohamed et al. (2016), that reports that less than $3 \%$ of the host transcriptome is altered after exposure 
of Acropora digitifera planulae to Symbiodinium. While yet to be applied for larval studies, symbiosis-specific genes have been identified recently in the Aiptasia anemone (Bucher et al., 2016; Wolfowicz et al., 2016). From the symbiont perspective, apart from the identification of protein kinases that may be involved in the establishment of symbiosis (Rosic et al., 2014), a symbiosis-specific gene was identified in Symbiodinium clade A, an $\mathrm{H}^{+}$-ATPase (Bertucci et al., 2010). This gene is the only symbiosis-specific gene that had its expression verified in Symbiodinium associated with metazoan larvae (Mies et al., 2017b; this thesis chapter 2). The expression of this gene was confirmed in the veliger larvae of the giant clams Tridacna crocea and $T$. maxima and in the planula larvae of the hermatypic coral Mussismilia hispida, demonstrating that symbiosis is active.

\section{Environmental influence}

Climate change is having a significant impact on coral reef ecosystems, particularly because of ocean acidification and the rise in seawater temperature (Hoegh-Guldberg, 1999; Hughes et al., 2003; Pandolfi et al., 2003; Hoegh-Guldberg et al., 2007). However, while the effects of ocean acidification have been investigated in metazoan larvae (Nakamura et al., 2011; Waldbusser et al., 2013; Rivest and Hofmann, 2014), they are yet to be assessed on metazoan larva-Symbiodinium associations. Defined by the loss of Symbiodinium cells from host tissue (Brown, 1997; Hoegh-Guldberg, 1999; Fitt et al., 2001), the bleaching phenomenon is the main effect of the rise in seawater surface temperature and has been widely documented.

The bleaching threshold for coral reef larvae is usually between $28-30^{\circ} \mathrm{C}$ (Edmunds et al., 2005; Mieog et al., 2009), when the expression of heat-shock proteins and oxidative-stress genes becomes detectable (Rodriguez-Lanetty et al., 2009; Meyer et al., 2011). The findings in Mies et al. (this thesis chapter 4) show that coral and giant clam larvae bleach at $29^{\circ} \mathrm{C}$ and hardly survive past $32^{\circ} \mathrm{C}$. However, the highly-tolerant larvae of Pocillopora damicornis have been shown to withstand a temperature of $32^{\circ} \mathrm{C}$, despite losing the majority of its symbiont cells (Haryanti et al., 2015). The symbiont clade associated with the larvae may also influence bleaching intensity, as coral and giant clam larvae associated with Symbiodinium clades A and C bleach at lower rates than clades B, D, E and F (Mies et al., this thesis chapter 4). However, further 
investigation is required, especially for clade $\mathrm{D}$, which increases the adult host threshold and becomes dominant during bleaching events (Berkelmans and van Oppen, 2006; Jones et al., 2008; Mieog et al., 2009; Ladner et al., 2012).

While symbiont presence is generally perceived as positive for coral reef larvae development and fitness, under thermal stress it may have the opposite effect. High temperatures cause the symbionts to become a source of reactive oxygen species (ROS), which leads to significantly higher larval mortality (Weis, 2008; Baird et al., 2009; Yakovleva et al., 2009; Schnitzler et al., 2012). Some of the effects of ROS include DNA damage and higher rates of antioxidant activity (Yakovleva et al., 2009; Nesa et al., 2012).

\section{Is there a mutualism?}

Symbiosis is usually defined as the long-term interaction between two different organisms and mutualism is defined as a beneficial relationship for both parties. Considering all of the information given in the previous sections, it is questionable whether a mutualistic symbiosis is in place for most metazoan larva-Symbiodinium associations. According to Davy et al. (2012), the establishment of symbiosis between Symbiodinium and its host is a complex process that involves several steps: symbiont uptake, phagocytosis by host cells (in the case of intracellular relationship), function integration, symbiont reproduction and long-term persistence. Therefore, for hosts in their larval development, the establishment of symbiosis would have to follow the steps in Fig. 2, which include symbiont acquisition, transfer of symbionts from gut to endodermal tissue, metabolite exchange and symbiont reproduction and persistence.

The vast majority of experiments performed on larva-Symbiodinium associations only visually observed the acquisition of symbionts and no metabolite exchange was detected, which fails to meet the criteria above. Especially considering reports that some larvae may digest the symbionts (Titlyanov et al., 1998; Mies et al., this thesis chapters 2,3 and 4). There are several reports that come close to confirming the establishment of the mutualism, such as the transcriptional changes in coral larvae after symbiont exposure (Mohamed et al., 2016), although it is unclear if these changes are related to a mutualistic relationship or to the mere presence of a foreign algal body. The reports of higher production of fatty acids by Symbiodinium associated with coral and giant clam 
larvae (Mies et al., this thesis chapter 3) and increases in larval caloric content and competence due to symbiont presence (Ben-David-Zaslow and Benayahu, 1998) also suggest but do not prove metabolite exchange. Perhaps the most compelling evidence of symbiosis between metazoan larvae and Symbiodinium comes from Mies et al. (2017b, this thesis chapter 2) and Kopp et al. (2016), which show the expression of a symbiosisspecific gene by Symbiodinium associated with coral (Mussismilia hispida) and giant clam (Tridacna crocea and T. maxima) larvae and the transfer of labeled carbon and nitrogen from symbiont to coral planulae (Pocillopora damicornis), respectively.
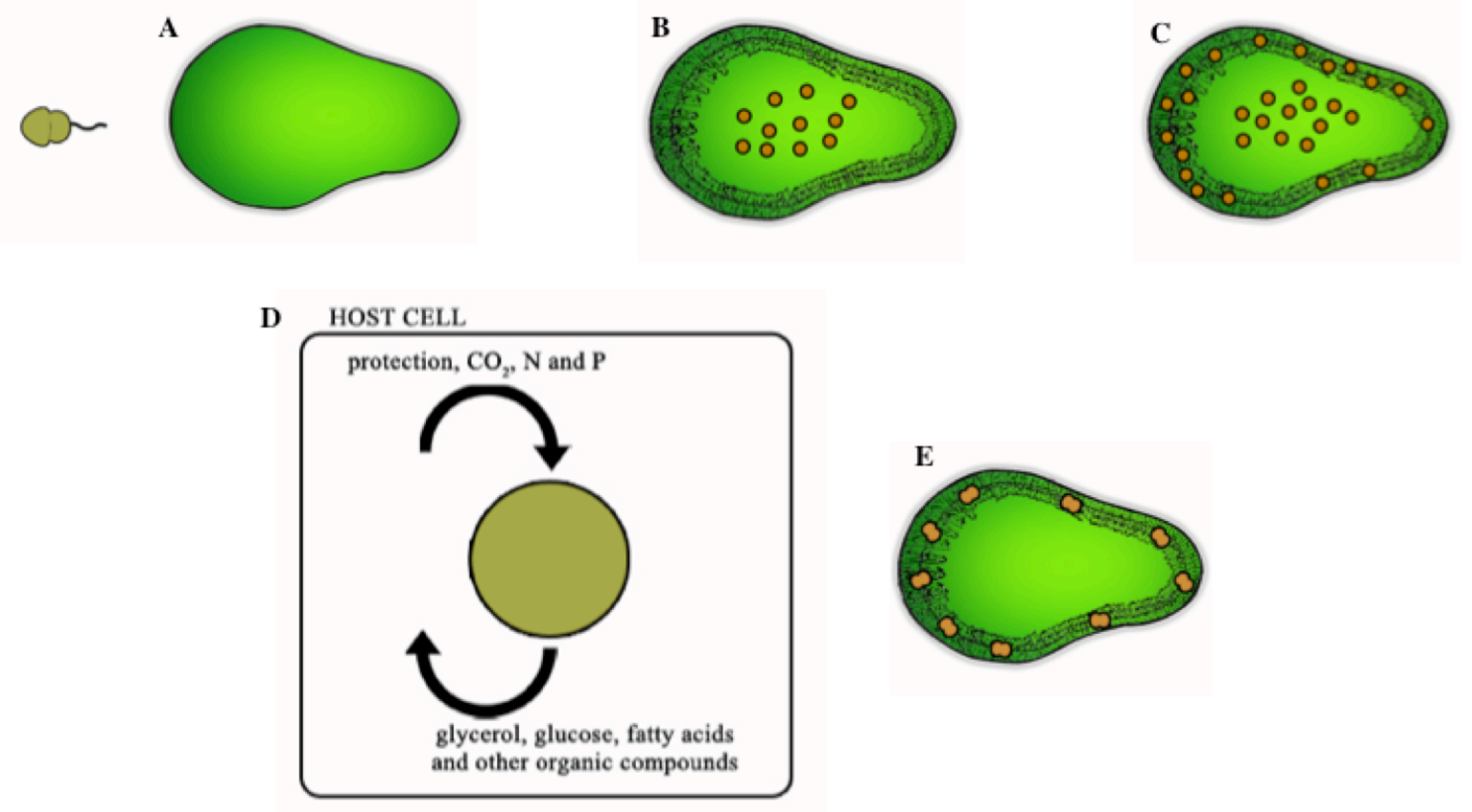

Fig. 2 Steps for the establishment of a mutualistic relationship between Symbiodinium and metazoan larvae, using a coral planula as example: A larval acquisition of free-living Symbiodinium zoospore, B symbiont inside gastrovascular vascular immediately after acquisition, $\mathbf{C}$ symbiont transfer to endodermal tissues, $\mathbf{D}$ metabolite/favor exchange, and $\mathbf{E}$ symbiont reproduction and long-term persistence.

This review provides an analysis on the relationship between Symbiodinium and metazoan larvae. The information compiled and discussed shows that symbiont presence may be imperative for the larval development and recruitment of certain host groups, while symbiont identity may improve larval fitness and better withstand thermal variations. However, for most cases investigated, the mutualistic relationship cannot be confirmed. The information presented may also be used for the improvement of aquaculture protocols, as well as provide insights for programs related to coral reef conservation and mitigation of climate change impacts. 


\section{Acknowledgements}

We would like to thank Arthur Güth and Linda Waters for their important inputs that greatly contributed to the production of this manuscript, and Juliana Ali for the illustrations.

\section{Author contributions}

M.M. and P.Y.G.S. wrote the manuscript. 


\title{
CHAPTER TWO
}

\section{Expression of a symbiosis-specific gene in Symbiodinium clade A1 associated with coral, nudibranch and giant clam larvae}

\author{
Mies, M. ${ }^{12^{*}}$; Sumida, P. Y. G. ${ }^{1}$; Voolstra, C. R. ${ }^{3}$; Castro, C. B. ${ }^{4,5}$; Pires, D. O. ${ }^{4,5}$; \\ Calderón, E. N. ${ }^{5,6} \&$ Van Sluys, M. A. ${ }^{2}$
}

${ }^{I}$ Oceanographic Institute, University of São Paulo. Praça do Oceanográfico, 191 - 05508-120 São Paulo, SP - Brazil.

${ }^{2}$ Institute of Biosciences, University of São Paulo. Rua do Matão, 277 - 05508-090 São Paulo, SP - Brazil.

${ }^{3}$ Red Sea Research Center, Division of Biological and Environmental Science and Engineering, King Abdullah University of Science and Technology. 23955-6900 Thuwal - Saudi Arabia.

${ }^{4}$ Museu Nacional, Universidade Federal do Rio de Janeiro. Quinta da Boa Vista, s/n - 20940040 Rio de Janeiro, $R J$ - Brazil.

${ }^{5}$ Instituto Coral Vivo. Rua dos Coqueiros, 87 - 45807-000 Santa Cruz Cabrália, BA - Brazil.

${ }^{6}$ Núcleo em Ecologia e Desenvolvimento Socioambiental de Macaé, Universidade Federal do Rio de Janeiro. Av São José do Barreto, 764 - 27965-045 Macaé, RJ - Brazil.

* Corresponding author: miguel.mies@usp.br

\begin{abstract}
Coral reefs are highly diverse marine environments. Such biodiversity is supported by the primary production performed by dinoflagellates of the genus Symbiodinium. These dinoflagellates are found in a mutualistic symbiosis with multiple animal phyla. However, very little is known about the establishment of this symbiosis and whether it initiates during host larval development. To address this question, we monitored the expression of a putative symbiosis-specific gene $\left(\mathrm{H}^{+}\right.$-ATPase) in Symbiodinium A1 ex hospite and in association with larvae of a scleractinian coral (Mussismilia hispida), a nudibranch (Berghia stephanieae) and a giant clam (Tridacna crocea). We acquired broodstock for each invertebrate host, induced spawning and collected the larvae, which were placed in plankton kreisels. Symbiodinium A1 cells were offered and larvae samples taken for each host at $0,12,24,48$ and $72 \mathrm{~h}$ after symbiont addition. Control samples such as free-living Symbiodinium and broodstock tissue containing symbionts for each host were collected. Total RNA extraction and RT-PCR were performed and amplified products cloned and sequenced. The $\mathrm{H}^{+}$-ATPase was found expressed in coral and giant clam larvae, but not for nudibranch larvae, that were digesting the symbionts. Broodstock tissue for coral and giant clam also expressed $\mathrm{H}^{+}$-ATPase, but not the
\end{abstract}


nudibranch tissue sample. Our results of the $\mathrm{H}^{+}$-ATPase expression suggest that symbiosis between Symbiodinium and M. hispida and T. crocea is established during host larval development. Conversely, case of B. stephanieae, the absence of the $\mathrm{H}^{+}$ATPase expression show that Symbiodinium is ingested, but no mutualistic relationships are established. In conclusion, our study supports the utilization of $\mathrm{H}^{+}$-ATPase gene expression as a marker for assessing Symbiodinium-invertebrate relationships with applications for the differentiation of symbiotic and non-symbiotic associations.

Keywords: zooxanthellae, Tridacna, Scleractinia, sea slug, larval ecology, ATPase

\section{Introduction}

Coral reefs are marine coastal environments found in tropical areas, noted for their remarkable biodiversity (Sheppard et al., 2009). This diversity is supported by the complexity of habitats created by the $\mathrm{CaCO}_{3}$ structure produced by reef-building corals (Kleypas and Yates, 2009) and by the high primary production performed by symbiotic dinoflagellates, also called zooxanthellae (Cesar, 2000; Hughes et al., 2003; Pandolfi et al., 2003). These dinoflagellates (genus Symbiodinium) are found in an endosymbiotic association with multiple metazoan and protist phyla (Stat et al., 2006), being harbored inside the host tissues at high densities, typically $10^{10}$ cells per $\mathrm{m}^{2}$ of coral reef (Baker, 2003).

Before the widespread availability of mainstream molecular biology techniques, a single species of zooxanthella had been described (Symbiodinium microadriaticum) and considered pandemic (Freudenthal, 1962; Taylor, 1974). However, through phylogenetic analyses combining ribosomal (nuclear), chloroplast and mitochondrial genes (Rowan and Powers, 1991; LaJeunesse, 2001; Pochon et al., 2014), Symbiodinium dinoflagellates have been proposed to be categorized in nine clades, A-I (Pochon and Gates, 2010). Current efforts are concentrating on the formal description of species within the clades (LaJeunesse et al., 2012; Hume et al., 2015; Lee et al., 2015). Each clade tends to associate with a particular selection of hosts (Baker, 2003; Coffroth and Santos, 2005; Goulet, 2006), and in cases of acquisition of heterologous clades, the host typically displays reduced fitness and growth (Weis et al., 2001; RodriguezLanetty, 2003).

The symbiosis between Symbiodinium and their hosts is mutualistic. In exchange for protection, $\mathrm{CO}_{2}$, nitrogen and phosphorus (Trench, 1979; Allemand et al., 1998; Leggat et al., 2003), Symbiodinium supplies the host with several organic 
compounds, including glycerol, glucose, fatty acids and amino acids (Grant et al., 1997), which may contribute to more than $90 \%$ of metabolic requirements of the host (Muscatine, 1990). While this metabolite exchange is very well researched for adult hosts, there is scarcity of information for the relationship between Symbiodinium and hosts still in their larval stages. The majority of zooxanthellate organisms acquire their symbionts horizontally (Fitt et al., 1986; Harrison and Wallace, 1990; Baird et al., 2009), but it is still unknown when and if metabolite exchange initiates during larval development, which may have a crucial impact on the recruitment of coral reef organisms. In addition to these considerations, metabolite exchange and molecular signals are important to ascertain whether a mutualism is in place. Recent studies have sequenced genes in cnidarians that may be symbiosis-specific markers (Baumgarten et al., 2015; Mohamed et al., 2016; Wolfowicz et al., 2016), but are yet to be tested. While Symbiodinium genomes for clades A, B and F have been sequenced recently (Shoguchi et al., 2013; Lin et al., 2015; Aranda et al., 2016), only a single symbiosis-specific marker has been suggested to date. This marker is the $\mathrm{H}^{+}$-ATPase, a proton pump that transports cations across the cell membrane (Møller et al., 1996; Kühlbrandt, 2004) and that is only expressed by Symbiodinium engaged in the mutualistic symbiosis (Bertucci et al., 2010). At present, this gene has only been characterized for Symbiodinium A1 (Bertucci et al., 2010). Also, it seems to be little conserved among clades, with a variation in the amount and size of introns, making it more difficult to detect and amplify for Symbiodinium species belonging to other clades (M. Mies, unpublished data).

In order to better understand the symbiotic relationship between Symbiodinium and coral reef larvae and to assess the general suitability of $\mathrm{H}^{+}$-ATPase as a symbiosis marker, we investigated $\mathrm{H}^{+}$-ATPase expression by Symbiodinium when associated with larvae of three different hosts: i) Mussismilia hispida, a scleractinian coral; ii) Berghia stephanieae, a nudibranch and iii) Tridacna crocea, a giant clam. By investigating these relationships we hope to not only determine if and when the mutualistic relationship between these organisms is established during larval development, but also to increase our current understanding of coral reef larval ecology, with potential implications for recruitment and dispersal. 


\section{Materials and methods}

The experiment was designed with the purpose of amplifying the $\mathrm{H}^{+}$-ATPase in Symbiodinium associated with coral, slug and clam larvae. Therefore, we cultured Symbiodinium, spawned and cultured the offspring of the three hosts, offered the cultured Symbiodinium, took samples periodically, performed RNA extraction, RTPCR, cloning and sequencing.

Symbiodinium culture

Symbiodinium cells (ITS2 clade A1) were cultured using the f/2 medium (Guillard and Ryther, 1962), at a temperature of $23^{\circ} \mathrm{C}$ and a photon flux of $100 \mu \mathrm{E} \mathrm{m}^{-2} \mathrm{~s}^{-1}$ with a photoperiod of 12L:12D. The antibiotics penicillin and streptomycin were added together with the culture medium, at a final concentration of 1.0 and $0.5 \mathrm{~g} \mathrm{~L}^{-1}$, respectively.

\section{Broodstock maintenance and spawning}

The Symbiodinium hosts selected for this experiment (Table 1) were Mussismilia hispida, a reef-building coral endemic to Brazil with a latitudinal distribution of 2,500 km (Castro and Pires, 2001); the stenophagous nudibranch Berghia stephanieae (formerly known as Aeolidiella stephanieae and often mistaken for Berghia verrucicornis) that feeds exclusively on zooxanthellate anemones of the genus Aiptasia (Carroll and Kempf, 1990); and the smallest species of giant clams, Tridacna crocea. All of these hosts naturally house Symbiodinium strains belonging to clade A and all of them acquire symbionts horizontally (Carroll and Kempf, 1990; Neves and Pires, 2002; Mies et al., 2012). All organisms were kept under conditions that simulated tropical reef waters, i.e., temperature at $27^{\circ} \mathrm{C}$, specific gravity at $1,024 \mathrm{~kg} \mathrm{~m}^{-3}$ and nutrient concentrations near zero. Thirty $M$. hispida colonies $(17.5 \pm 3.5 \mathrm{~cm}$ in approximate diameter) were collected at the Recife de Fora ( $\left.16^{\circ} 25^{\prime} \mathrm{S}, 38^{\circ} 59^{\prime} \mathrm{W}\right)$, near the Abrolhos Reefs in northeastern Brazil. Colonies were kept in semi-closed nursery tanks and naturally spawned gamete bundles containing both spermatozoa and oocytes were 
Table 1 Ecological aspects of the three Symbiodinium hosts used in this experiment, including their range distribution, spawning mode, larval size, and mode, stages and total duration of larval development (according to Carroll and Kempf, 1990; Mies and Sumida, 2012; Pires et al., 2016). Larval stages in bold denote the stages used in this experiment, at 4,10 and 3 days postfertilization, respectively.

\begin{tabular}{lcccccc}
\hline Host organism & $\begin{array}{c}\text { Distri- } \\
\text { bution }\end{array}$ & $\begin{array}{c}\text { Spawning } \\
\text { mode }\end{array}$ & $\begin{array}{c}\text { Larvae } \\
\text { size at } \\
\text { hatching } \\
(\mu \mathrm{m})\end{array}$ & $\begin{array}{c}\text { Larval } \\
\text { development } \\
\text { mode }\end{array}$ & $\begin{array}{c}\text { Larval } \\
\text { development } \\
\text { stages }\end{array}$ & $\begin{array}{c}\text { Larval } \\
\text { development } \\
\text { duration }\end{array}$ \\
\hline $\begin{array}{l}\text { Mussismilia hispida } \\
\text { (Scleractinia) }\end{array}$ & $\begin{array}{c}\text { Tropical } \\
\text { Brazil }\end{array}$ & $\begin{array}{c}\text { broadcast } \\
\text { spawner }\end{array}$ & $\approx 300$ & lecithotrophic & planula & $\approx 12$ days \\
$\begin{array}{l}\text { Berghia stephanieae } \\
\text { (Gastropoda) }\end{array}$ & $\begin{array}{c}\text { Gulf of } \\
\text { Mexico }\end{array}$ & $\begin{array}{c}\text { benthic } \\
\text { spawner }\end{array}$ & $\approx 200$ & $\begin{array}{c}\text { facultative } \\
\text { planktotrophic }\end{array}$ & veliger & $1-2$ days \\
$\begin{array}{l}\text { Tridacna crocea } \\
\text { (Bivalvia) }\end{array}$ & $\begin{array}{c}\text { Tropical } \\
\text { Indo- } \\
\text { Pacific }\end{array}$ & $\begin{array}{c}\text { broadcast } \\
\text { spawner }\end{array}$ & $\approx 95$ & planktotrophic & $\begin{array}{c}\text { trochophore, } \\
\text { veliger and } \\
\text { pediveliger }\end{array}$ & $\approx 17$ days \\
\hline
\end{tabular}

collected immediately after release. Bundles were dispersed and oocytes fertilized in 60 L tubs and kept for four days until planulae had open digestive tracts. Water changes of 90\% were performed daily and strong aeration was provided in order to keep the extremely buoyant eggs from becoming trapped in the surface tension. One hundred thirty broodstock individuals of $B$. stephanieae $(1.7 \pm 0.3 \mathrm{~cm}$ in length) were kept in two $60 \mathrm{~L}$ black round tubs in a recirculating aquaria system of $250 \mathrm{~L}$. They were fed 250 individuals of the glass anemone, Aiptasia sp. (harboring Symbiodinium clade A1) and egg masses spawned overnight were collected in the next morning. Embryos were then kept for ten days under strong aeration in order to stimulate the release of veliger larvae (Carroll and Kempf, 1990). Finally, 10 T. crocea broodstock individuals (7.6 \pm $0.9 \mathrm{~cm}$ in shell length) were maintained in a $350-\mathrm{L}$ recirculating system for three months in order to stimulate gamete production (Beckvar, 1981; Mies and Sumida, 2012). They were then induced to spawn with an intragonadal injection of $1.0 \mathrm{~mL}$ of a serotonin (5-hydroxytryptamine, $1.0 \mathrm{~g} \mathrm{~L}^{-1}$ ) solution (Braley, 1985; Alcazar et al., 1987; Mies et al., 2013). Fertilization was performed according to Heslinga et al. (1990) and eggs and, subsequently, trochophore larvae were kept in $60 \mathrm{~L}$ black round tubs for three days until all larvae attained the veliger stage. Water changes of $50 \%$ were performed daily. 
Larval cultures, Symbiodinium offering and sampling

For each host, larvae were placed in three (replicates) 1.2-L plankton kreisels kept in water baths at $27^{\circ} \mathrm{C}$. Mussismilia hispida planulae were stocked at 0.8 larva $\mathrm{mL}^{-1}, B$. stephanieae veligers at $1.0 \mathrm{~mL}^{-1}$ and $T$. crocea veligers at $2.0 \mathrm{~mL}^{-1}$. Symbiodinium A1 was then offered at a final concentration of $10^{3}$ cells $\mathrm{mL}^{-1}$ to all kreisels. At $11 \mathrm{~h}$ postsymbiont offering (PSO), a water change of $100 \%$ was performed in all kreisels in order to remove Symbiodinium cells that had not been acquired. Symbiont acquisition was recorded at this point. Samples of 50, 50 and 250 larvae were taken for M. hispida, B. stephanieae and T. crocea, respectively, at 0, 12, 24, 48 and $72 \mathrm{~h}$ PSO. As a positive control for the expression of $\mathrm{H}^{+}$-ATPase, tissue (containing symbionts) was retrieved from adult individuals of each host. To confirm that cultured (free-living) Symbiodinium do not express $\mathrm{H}^{+}$-ATPase, a sample containing $1.0 \times 10^{6}$ cells was obtained.

\section{Primer design}

In order to confirm the identity of the Symbiodinium culture we amplified the internal transcribed spacer 2 (ITS2), using primers designed by LaJeunesse and Trench (2000). Two Symbiodinium genes were targeted for this experiment, $\mathrm{H}^{+}$-ATPase (Enzyme Commission number 3.6.3.6) and RuBisCO (Ribulose-1,5-bisphosphate carboxylase oxygenase, EC number 4.1.1.39), with the latter chosen as a positive control. Primers for $\mathrm{H}^{+}$-ATPase (5'-GCACTTCTTGGGCTTGCTGC-3' and 5' ATCTTCCGGGACTCCACCAC-3') were designed in adjacent regions of two conserved amino acids motifs that are diagnostic for this protein (Meade et al., 2000), the ATP phosphorylation site (DKTGTLT) and the ATP binding site (TGDGVND). The design was based on conserved regions from the alignment of several sequences obtained from transcriptomes and expressed sequence tags of multiple Symbiodinium clades and other dinoflagellates (Hackett et al., 2005; Patron et al., 2005; KarakoLampert et al., 2006; Leggat et al., 2007; Toulza et al., 2010; Bayer et al., 2012; Ladner et al., 2012; Baumgarten et al., 2013; Rosic et al., 2014). The RuBisCO primers (5'ACCGGCGTGGGCAAGCTGTTCTCT-3' and 5'-TGGGAGTGGTCTGCTTCATG3') were taken from Bertucci et al. (2010). 


\section{$R N A$ extraction and $R T-P C R$ reaction}

Total RNA was extracted from all samples, including the cultured Symbiodinium and the tissues from coral, nudibranch and giant clam broodstock. Samples were macerated with a mortar and a pestle, and TriReagent (Ambion) was used for the extraction with modifications suggested in Rosic and Hoegh-Guldberg (2010). Extracted RNA was then treated with the Turbo-DNA-Free kit (Ambion) and the cDNA was generated using the SuperScript First Strand Synthesis III kit (Invitrogen). Approximately 50 ng of cDNA was used in the RT-PCR in a reaction volume of $25 \mu \mathrm{L}$, with final concentrations of 2.0 $\mathrm{mM} \mathrm{MgCl}{ }_{2}, 0.2 \mathrm{mM}$ dNTPs, $0.15 \mathrm{mM}$ for both forward and reverse primers and 0.04 units $\mu \mathrm{L}^{-1}$ of GoTaq DNA polymerase (Promega). Cycling conditions for $\mathrm{H}^{+}$-ATPase and RuBisCO were the following: $3 \mathrm{~min}$ at $94^{\circ} \mathrm{C}, 35$ cycles of $1 \mathrm{~min}$ at $94^{\circ} \mathrm{C}, 1 \mathrm{~min}$ at $54^{\circ} \mathrm{C}$ and $1.5 \mathrm{~min}$ at $72^{\circ} \mathrm{C}$ and termination at $72^{\circ} \mathrm{C}$ for $5 \mathrm{~min}$. Cycling conditions for the ITS2 were according to LaJeunesse and Trench (2000).

\section{Cloning and sequencing}

The amplicons produced were separated on $0.8 \%$ agarose, band-purified using the Nucleospin Extract II kit (Macherey-Nagel) and ligated into pGEM T-Easy vector (Promega). Vectors were transformed into electrocompetent cells (DH10B) according to standard practices described in Sambrook et al. (1989). Plasmid minipreparations, also according to Sambrook et al. (1989), were performed for each RT-PCR reaction and sequenced on a $3130 \mathrm{XI}$ sequencer using $\mathrm{T} 7$ vector primer.

\section{Phylogenetic analysis}

Nucleotide sequences related to both $\mathrm{H}^{+}$-ATPase and RuBisCO sequences produced in this experiment were retrieved from the National Center for Biotechnology Information (NCBI) using the BLAST algorithm (Sayers et al., 2012). Maximum-likelihood phylogenies for both genes were generated in MEGA5 (Tamura et al., 2011) using the optimal model of nucleotide substitution (default settings) and a bootstrap of 1,000 replicates. 


\section{Results}

More than $99 \%$ of all host larvae acquired symbionts. The number of symbionts acquired varied greatly among hosts. Symbiont acquisition per planula larva of $M$. hispida was $194.5 \pm 31.6$ cells, while B. stephanieae and T. crocea veligers acquired $19.2 \pm 5.0$ and $36.6 \pm 6.5$ cells, respectively. Tridacna crocea veligers kept the symbionts in the digestive tract throughout the duration of the experiment, while $M$. hispida planulae seemed to move them from the gastrovascular cavity to different areas in the endoderm (Fig. 1). Surprisingly, stereomicroscope observations showed that $B$. stephanieae larvae digested the symbionts and did not move them to specialized tissues or cells. Many B. stephanieae individuals underwent metamorphosis after $48 \mathrm{~h}$ PSO and all of them had become juveniles at $72 \mathrm{~h}$ PSO.

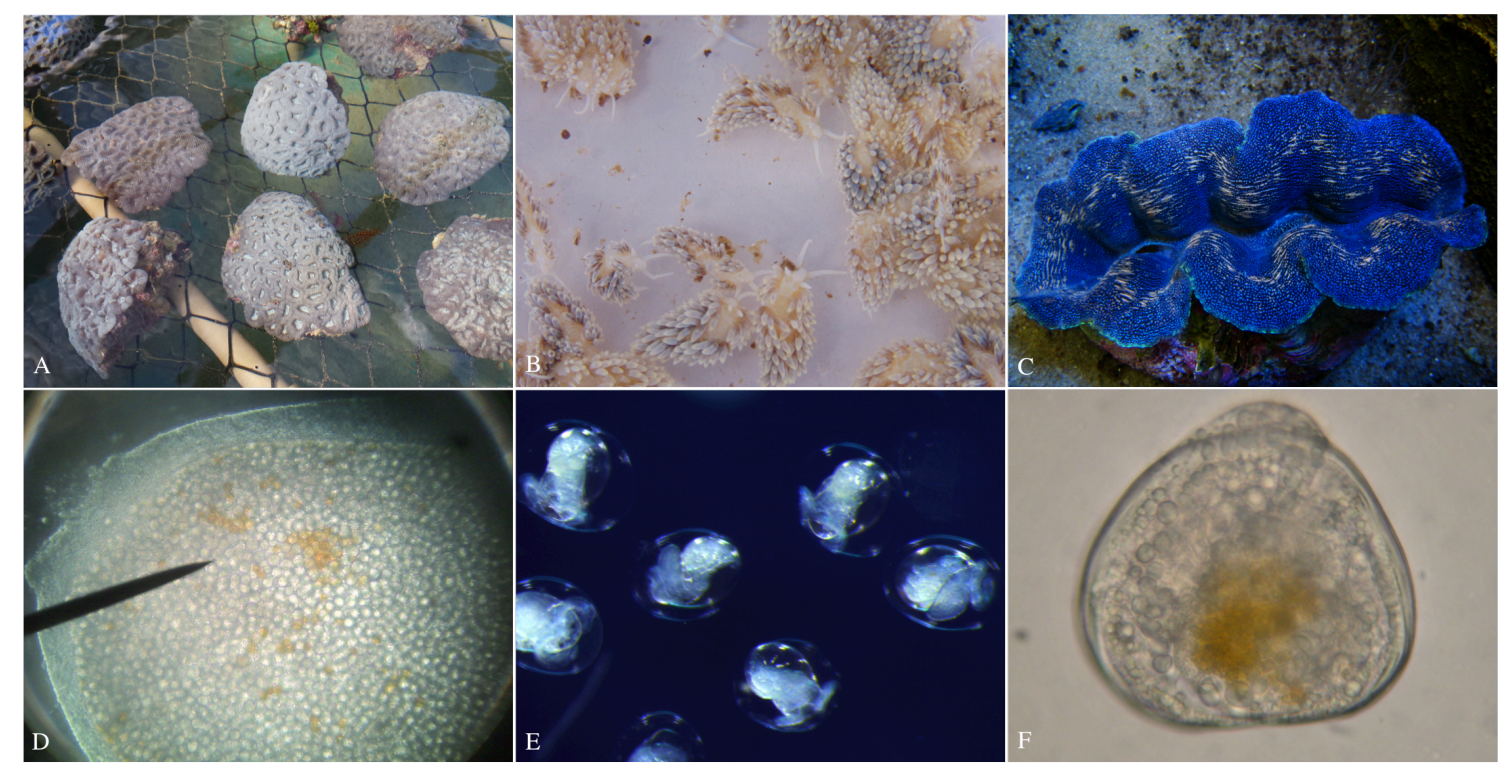

Fig. 1 Host broodstock and larvae used in the experiment. A Mussismilia hispida colonies collected at Recife de Fora, B Berghia stephanieae spawning individuals (note brownish area in the cerata, harboring Symbiodinium cells captured from the anemone Aiptasia sp.), C Tridacna crocea broodstock clam, D M. hispida planula after acquiring multiple Symbiodinium A1 cells, E B. stephanieae veliger larvae immediately before hatching and $\mathbf{F} T$. crocea veliger larva with Symbiodinium A1 cells inside the digestive tract.

The ITS2 amplification confirmed that the Symbidiodinium cells belonged to clade A1. The amplicons produced for $\mathrm{H}^{+}$-ATPase and $\mathrm{RuBisCO}$ genes had a size of 460 and $430 \mathrm{bp}$, respectively (GenBank accession numbers KY483989-997). The BLAST searches and phylogenetic trees (Fig. 2) confirmed that the sequences obtained belong to Symbiodinium A1. All $\mathrm{H}^{+}$-ATPase and RuBisCO sequences obtained were 99 
and $100 \%$ identical in pairwise comparisons, respectively. Phylogenetic analyses (Fig. 2) and BLAST results confirm that the targeted gene were amplified and belonged to Symbiodinium A1. The $\mathrm{H}^{+}$-ATPase sequences were $99 \%$ identical to Symbiodinium A1 (GenBank accession number FJ807389) and RuBisCO sequences were 95\% identical to Symbiodinium (GenBank accession number JX465541).

Free-living Symbiodinium, as expected, did not express the $\mathrm{H}^{+}$-ATPase. Broodstock tissue containing symbionts from both $M$. hispida and T. crocea did express the $\mathrm{H}^{+}$-ATPase, while tissue from $B$. stephanieae did not. Out of the three replicated larval cultures for $M$. hispida, the $\mathrm{H}^{+}$-ATPase gene was expressed in only one replicate, at $72 \mathrm{~h}$ PSO (Table 2). This gene was not expressed by any B. stephaniae larval replicates, at any time. For T. crocea, one of the replicates expressed the $\mathrm{H}^{+}$-ATPase at 24, 48 and $72 \mathrm{~h}$ PSO, the second replicate only at 24 and $72 \mathrm{~h}$ PSO and the third replicate did not express the gene. The RuBisCO gene was expressed for all broodstock tissue and larval samples, as well as for the free-living Symbiodinium in culture.

\section{Discussion}

The establishment of a mutualistic symbiosis is a process that requires the successful completion of many steps, such as symbiont acquisition, transfer to specialized cells/tissues, metabolite and/or favor exchange, and long-term persistence (Davy et al., 2012). However, very little is known about the biochemical and molecular mechanisms involved in the establishment of this relationship. The only difference reported is the expression of $\mathrm{H}^{+}$-ATPase, a symbiosis-specific gene (Bertucci et al., 2010). Although a number of studies have investigated differential expression in marine invertebrate hosts with and without Symbiodinium (deBoer et al., 2007; Voolstra et al., 2009a; Voolstra et al., 2009b; Polato et al., 2010; Schnitzler and Weis, 2010; Wolfowicz et al., 2016), few have attempted to suggest symbiosis marker genes that can be reliably used to assess symbiotic states. The protein coded for by the $\mathrm{H}^{+}$-ATPase is responsible for several reactions, particularly in generating protons gradients across the plasma membrane and dehydrating $\mathrm{HCO}_{3}{ }^{-}$(Goiran et al., 1996; Allemand et al., 1998; Kühlbrandt, 2004). This gene is also present in other photosynthetic eukaryotes such as 


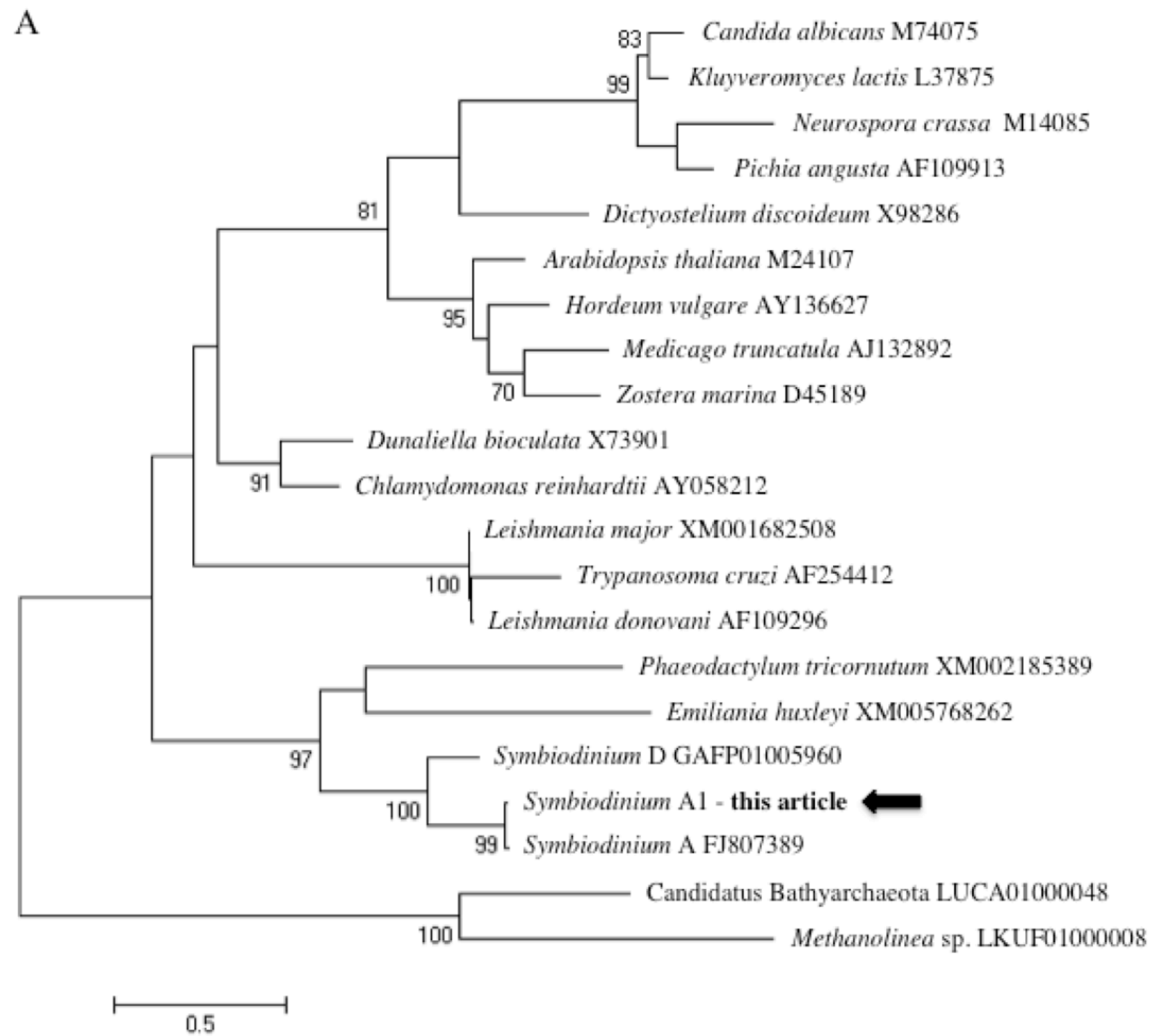

B

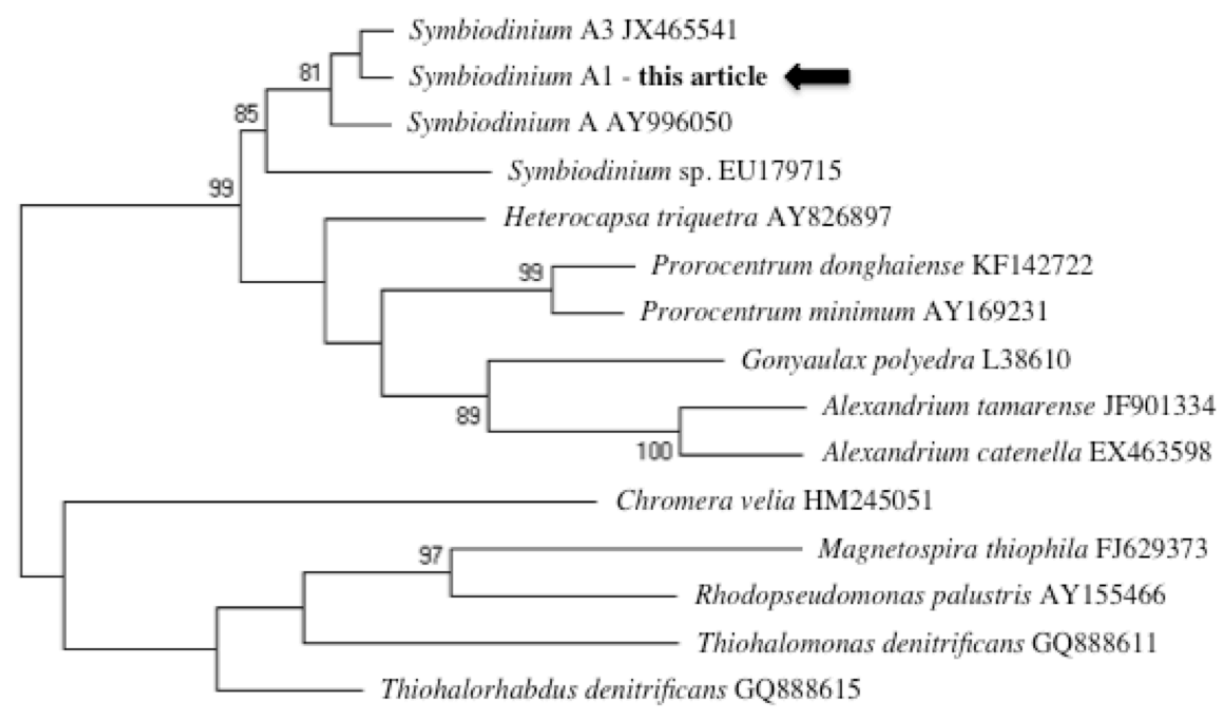

$\longmapsto$

Fig. 2 Phylogeny of (A) $\mathrm{H}^{+}$-ATPase and (B) RuBisCO genes of Symbiodinium A1 in this experiment. Trees were constructed using maximum likelihood analysis and 1,000 bootstrap replicates; only values above 70 are shown. Accession numbers are from the National Center of Biotechnology Information (NCBI) database. 
Table 2 Expression of $\mathrm{H}^{+}$-ATPase by Symbiodinium A1 acquired by Mussismilia hispida (scleractinian coral), Berghia stephanieae (nudibranch) and Tridacna crocea (giant clam) larvae over $72 \mathrm{~h}$ after acquisition. Expression for cultured Symbiodinium A1 (free-living) and tissue of host broodstock was also monitored. All samples exhibited expression of RuBisCO (positive control).

\begin{tabular}{lcccccc}
\hline Sample & $\begin{array}{c}\text { Control } \\
\text { samples }\end{array}$ & $0 \mathrm{~h}$ & $12 \mathrm{~h}$ & $24 \mathrm{~h}$ & $48 \mathrm{~h}$ & $72 \mathrm{~h}$ \\
\hline Symbiodinium A1 culture & - & $\mathrm{n} / \mathrm{a}$ & $\mathrm{n} / \mathrm{a}$ & $\mathrm{n} / \mathrm{a}$ & $\mathrm{n} / \mathrm{a}$ & $\mathrm{n} / \mathrm{a}$
\end{tabular}

Mussismilia hispida

Broodstock tissue

Larvae replicate 1

Larvae replicate 2

Larvae replicate 3

$\begin{array}{ccc}+ & \mathrm{n} / \mathrm{a} & \mathrm{n} / \mathrm{a} \\ \mathrm{n} / \mathrm{a} & - & - \\ \mathrm{n} / \mathrm{a} & - & - \\ \mathrm{n} / \mathrm{a} & - & -\end{array}$

$\begin{array}{ccc}\mathrm{n} / \mathrm{a} & \mathrm{n} / \mathrm{a} & \mathrm{n} / \mathrm{a} \\ - & - & - \\ - & - & + \\ - & - & -\end{array}$

Berghia stephanieae

Broodstock tissue

Larvae replicate 1

Larvae replicate 2

Larvae replicate 3

$\begin{array}{ccc}- & \mathrm{n} / \mathrm{a} & \mathrm{n} / \mathrm{a} \\ \mathrm{n} / \mathrm{a} & - & - \\ \mathrm{n} / \mathrm{a} & - & - \\ \mathrm{n} / \mathrm{a} & - & -\end{array}$

\begin{tabular}{lcccccc} 
Tridacna crocea & & & & & \\
Broodstock tissue & + & $\mathrm{n} / \mathrm{a}$ & $\mathrm{n} / \mathrm{a}$ & $\mathrm{n} / \mathrm{a}$ & $\mathrm{n} / \mathrm{a}$ & $\mathrm{n} / \mathrm{a}$ \\
Larvae replicate 1 & $\mathrm{n} / \mathrm{a}$ & - & - & + & + & + \\
Larvae replicate 2 & $\mathrm{n} / \mathrm{a}$ & - & - & + & - & + \\
Larvae replicate 3 & $\mathrm{n} / \mathrm{a}$ & - & - & - & - & - \\
\hline$+:$ positive expression & & & & & \\
- : no expression & & & & & \\
n/a : not applicable & & &
\end{tabular}

the angiosperm Arabidopsis thaliana (see Pardo and Serrano, 1989) and the planktonic green alga Platymonas viridis (see Popova and Balnokin, 1992). While many studies have observed symbiont acquisition by metazoan larvae (Fitt et al., 1986; Schwarz et al., 1999; Weis et al., 2001; Rodriguez-Lanetty et al., 2006; Marlow and Martindale, 2007; Harii et al., 2009; Cumbo et al., 2012; Ramos and Banaszak, 2014; Wolfowicz et al., 2016), very few tested metabolite exchange or symbiosis-specific molecular signals (Kopp et al., 2016; Mies et al., 2017b). For that purpose, we decided to investigate whether larvae of several marine invertebrate coral reef taxa express $\mathrm{H}^{+}$-ATPase as a result of Symbiodinium acquisition.

While only few and nearly undetectable differences were found in comparative analyses of the transcriptomes of symbiotic and aposymbiotic coral larvae (deBoer et 
al., 2007; Voolstra et al., 2009b; Schnitzler and Weis, 2010), we did find expression of $\mathrm{H}^{+}$-ATPase in Symbiodinium acquired by the larvae of the coral Mussismilia hispida. This expression was found in only one of the triplicates, at $72 \mathrm{~h}$ PSO, however. While monitoring the expression of this gene for a longer period of time would probably give a broader view on the establishment of this mutualistic symbiosis, our results do show that Symbiodinium A1 and coral larvae are able to engage in symbiosis. These findings relate to reports that Symbiodinium A1 acquired by M. hispida larvae produce a higher amount of fatty acids and present lower bleaching rates than most of the other Symbiodinium clades (Mies et al., this thesis chapters 3 and 4).

For the experiments with the nudibranch Berghia stephanieae, a valuable product in the marine ornamental trade (Olivotto et al., 2011), the expression of $\mathrm{H}^{+}$ATPase was not detected in any of the larval samples, and, more importantly, neither in the broodstock tissue sample. In fact, host larvae were digesting the symbionts. Despite evidence that Symbiodinium mutualistically translocates photosynthetically-fixed carbon to the nudibranch Pteraeolidia ianthina (Hoegh-Guldberg and Hinde, 1986), this does not seem to be the case for B. stephanieae. There is much evidence that goes against the idea of mutualism in this species, especially from the Symbiodinium perspective: B. stephanieae are nocturnal organisms and remove the symbionts from the Aiptasia anemone, which is found in sunlit areas, and later defecates the non-motile Symbiodinium cysts after 3-6 days from acquisition (Kempf, 1991). This not only deprives Symbiodinium from light, but also renders it an easy prey in the benthos. Furthermore, it has been reported that some nudibranchs sequester Symbiodinium from their prey, but may not engage in symbiosis (Rudman, 1981; Burghardt et al., 2005). Therefore, the association between B. stephanieae and Symbiodinium does not seem to fit the requirements for a mutualistic symbiosis. Regardless, this example supports that the expression of $\mathrm{H}^{+}$-ATPase is not an endocytosis signal.

In the case of Tridacna crocea, an important commodity for both the food and aquarium trade (Mies et al., 2017a), many studies based on morphological examinations suggested that symbiosis was not established until metamorphosis (Fitt et al., 1986; Hirose et al., 2006), when symbionts migrated to post-metamorphic diverticulae called zooxanthellal tubular system (Norton et al., 1992). However, studies show that veliger larvae grow faster and have increased survival if symbionts are available (Fitt et al., 1986; Mies et al., 2012). Our results show that Symbiodinium cells in two of the three 
replicates of T. crocea larvae expressed $\mathrm{H}^{+}$-ATPase, in agreement with the findings of Mies et al. (2017b) for T. maxima. Similarly to that reported for coral larvae, Symbiodinium acquired by $T$. crocea veliger also seem to produce more fatty acids and to be more resistant to bleaching (Mies et al., this thesis chapters 3 and 4). However, the expression of $\mathrm{H}^{+}$-ATPase was intermittent for one of the replicates (Table 2). While there is very little information available in the literature to explain why this would happen, we argue it may be related to the intense changes in circadian rhythm in Symbiodinium and other dinoflagellates (Rees et al., 1993; Yacobovitch et al., 2004; Pizay et al., 2009). Nonetheless, this event reinforces that the modulation of the expression $\mathrm{H}^{+}$-ATPase requires further investigation.

It is important to note that the host organisms selected for this experiment, and particularly their larval ecology, are very different (Table 1). Scleractinian coral larvae are known lecithotrophs and go through metamorphosis without any exogenous feeding (Morse et al., 1996), while giant clam veligers are planktotrophs and must feed before attaining the juvenile stage (Fitt et al., 1984; 1986; Mies et al., 2012). Based on $\mathrm{H}^{+}-$ ATPase expression, our findings argue that giant clam larvae establish symbiosis with Symbiodinium earlier than coral larvae, which could point to their higher need of exogenous nutrition. While the nudibranchs also produce lecithotrophic larvae, they are facultative planktotrophs and the Symbiodinium seems to be more of a prey item than a symbiont, as $\mathrm{H}^{+}$-ATPase was never expressed and Symbiodinium cells were digested.

While our experiments may contribute to the knowledge on the state of the symbiotic relationship between Symbiodinium and coral reef larvae by mean of $\mathrm{H}^{+}$ATPase expression, there is still an overwhelming lack of marker genes for Symbiodinium. This hinders functional genomics studies (Leggat et al., 2011). Investigating comparative differential gene expression in the free-living and coccoid stages (symbiotic) is crucial for further understanding the relationships between coral reef organisms and their symbionts. As an example, the expression of $\mathrm{H}^{+}$-ATPase may be tied to the non-motile coccoid life stage of Symbiodinium. Interestingly, the shift from free-living to coccoid stage has been shown to be chemically stimulated by lectin produced by the coral host (Kita et al., 2015). Regardless, our results support the application of $\mathrm{H}^{+}$-ATPase gene expression as a molecular symbiosis-specific marker for Symbodinium-invertebrate associations. This gene may be used for distinguishing between symbiotic and non-symbiotic associations (e.g., the case of the nudibranch $B$. 
stephanieae). Our findings may also provide insights for coral reef restoration and aquaculture protocols (Pomeroy et al., 2006; Guest et al., 2010), as early symbiont acquisition and mutualism establishment may improve survival and metamorphic competence.

\section{Acknowledgements}

We would like to express our most sincere thanks to Gustavo Duarte and the whole Coral Vivo Institute staff, Acqua Distribuidora for acquiring the giant clam broodstock for us, Diego Castillo for his technical assistance and Arthur Tenório for helping us run the cultures. This work was supported by Projeto Coral Vivo and sponsored by Petrobrás (Programa Petrobrás Socioambiental) and Arraial d'Ajuda Eco Parque. PYGS acknowledges grants 302526/2012-9 and 2010/20350-8 from CNPq and FAPESP.

\section{Author contributions}

M.M. designed the experiment, M.M. performed the experiment, C.R.V., C.B.C., D.O.P. and E.N.C. contributed with infrastructure/material/technical support, M.M. analyzed the data and M.M., P.Y.G.S., C.R.V. and M.A.V.S. wrote the manuscript. 


\title{
CHAPTER THREE
}

\section{Production of three symbiosis-related fatty acids by Symbiodinium clades A-F associated with coral reef larvae}

\author{
Mies, M. ${ }^{1 *}$; Chaves-Filho, A. B. ${ }^{2}$; Miyamoto, S. ${ }^{2}$; Güth, A. Z. ${ }^{1}$; Tenório, A. A. ${ }^{1}$; Castro, \\ C. B. ${ }^{3,4}$; Pires, D. O., ${ }^{3,4}$; Calderón, E. N. ${ }^{4,5}$ \& Sumida, P. Y. G. ${ }^{1}$
}

${ }^{1}$ Oceanographic Institute, University of São Paulo. Praça do Oceanográfico, 191 - 05508-120 São Paulo, SP - Brazil.

${ }^{2}$ Chemistry Institute, University of São Paulo. Av Prof. Lineu Prestes, 748 - 05508-000 São Paulo, SP - Brazil.

${ }^{3}$ Museu Nacional, Universidade Federal do Rio de Janeiro. Quinta da Boa Vista, s/n - 20940040 Rio de Janeiro, RJ - Brazil.

${ }_{4}^{4}$ Instituto Coral Vivo. Rua dos Coqueiros, 87 -45807-000 Santa Cruz Cabrália, BA - Brazil.

${ }^{5}$ Núcleo em Ecologia e Desenvolvimento Socioambiental de Macaé, Universidade Federal do Rio de Janeiro. Av São José do Barreto, 764 - 27965-045 Macaé, RJ - Brazil.

* Corresponding author: miguel.mies@usp.br

\begin{abstract}
Symbiodinium are phototrophic dinoflagellates engaged in a mutualistic symbiosis with multiple coral reef taxa. They are divided in nine different clades (A-I), which typically associate with different hosts. However, it is still unknown if Symbiodinium clades present differences in metabolism, especially when associated with metazoan larvae. We tested if three $\omega 3$ fatty acids (SDA, DPA and DHA) that are typically translocated from Symbiodinium to its host are produced in Symbiodinium clades A-F associated with Mussismilia hispida (scleractinian coral), Berghia stephanieae (nudibranch) and Tridacna crocea (giant clam) larvae. For that purpose, we acquired and spawned broodstock for each host, cultured their larvae and offered Symbiodinium clades A-F. Samples were taken during a 72-h window after the offer of Symbiodinium and fatty acids were extracted and analyzed by gas chromatography. The concentrations for SDA and DPA for all host larvae-dinoflagellate associations were low and variable, without any trends. However, M. hispida planula larvae associated with Symbiodinium A and C had a statistically significant higher amount of DHA. The veliger larvae of $B$.
\end{abstract}


stephanieae digested the Symbiodinium and the amount of DHA remained constant throughout the experiment. The veliger larvae of $T$. crocea associated with Symbiodinium A and C also presented a higher amount of DHA, although not statistically different from the other clades. These results show that Symbiodinium clades A and C, homologous to M. hispida and T. crocea, may contribute with a small amount of DHA to the symbiotic associations within these host larvae and form a stronger mutualism than the other clades.

Keywords: zooxanthellae, Scleractinia, Tridacna, gas chromatography, lipids, larval ecology

\section{Introduction}

Symbiodinium are photosynthetic dinoflagellates responsible for the majority of the primary production in coral reefs (Muscatine and Porter, 1977; Muscatine et al., 1981). These organisms are found in either a free-living or a non-motile coccoid stage (Freudenthal, 1962; Schoenberg and Trench, 1980), with the latter found in higher abundances and engaged in a mutualistic symbiosis with several metazoan and protist phyla (Stat et al., 2006; Venn et al., 2008). Based on molecular phylogenies inferred on ribosomal genes (Rowan and Powers, 1991; LaJeunesse, 2001), Symbiodinium dinoflagellates are divided in nine clades, A-I (Pochon and Gates, 2010). The ancestral clade A originated in the Eocene about 50 million years ago, with most extant strains diversifying about 15 million years go in the Miocene (Tchernov et al., 2004; Pochon et al., 2006).

Each Symbiodinium clade tends to associate with specific hosts (Baker, 2003; Coffroth and Santos, 2005) and usually the host taxon associates with a single symbiont strain (LaJeunesse, 2002; Goulet, 2006). For instance, clades A-D are usually found in cnidarians and mollusks, while clades F-I are typically found in foraminiferans (Stat $e t$ al., 2006; Pochon and Gates, 2010). However, Symbiodinium can be diverse within the host, as multiple clades have been found in a single host individual on numerous occasions (Rowan and Powers, 1991; Rowan and Knowlton, 1995; Carlos et al., 2000; Baker, 2003; Loh et al., 2006; Picciani et al., 2016). Host-symbiont recognition mechanisms take place during initial infection and the host organism may exert some control on which Symbiodinium strains it will harbor (Belda-Baillie et al., 1999; Weis et al., 2001; Little et al., 2004; Coffroth and Santos, 2005), and also on its density inside the tissues (Gordon and Leggat, 2010). Symbiodinium clades can also be specialized in 
certain niches, as some strains are more adapted to lower light intensity found in higher depths (Cooper et al., 2011) and others more tolerant to high temperatures (van Oppen et al., 2005; Ladner et al., 2012).

The symbiosis between Symbiodinium and its host is mutualistic. In exchange for protection, $\mathrm{CO}_{2}$ and substrate for cellular synthesis, the symbiont supplies the host with metabolites such as glycerol, glucose and fatty acids, among other organic compounds (Trench, 1979; Muscatine, 1990; Grant et al., 1997; Allemand et al., 1998).

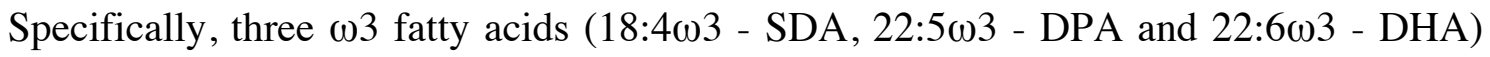
are considered dinoflagellate markers and are translocated from Symbiodinium to host (Graeve et al., 1994; Zhukova and Aizdaicher, 1995; Papina et al., 2003). However, it is unknown if the Symbiodinium clades may present differences in their metabolic contributions to the host. Furthermore, while translocation of photosynthates to the adult host has been well described, it remains largely untested for hosts undergoing larval development.

In light of such issues, this experiment intends to answer the question whether different Symbiodinium clades present different production rates of symbiosis-related $\omega 3$ fatty acids when associated with coral reef larvae. For that purpose, we cultured the larvae of a scleractinian coral, a nudibranch and a giant clam and offered Symbiodionium clades A-F. Then we monitored the increase and production of the three symbiosis-related $\omega 3$ fatty acids SDA, DPA and DHA. Studying the metabolic relationship between coral reef larvae and Symbiodinium is of paramount importance, as it may provide insights for the recruitment in coral reefs and also perhaps aid in programs related to coral reef restoration and the mitigation of climate change impacts.

\section{Materials and methods}

The experimental design had the purpose of detecting increments in the concentration of

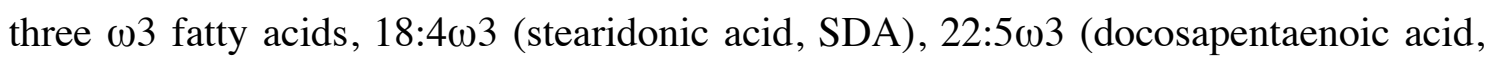
DPA) and 22:603 (docosahexaenoic acid, DHA), in the association between Symbiodinium clades A-F and the larvae of Mussismilia hispida (hermatypic coral), Berghia stephanieae (nudibranch) and Tridacna crocea (giant clam). For that, we cultured the larvae, offered cultured Symbiodinium, collected samples and performed fatty acid extraction and gas chromatography analysis. 
Symbiodinium culture

The Symbiodinium (ITS2 types A1, B1, C1, D1, E1 and F1) were cultured in f/2 medium (Guillard and Ryther, 1962), at $23^{\circ} \mathrm{C}$ and with a photon flux of $100 \mu \mathrm{E} \mathrm{m}^{-2} \mathrm{~s}^{-1}$ in a photoperiod of $12 \mathrm{~L}: 12 \mathrm{D}$. The antibiotics streptomycin $\left(0.5 \mathrm{~g} \mathrm{~L}^{-1}\right)$ and penicillin were used $\left(1.0 \mathrm{~g} \mathrm{~L}^{-1}\right)$.

\section{Broodstock maintenance and spawning}

All hosts selected for this experiment are simultaneous hermaphrodites and acquire symbionts horizontally (Carroll and Kempf, 1990; Neves and Pires, 2002; Mies et al., 2012). Broodstock for all hosts was maintained in conditions that simulated tropical reef waters, with temperature at $27^{\circ} \mathrm{C}$, specific gravity at $1,024 \mathrm{~kg} \mathrm{~m}^{-3}$ and nutrients at undetectable levels. Mussismilia hispida colonies $(\mathrm{n}=30,17.5 \pm 3.5 \mathrm{~cm}$ in approximate diameter) were collected at the Recife de Fora $\left(16^{\circ} 25^{\prime} \mathrm{S}, 38^{\circ} 59^{\prime} \mathrm{W}\right)$ in northeastern Brazil and kept in semi-closed tanks. Natural spawns occurred in the evenings of September 2015 and gamete bundles were collected immediately after release and later fertilized in 60-L round tanks. Strong aeration was provided in order to prevent larvae from becoming trapped in the surface tension. Water changes of $90 \%$ were performed daily for four days until planulae were capable of acquiring symbionts. Broodstock of the nudibranch $B$. stephanieae was produced in the lab from originally 12 individuals according to the recommendations in Carroll and Kempf (1990) and Mies et al. (in preparation). A total of 95 broodstock individuals $(1.5 \pm 0.2 \mathrm{~cm}$ in length) were produced and kept in a recirculating aquaria system of $250 \mathrm{~L}$. A mesh of $250 \mu \mathrm{m}$ installed on the drainpipe prevented the nudibranchs from escaping the tank. The broodstock was heavily fed with 100 individuals of the glass anemone Aiptasia sp. (B. stephanieae are stenophagous nudibranchs that acquire both nutrition and symbionts exclusively from Aiptasia spp. and present a short larval development of about $48 \mathrm{~h}-$ see Carroll and Kempf, 1990 and Leal et al., 2012). Spawns were collected in the next morning and kept for 10 days under strong aeration in order to stimulate the release of veliger larvae (Carroll and Kempf, 1990). Ten broodstock $T$. crocea clams $(7.6 \pm 0.9 \mathrm{~cm}$ in shell length) were kept in a recirculated system of $350 \mathrm{~L}$ and induced to spawn by an intragonadal injection of $1.0 \mathrm{~mL}$ of serotonin (5-hydroxytryptamine, $1.0 \mathrm{~g} \mathrm{~L}^{-1}$ ) 
according to the procedures in Braley (1985) and Mies et al. (2013). Spawned gametes were fertilized in $60 \mathrm{~L}$ round tubs according to the procedures in Heslinga et al. (1990). Daily water changes of 50-60\% were performed during the embryonic and larval development, until all larvae had reached the veliger larval stage, at $72 \mathrm{~h}$ postfertilization.

Larval cultures, Symbiodinium offering and sampling

The larvae produced for each host were stocked in 1.2-L plankton kreisels with filtered seawater. Four days post-fertilization (PF) Mussismilia hispida planulae were stocked at 0.8 larva $\mathrm{mL}^{-1}$, ten days $\mathrm{PF}$ B. stephanieae veligers at $1.0 \mathrm{~mL}^{-1}$ and three days PF $T$. crocea veligers at $2.0 \mathrm{~mL}^{-1}$. The kreisels were placed in a water bath at $27^{\circ} \mathrm{C}$. Twentyone plankton kreisels were used for each host larvae; three replicated kreisels for each one of the six Symbiodinium clades (A-F) and one control group to which no symbionts were offered. The Symbiodinium were then offered at a final concentration of $10^{3}$ cells $\mathrm{mL}^{-1}$. At $11 \mathrm{~h}$ post-symbiont offering (PSO), Symbiodinium acquisition was recorded and a water change of $100 \%$ was performed in all kreisels in order to prevent symbiont reacquisition. Samples of 25, 25 and 200 larvae were taken for M. hispida, $B$. stephanieae and T. crocea, respectively, at 0, 12, 24, 48 and $72 \mathrm{~h}$ PSO. Together with each sample, three larvae were collected, measured (length) and squashed under the microscope and the Symbiodinium mitotic index (Wilkerson, 1983) was recorded. Survival was also monitored during sampling.

Fatty acids extraction and analysis

Collected samples were macerated with glass beads, a mortar and a pestle in $120 \mu \mathrm{L}$ of water for 2 minutes, before being vortexed for 3 minutes and centrifuged for collection. Extraction was performed in similar fashion to Masood et al. (2005). Briefly, $90 \mu \mathrm{L}$ of the sample was incubated with $50 \mu \mathrm{L}$ of margaric acid $\left(\mathrm{C} 17: 0,1.0 \mathrm{mg} \mathrm{mL}^{-1}\right), 1.85 \mathrm{~mL}$ of methanol and $100 \mu \mathrm{L}$ of acetyl chloride for one hour at $100^{\circ} \mathrm{C}$. Hexane was added and the organic layer transferred to a fresh tube. The solution was evaporated under $\mathrm{N}_{2}$ until dry and the residue dissolved in $100 \mu \mathrm{L}$ of hexane. The individual fatty acid methyl esters (FAMEs) were analyzed by a Trace 1310 gas chromatograph (Thermo 
Scientific) equipped with a flame ionization detector. FAMEs were separated with a DB-FFAP column of $15 \mathrm{~m}$ x $0.1 \mathrm{~mm}$ ID x $0.1 \mu \mathrm{m}$ film thickness (J \& W Scientific, Agilent Technologies). The temperature program started at $150^{\circ} \mathrm{C}$ with a 15 -second hold, before increasing $35^{\circ} \mathrm{C}$ per minute to $200^{\circ} \mathrm{C}, 8^{\circ} \mathrm{C}$ per minute to $225^{\circ} \mathrm{C}$ with a $3.2-$ minute hold, $80^{\circ} \mathrm{C}$ per minute to $245^{\circ} \mathrm{C}$ and finishing with a 4.75 -minute isothermal period. A mixture of hydrogen and nitrogen was used as carrier gas. The FAMEs were identified by direct comparison of their retention times with the PUFA $\mathrm{N}^{\mathrm{o}} 1$ Marine Source (Sigma-Aldrich) standard mix. Each individual peak was integrated and normalized by the internal standard (C17:0). The amount of FAMEs detected was normalized by the number of larvae in the samples.

\section{Statistical analysis}

Statistical analyses were performed independently for each host larvae. In order to verify if time and Symbiodinium clade influence the amount of SDA, DPA and DHA, a two-way analysis of variance (ANOVA) was performed. To verify which treatments (clades) were statistically different at the end of the experiment, a one-way ANOVA was performed on the $72 \mathrm{~h}$ samples, with a post-hoc Tukey's HSD test. Finally, a oneway ANOVA was performed on the $72 \mathrm{~h}$ samples for survival and growth to test if there were any significant differences between larvae associated with Symbiodinium clades A-F.

\section{Results}

Symbiont acquisition was higher than $99 \%$ for all Symbiodinium clades and all host larvae. While the amount acquired for Berghia stephanieae and Tridacna crocea larvae was similar for all clades, Mussismilia hispida acquired Symbiodinium A1 cells nearly twice as much as the other clades (Table 1). While symbionts remained intact in $M$. hispida and T. crocea larvae throughout the experiment, B. stephanieae larvae appeared to digest most of the symbiont cells acquired for all clades. The mitotic index (Table 1) shows that approximately $10-15 \%$ of the Symbiodinium cells (for all clades) acquired by M. hispida and T. crocea were undergoing division while only $6 \%$ for B. stephanieae larvae. 
Table 1 Acquisition of Symbiodinium clades A-F by Mussismilia hispida (scleractinian coral), Berghia stephanieae (nudibranch) and Tridacna crocea (giant clam) larvae after 11 hours of exposure. The average mitotic index of acquired Symbiodinium during the 72-h experiment is also presented.

\begin{tabular}{lcccccc}
\hline & \multicolumn{2}{c}{ Mussismilia hispida } & \multicolumn{2}{c}{ Berghia stephanieae } & \multicolumn{2}{c}{ Tridacna crocea } \\
Clade & $\begin{array}{c}\text { Symbiodinium } \\
\text { cells acquired }\end{array}$ & $\begin{array}{c}\text { Symbiodinium } \\
\text { mitotic index }\end{array}$ & $\begin{array}{c}\text { Symbiodinium } \\
\text { cells acquired }\end{array}$ & $\begin{array}{c}\text { Symbiodinium } \\
\text { mitotic index }\end{array}$ & $\begin{array}{c}\text { Symbiodinium } \\
\text { cells acquired }\end{array}$ & $\begin{array}{c}\text { Symbiodinium } \\
\text { mitotic index }\end{array}$ \\
\hline Control & $0.0 \pm 0.0$ & $\mathrm{n} / \mathrm{a}$ & $0.0 \pm 0.0$ & $\mathrm{n} / \mathrm{a}$ & $0.0 \pm 0.0$ & $\mathrm{n} / \mathrm{a}$ \\
$\mathrm{A}$ & $194.5 \pm 31.6$ & $0.14 \pm 0.04$ & $19.2 \pm 5.0$ & $0.05 \pm 0.03$ & $36.6 \pm 6.5$ & $0.09 \pm 0.03$ \\
$\mathrm{~B}$ & $123.2 \pm 22.9$ & $0.12 \pm 0.02$ & $18.5 \pm 5.4$ & $0.04 \pm 0.04$ & $33.5 \pm 10.7$ & $0.14 \pm 0.07$ \\
$\mathrm{C}$ & $125.2 \pm 18.6$ & $0.14 \pm 0.07$ & $19.5 \pm 3.1$ & $0.10 \pm 0.03$ & $38.1 \pm 3.2$ & $0.14 \pm 0.06$ \\
$\mathrm{D}$ & $119.0 \pm 30.2$ & $0.19 \pm 0.05$ & $16.5 \pm 1.0$ & $0.08 \pm 0.03$ & $31.7 \pm 9.0$ & $0.11 \pm 0.04$ \\
$\mathrm{E}$ & $123.5 \pm 21.9$ & $0.12 \pm 0.05$ & $18.2 \pm 2.9$ & $0.06 \pm 0.03$ & $32.0 \pm 8.4$ & $0.06 \pm 0.05$ \\
$\mathrm{~F}$ & $102.2 \pm 27.9$ & $0.13 \pm 0.05$ & $13.5 \pm 2.3$ & $0.05 \pm 0.02$ & $31.1 \pm 7.7$ & $0.14 \pm 0.01$ \\
\hline $\mathrm{n} / \mathrm{a}:$ not applicable & & & & &
\end{tabular}

For all host larvae, no significant differences were found in survival at the end of the experiment between the control group (larvae without Symbiodinium) and the treatments for the six clades. The same was verified for growth. While M. hispida and $T$. crocea larvae grew steadily during the experiment, $B$. stephanieae larvae showed a remarkable increase in size at $48 \mathrm{~h}$ post-hatch and PSO (Fig. 1). This is related to the fact that veliger larvae underwent metamorphosis and juvenile nudibranchs discarded their shells and fully extended their body.

The results for SDA and DPA showed no patterns and their content was highly variable throughout the experiment, for all host larvae (Fig. 2). In the case of DPA, it was nearly undetectable for B. stephanieae and T. crocea larvae and in fact undetectable for some $T$. crocea samples. In order to detect if time and treatment could influence the SDA and DPA content, a two-way ANOVA was performed, but no significant differences were found for all host larvae. In the case of DHA, it is possible to observe a slight increase in its content for all host larvae associated with most clades at $12 \mathrm{~h}$ PSO (Fig. 3). Another increase takes place at $48 \mathrm{~h}$ PSO for M. hispida and T. crocea larvae associated with Symbiodinium A and C. Time does influence the amount of DHA for $M$. hispida larvae (two-way ANOVA, F = 7.0, $\mathrm{df}=4, p<0.001$ ), but there is no influence of Symbiodinium clade. However, the interaction between time and clade does influence $(\mathrm{F}=3.0, \mathrm{df}=24, p<0.001)$. Furthermore, there are significant differences 

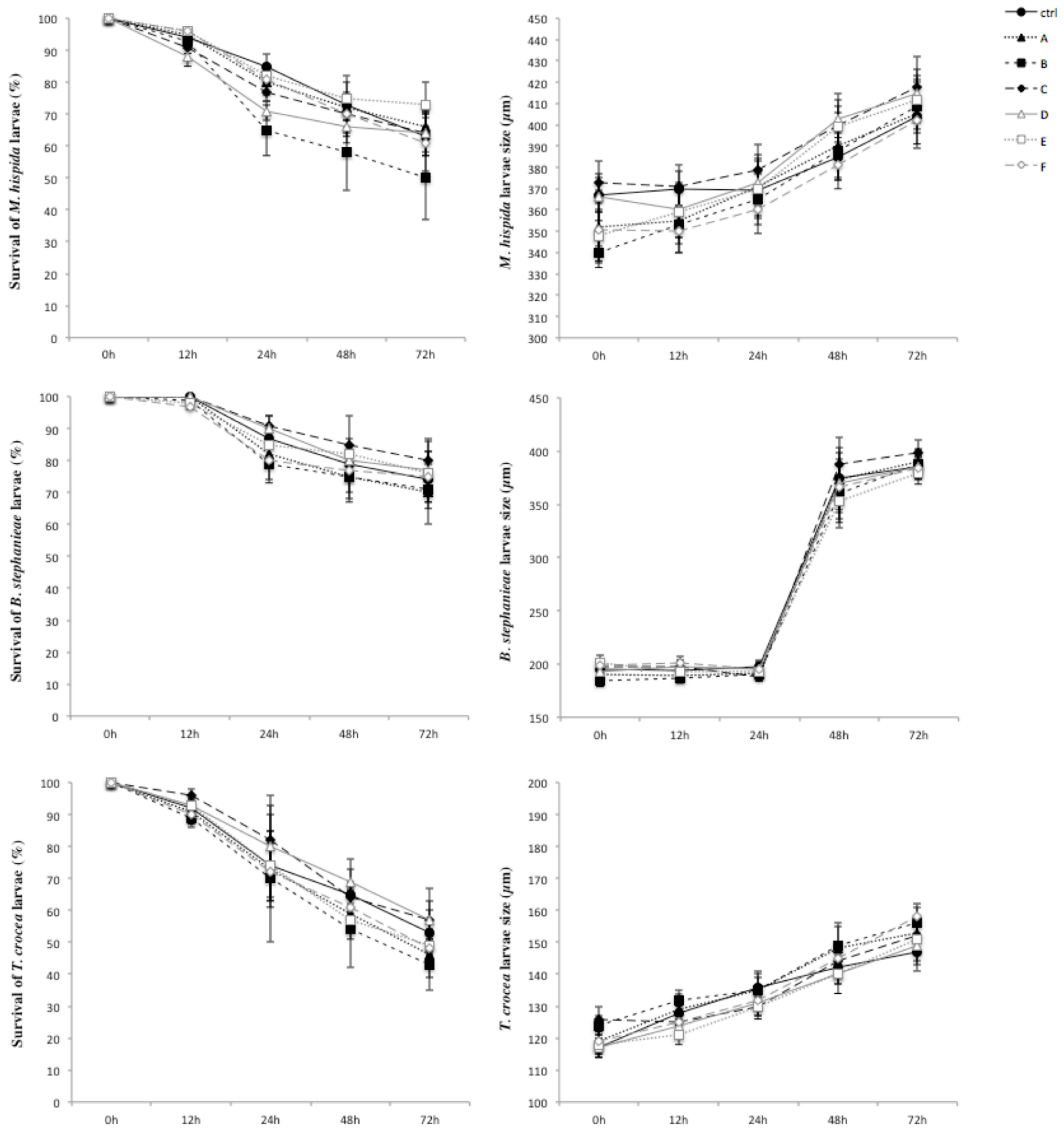

Fig. 1 Survival and growth (at $27^{\circ} \mathrm{C}$ ) of Mussismilia hispida (scleractinian coral), Berghia stephanieae (nudibranch) and Tridacna crocea (giant clam) larvae during a 72-h window after acquiring Symbiodinium clades A-F.

in the amount of DHA in the $72 \mathrm{~h}$ samples for M. hispida larvae associated with Symbiodinium clades A and C when compared to the control and other clades (one-way ANOVA, $\mathrm{F}=10.4$, df $=6, p<0.001)$. The amount of DHA for $M$. hispida larvae associated with Symbiodinium clades A and C at 72 h PSO was $20 \%$ and $22 \%$, 

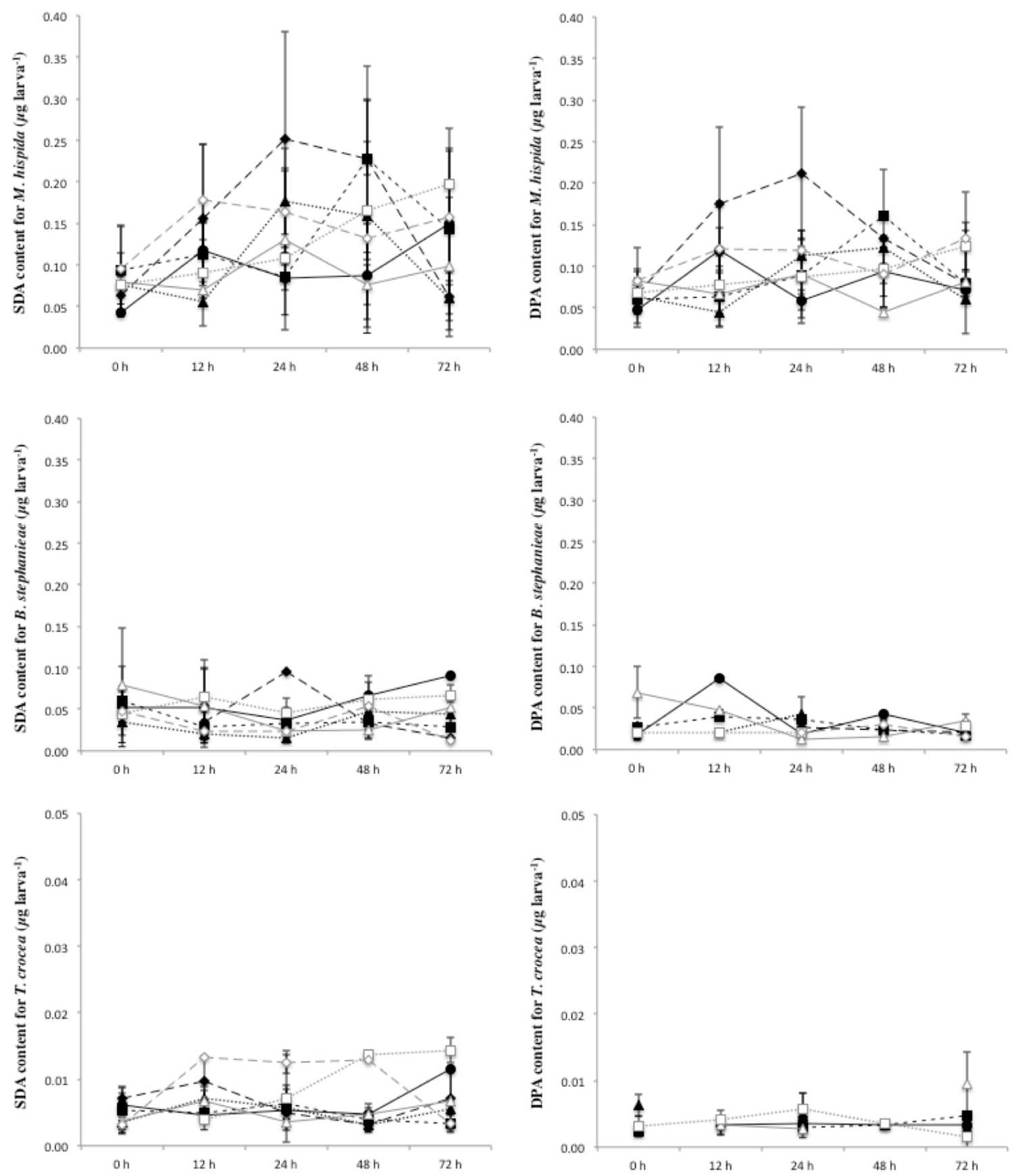

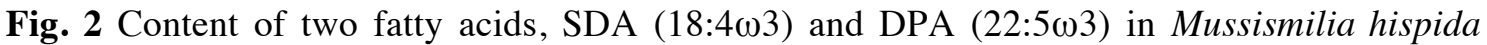
(scleractinian coral), Berghia stephanieae (nudibranch) and Tridacna crocea (giant clam) larvae during a 72-h window after acquisition of Symbiodinium clades A-F. Data missing for DPA in $T$. crocea larvae is due to undetectably low concentrations.

respectively, higher than at $12 \mathrm{~h}$ PSO. In the case of $B$. stephanieae, DHA amount was approximately constant throughout the experiment and neither time, Symbiodinium clade nor their interaction presented any significant differences. For T. crocea larvae, time did influence the amount of DHA (two-way ANOVA, $\mathrm{F}=6.3$, df $=4, p<0.001$ ), but no differences were found for Symbiodinium clade or its interaction with time. 
However, T. crocea larvae associated with Symbiodinium clades A and C showed higher amounts of DHA than larvae associated with other clades and the control group despite not showing statistically significant differences (Fig. 3). The amount of DHA for T. crocea larvae associated with Symbiodinium clades A and C at $72 \mathrm{~h}$ PSO was $28 \%$ and $27 \%$, respectively, higher than at $12 \mathrm{~h}$ PSO.

\section{Discussion}

Fatty acids are important tools for investigations in trophic ecology. When a given organism consumes certain fatty acids, these are often routed to energy reserves or tissues with little or no modification, becoming a record of dietary habit (Ruess et al., 2005; Budge et al., 2006). Highly unsaturated fatty acids are particularly useful as they are produced by phytoplankton species and cannot be synthesized de novo by animals (Volkman et al., 1989; Dalsgaard et al., 2003). While, on rare occasions, some animals are able to elongate and desaturate fatty acids and convert them into highly unsaturated compounds, this is performed at low and insignificant amounts (Nevejan et al., 2003). This is mostly related to the fact that, contrary to photoautotrophs, animals lack enzymes required to produce double bonds at certain positions in the carbon chain (Bachok et al., 2006). Highly unsaturated fatty acids must therefore be acquired from dietary items and thus are important trophic markers in marine ecology, as extensively reviewed in Dalsgaard et al. (2003), Bergé and Barnathan (2005) and Budge et al. (2006).

In light of such context, we tested if the $\omega 3$ fatty acids SDA, DPA and DHA are produced in different rates by Symbiodinium clades A-F associated with coral, nudibranch and giant clam larvae. These fatty acids are symbiosis-related as they are translocated from Symbiodinium to its host (Papina et al., 2003). Considering that these fatty acids are found in both Symbiodinium (Mansour et al., 1999; Zhukova and Titlyanov, 2003; Mortillaro et al., 2009) and coral reef larvae (Arai et al., 1993; Figueiredo et al., 2012; Leal et al., 2012), although the latter are incapable of producing them, our intention was to find increments in the amounts of these fatty acids in host larvae. As they are only produced by the symbiont and no other organisms other than the larvae were present in the filtered seawater used for the larval cultures, any increments would have to result from the production by Symbiodinium. 

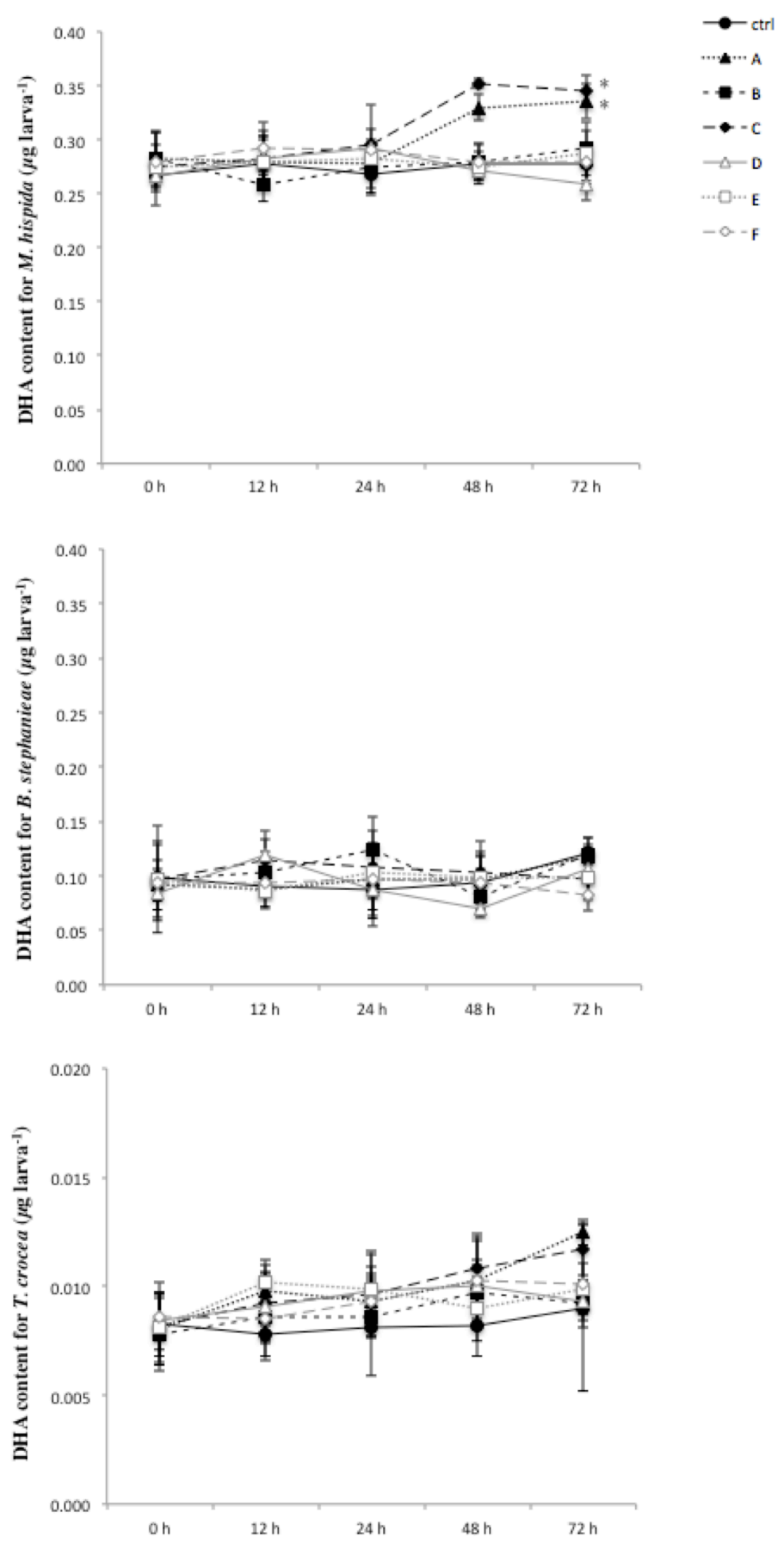

Fig. 3 DHA (22:6w3) content in Mussismilia hispida (scleractinian coral), Berghia stephanieae (nudibranch) and Tridacna crocea (giant clam) larvae during a 72-h window after acquisition of Symbiodinium clades A-F. Asterisks denote significantly different (Tukey's HSD, $p<0.05$ ) DHA content at the end of the experiment. 
SDA and DPA are considered dinoflagellate-specific markers, despite occurring in other marine phytoplankton species at lower concentrations (Graeve et al., 1994; Zhukova and Aizdaicher, 1995). The amount of both fatty acids found in the larvae of Mussismilia hispida, Berghia stephanieae and Tridacna crocea associated with Symbiodinium clades A-F was very low (Fig. 1). In the case of DPA for T. crocea it was below the detection limit of the gas chromatograph for some samples. Higher amounts were found in the M. hispida samples, possibly because the larvae are larger and also acquired a higher number of symbionts (Table 1). Nonetheless, the concentrations for both SDA and DPA were highly variable for all host larvae and all Symbiodinium clades and no practical conclusions can be reached for this experiment. However, this does not exclude the possibility that these compounds may have a role in metazoan larvaeSymbiodinium associations.

In the case of DHA, however, the data produced show interesting trends. For all host larvae, there was an increase in DHA content in the $12 \mathrm{~h}$ sample (Fig. 3). This is most likely related to the acquisition of symbionts that took place in between the 0 and $12 \mathrm{~h}$ sampling periods. However, a higher increase was found at 48 and $72 \mathrm{~h}$ PSO for M. hispida and T. crocea larvae associated with Symbiodinium clades A and C, statistically significant in the case of M. hispida. While our experimental design cannot account for translocation of photosynthates from these Symbiodinium strains to host larvae, it is highly possible as Symbiodinium are known to translocate more than $90 \%$ of its carbon production to the host (Muscatine and Porter, 1977; Muscatine, 1990). Furthermore, the increase in DHA amount for $M$. hispida and $T$. crocea larvae associated with clades $\mathrm{A}$ and $\mathrm{C}$ is higher than $20 \%$, which is more than the $10-15 \%$ reproductive stage cells recorded during their larval development (Table 1). This suggests that more DHA was being produced than the necessary for reproduction. Our findings are in accordance with reports that M. hispida and T. crocea larvae associated with Symbiodinium clade A1 engage in symbiosis-specific gene expression and have lower bleaching rates than larvae associated with other clades (Mies et al., this thesis chapters 2 and 4). While DHA seems to be a relevant trophic marker and may be translocated from symbiont to host larvae, we found no significant differences in survival and growth for larvae associated with Symbiodinium clades A and C. This is in agreement with reports that Symbiodinium does not contribute significantly to the nutrition of larvae of the scleractinian coral Pocillopora damicornis (Kopp et al., 2016). 
Therefore, it is possible that this contribution becomes significant only at later stages in the development. In the case of B. stephanieae, however, there is little indication of symbiotic exchange during the larval development as both veliger larvae and juvenile individuals sampled in this experiment were digesting the Symbiodinium cells.

The reason why Symbiodinium clades A and C presented conspicuous data when associated with $M$. hispida and $T$. crocea larvae in this experiment may be related to symbiont homology. Apart from Symbiodinium A and C being the most abundant and well-adapted clades (Pochon et al., 2006; Stat et al., 2006), both host species naturally harbor these two strains (DeBoer et al., 2012; Picciani et al., 2016). It has been widely reported that hosts have recognition mechanisms for selecting homologous symbiont clades (Weis et al., 2001; Fransolet et al., 2012), and these would establish a more robust symbiosis, with positive impacts on host fitness (Trench et al., 1981; Weis et al., 2001(Belda-Baillie et al., 2002; Rodriguez-Lanetty et al., 2003).

The findings in this study suggest that early acquisition of homologous symbionts may contribute to a higher content of $\omega 3$ fatty acids that are important for coral reef larvae nutrition. Apart from being relevant to the current understanding on animal-dinoflagellate symbioses, our results are particularly important for coral reef conservation and restocking programs that rely on aquaculture. Furthermore, our findings may be useful for recruitment prediction models, which have become increasingly important in the current scenario of climate change.

\section{Acknowledgements}

We would like to thank Mary Alice Coffroth for supplying the Symbiodinium cultures, Flávia SaldanhaCorrêa for maintaining them, the entire Coral Vivo Institute staff, Henrique Alves for designing the plankton kreisels, Priscilla Derogis and Linda Waters. This work was supported by Projeto Coral Vivo and sponsored by Petrobrás (Programa Petrobrás Socioambiental) and Arraial d'Ajuda Eco Parque. PYGS acknowledges grants 302526/2012-9 and 2010/20350-8 from CNPq and FAPESP.

\section{Author contributions}

M.M. designed the experiment, M.M., A.B.C.F. and A.A.T. performed the experiment, A.B.C.F., S.M., C.B.C., D.O.P. and E.N.C. contributed with infrastructure/material/technical support, M.M., A.B.C.F., S.M. and A.Z.G. analyzed the data and M.M. and P.Y.G.S. wrote the manuscript. 


\title{
CHAPTER FOUR
}

\section{Bleaching in coral reef larvae associated with Symbiodinium clades A-F}

\author{
Mies, M. ${ }^{1 *}$; Güth, A. Z. ; Castro, C. B. ${ }^{2,3}$; Pires, D. O. ${ }^{2,3}$; Calderón, E. N. ${ }^{3,4}$; Pompeu, M. ${ }^{1}$ \\ \& Sumida, P. Y. G. ${ }^{1}$
}

${ }^{1}$ Oceanographic Institute, University of São Paulo. Praça do Oceanográfico, 191 - 05508-120

São Paulo, SP - Brazil.

${ }^{2}$ Museu Nacional, Universidade Federal do Rio de Janeiro. Quinta da Boa Vista, s/n - 20940-

040 Rio de Janeiro, RJ - Brazil.

${ }^{3}$ Instituto Coral Vivo. Rua dos Coqueiros, 87 -45807-000 Santa Cruz Cabrália, BA - Brazil.

${ }^{4}$ Núcleo em Ecologia e Desenvolvimento Socioambiental de Macaé, Universidade Federal do

Rio de Janeiro. Av São José do Barreto, 764 - 27965-045 Macaé, RJ - Brazil.

\footnotetext{
* Corresponding author: miguel.mies@usp.br
}

\begin{abstract}
Coral reefs are diverse ecosystems because of the presence of dinoflagellates (genus Symbiodinium) that are found in symbiotic association with multiple phyla and perform the majority of primary production. However, coral reefs are currently threatened by climate change and, especially, the bleaching phenomenon, which is caused by increase in seawater temperature. While bleaching has been well documented for host organisms, it is still poorly understood in larval stages. We offered Symbiodinium clades A-F to the larvae of Mussimilia hispida (scleractinian coral), Berghia stephanieae (nudibranch) and Tridacna crocea (giant clam) and gradually manipulated temperature to 26, 29 and $32^{\circ} \mathrm{C}$. Samples were taken at $0,12,24,48$ and $72 \mathrm{~h}$ post-temperature increase, chlorophyll- $a$ (chl-a) was extracted and its content measured in a fluorometer. Results show that Symbiodinium clade, temperature and time all influence in the chl-a content. Mussismilia hispida larvae displayed a bleaching threshold at $29^{\circ} \mathrm{C}$, and larvae containing clades $\mathrm{A}-\mathrm{F}$ all bleached at $32^{\circ} \mathrm{C}$, but with larvae associated with clade $\mathrm{A}$ showing a significantly lower bleaching. Berghia stephanieae digested the symbionts
\end{abstract}


and while chl-a content decreased over time in equal fashion for all clades, it is not possible to determine if it is related to bleaching. Tridacna crocea larvae at $29^{\circ} \mathrm{C}$ bleached for all clades, except for A. At $32^{\circ} \mathrm{C}$, all clades bleached but clade A bleached significantly less. These findings show that clade A seems to be more thermo-tolerant in coral reef larvae, but this may be related to the fact that it is homologous to both $M$. hispida and T. crocea. Therefore, symbiont type may have an important role in coral reef larval development and present relevant implications for recruitment.

Keywords: zooxanthellae, Tridacna, Scleractinia, larval ecology, chlorophyll, temperature

\section{Introduction}

Coral reefs are the most diverse marine ecosystems, and despite occupying only $0.2 \%$ of the ocean area, they harbor millions of eukaryotic and prokaryotic species (Connell, 1978; Sheppard et al., 2009; Knowlton et al., 2010 and references therein). Besides presenting such high biodiversity, coral reefs are economically valuable and worth hundreds of billions (USD) yearly (Moberg and Folke, 1999). Apart from supplying animal protein to local communities, coral reefs are an important resource for commercial fisheries, tourism and recreation, pharmaceuticals and the aquarium trade (Brander et al., 2007; Newton et al., 2007; Olivotto et al., 2011; Lima et al., 2013). The existence of coral reefs is much dependent on the symbiosis between reef-building corals and photosynthetic dinoflagellates of the genus Symbiodinium (Cesar, 2000; Hughes et al., 2003; Pandolfi et al., 2003). Symbiodinium dinoflagellates are found in an endosymbiotic association with several metazoan and protist phyla, including Cnidaria, Mollusca, Porifera, Acoelomorpha, Foraminifera and Ciliophora (Stat et al.,

2006; Barneah et al., 2007; Venn et al., 2008). This symbiosis is important because, apart from both parties exchanging metabolites (Muscatine, 1990; Grant et al., 1997; Allemand et al., 1998; Leggat et al., 2003), Symbiodinium facilitates calcium deposition in their reef-building hosts (Muscatine, 1990; Furla et al., 2005; Colombo-Pallotta et al., 2010).

However, this symbiotic relationship and coral reefs in their entirety are currently threatened by climate change and anthropogenic influence. Among the main impacts are ocean acidification (Hoegh-Guldberg et al., 2007), pollution (Hughes et al., 2003) and, possibly the most damaging to date, the bleaching phenomenon (Hughes et al., 2003; 2007; Baker et al., 2008). The bleaching event is defined by the loss of 
Symbiodinium from host tissue which, associated with the loss of non-photosynthetic pigments and tissue breakdown turns the coral pale white, as a consequence of the exposure of its calcareous skeleton (Brown, 1997; Hoegh-Guldberg, 1999; Fitt et al., 2001). The main cause of bleaching is the increase in seawater temperature, which damages the symbiont photosystem II (Iglesias-Prieto et al., 1992; Fitt et al., 2001). This results in the production of reactive oxygen species, which causes cellular damage in both host and symbiont and culminates in the expulsion of the symbiont and disruption of the symbiotic relationship (Lesser, 2006; Weis, 2008; Yakovleva et al., 2009). Considering that, in most cases, the symbiotic relationship is obligatory for the host, the bleaching phenomenon often leads to host death (Glynn, 1996). This highlights the crucial importance of Symbiodinium dinoflagellates in the survival of coral reef ecosystems.

The response of Symbiodinium to fluctuations in abiotic parameters is variable among strains. Symbiodinium are divided in nine clades, A-I (Rowan and Powers, 1991; Pochon and Gates, 2010), with clade D being notoriously more thermo-tolerant than others (Chen et al., 2003; Mieog et al., 2009; Ladner et al., 2012), while clade C is known to be adapted to low irradiance (Cooper et al., 2011). Symbiodinium clades also occupy different host niches, as cnidarians and mollusks usually associate with clades A-D, sponges with clades B, D and G and foraminiferans with clades F-I (Stat et al., 2006; Pochon and Gates, 2010). In addition, more than a single clade can be found within the tissues of an individual host (Rowan and Powers, 1991; Carlos et al., 2000; Baker, 2003).

Most of the research performed on bleaching impacts has been carried out on adult hosts, with several reports produced on the bleaching intensity and rates (Ralph et al., 2005; Strychar et al., 2005; Venn et al., 2006). However, only a few bleaching experiments were performed for hosts undergoing larval development (in the brooding corals Porites astreoides and Pocillopora damicornis) and the symbiont clade in the larval tissue was not identified in any of those cases (Edmunds et al., 2005; Haryanti et al., 2015). Therefore, our study aims to answer two different questions: i) if bleaching occurs in different types of coral reef larvae and ii) if there is any Symbiodinium clade that is more resistant to bleaching when associated with larvae. For those purposes, we investigated the bleaching rates in Symbiodinium clades A-F associated with the larvae of Mussismilia hispida (scleractinian coral), Berghia stephanieae (nudibranch) and 
Tridacna crocea (giant clam). Considering that bleaching events should intensify in the coming times (Hoegh-Guldberg, 1999; Baker et al., 2008), by investigating such symbiotic relationships we aim to contribute to the understanding of animaldinoflagellate symbioses during larval stages, which may be important for recruitment prediction models and contribute to conservation programs and assessments of climate change scenarios.

\section{Materials and methods}

The experiment was designed with the purpose of verifying bleaching in the larvae of three different host organisms associated with Symbiodinium A-F. Therefore we acquired broodstock for each host, spawned them and cultured the larvae, offered the Symbiodinium clades, manipulated three different temperature treatments, took samples and performed fluorimetric analysis.

Symbiodinium culture

Symbiodinium cultures (ITS2 types A1, B1, C1, D1, E1 and F1) were maintained in f/2 medium (Guillard and Ryther, 1962) with the addition of streptomycin $\left(0.5 \mathrm{~g} \mathrm{~L}^{-1}\right)$ and penicillin $\left(1.0 \mathrm{~g} \mathrm{~L}^{-1}\right)$. Cultures were kept at $23^{\circ} \mathrm{C}$, with a photon flux of $100 \mu \mathrm{E} \mathrm{m}^{-2} \mathrm{~s}^{-1}$ in a photoperiod of $12 \mathrm{~L}: 12 \mathrm{D}$.

\section{Broodstock maintenance and spawning}

The three hosts selected for this experiment were i) Mussismilia hispida, a colonial scleractinian coral endemic from Brazil, ii) Berghia stephanieae, a stenophagous nudibranch that feeds exclusively on Aiptasia anemones, from where they acquire Symbiodinium (Leal et al., 2012) and iii) Tridacna crocea, the smallest species of giant clam. All hosts are simultaneous hermaphrodites and acquire symbionts horizontally (Carroll and Kempf, 1990; Neves and Pires, 2002; Mies et al., 2012). Broodstock for all hosts were kept in water conditions that simulated tropical reefs, with temperature at $26^{\circ} \mathrm{C}$, specific gravity at $1,024 \mathrm{~kg} \mathrm{~m}^{-3}$ and nutrients at undetectable levels. Five $M$. hispida colonies $(18.5 \pm 4.4 \mathrm{~cm}$ in approximate diameter) were collected at the Recife 
de Fora (16 $25^{\prime}$ 'S , 38 $\left.59^{\prime} \mathrm{W}\right)$ in northeastern Brazil, near the Abrolhos Reefs, and kept in semi-closed tanks. Natural spawns were collected from tanks in September 2015 and gamete bundles were collected immediately after release. They were subsequently fertilized in 60-L round tubs and cultured until planulae reached four days postfertilization (PF). Daily water changes of $90 \%$ were performed. Eighty-five $B$. stephanieae individuals $(1.6 \pm 0.1 \mathrm{~cm}$ in length) were kept in two $60-\mathrm{L}$ round tubs in a recirculating aquaria system of $250 \mathrm{~L}$. Broodstock was heavily fed with 100 Aiptasia sp. individuals and egg masses produced were collected with a plastic pipette in the next morning. Egg masses were kept under strong aeration for 10 days to stimulate the release of veliger larvae (Carroll and Kempf, 1990). Tridacna crocea broodstock $(n=10$, $7.6 \pm 0.9 \mathrm{~cm}$ in shell length) was imported from Vietnam and kept in a 350-L recirculating system. Induced spawning was performed by the intragonadal injection of $1.0 \mathrm{~mL}$ of a serotonin solution (5-hydroxytryptamine, $1.0 \mathrm{~g} \mathrm{~L}^{-1}$ ). Spawned gametes were fertilized in a volumetric ratio of 1:200 (sperm:oocyte) to avoid polyspermy (Heslinga et al., 1990) and placed in 60-L round tubs with daily water changes of 50\%. Cultures were kept until all larvae had attained the veliger stage, at $72 \mathrm{~h} \mathrm{PF}$.

\section{Larval cultures, Symbiodinium offering, temperature manipulation and sampling}

Host larvae were stocked in 1.2-L plankton kreisels containing filtered seawater. Planulae of $M$. hispida (4 days PF) were stocked at 1.2 larva $\mathrm{mL}^{-1}$, B. stephanieae veligers (10 days PF) at $1.2 \mathrm{~mL}^{-1}$ and $T$. crocea veligers (3 days $\mathrm{PF}$ ) at $2.0 \mathrm{~mL}^{-1}$. Three groups of seven kreisels were used for the larvae of each host. To each group, Symbiodinium cultures (A-F) were offered separately at a final concentration of $10^{3}$ cells $\mathrm{mL}^{-1}$, with symbionts being withheld in the remainder kreisel (control group). The three groups were maintained in a water bath at $26^{\circ} \mathrm{C}$ at the time of symbiont offering. At $12 \mathrm{~h}$ after the offering of symbionts, a water change of $100 \%$ was performed in all kreisels in order to remove Symbiodinium cells that had not been acquired and symbiont acquisition was recorded. The temperature of the water baths for the three groups was then increased to 26,29 and $32^{\circ} \mathrm{C}$, over a 6-h period (Fig. 1). Samples of 150 larvae were then taken at $0,12,24,48$ and $72 \mathrm{~h}$ post-temperature increase (PTI) for size measurements and fluorimetric analysis. 

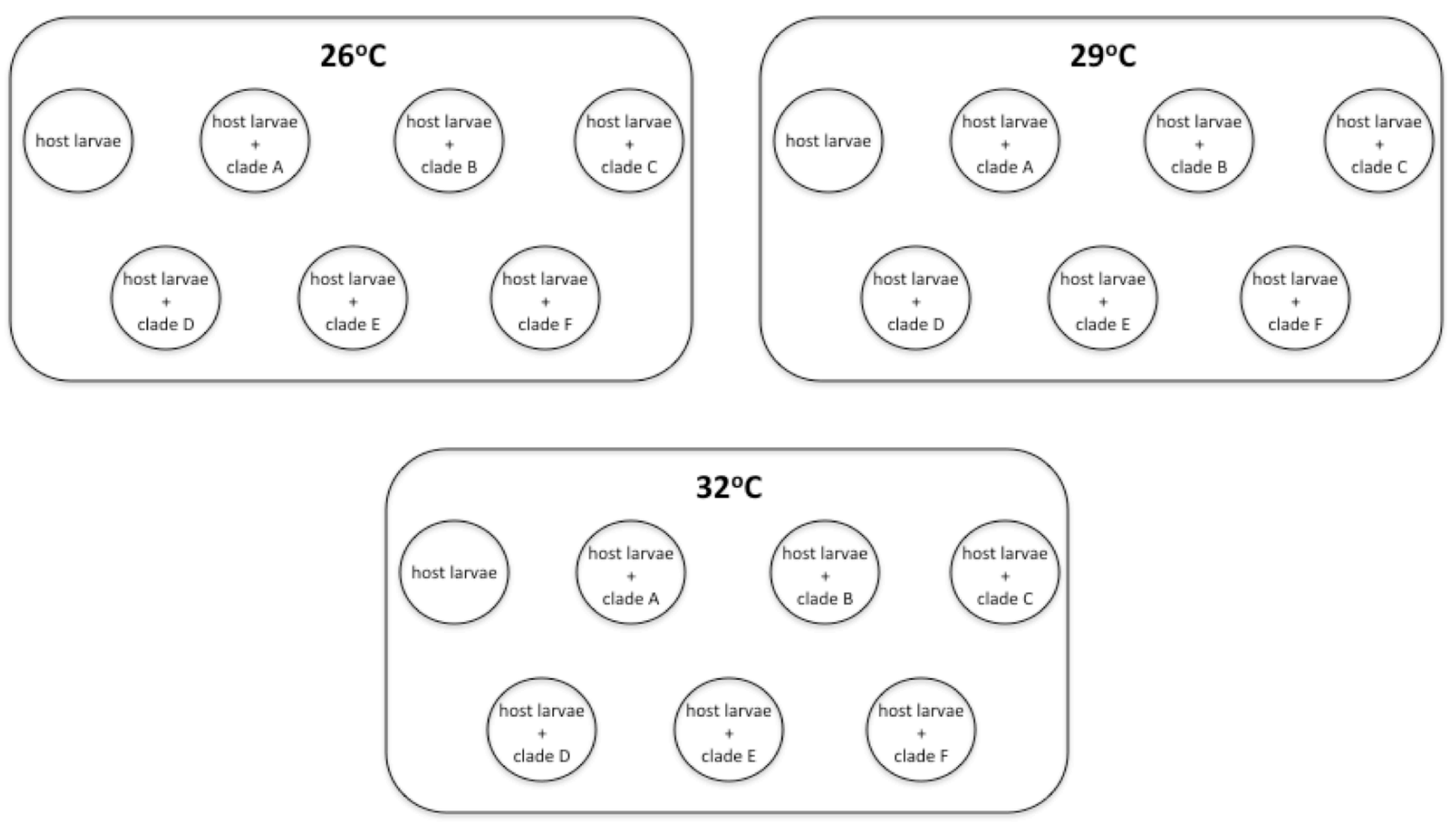

Fig. 1 Experimental design for bleaching in Mussimilia hispida (scleractinian coral), Berghia stephanieae (nudibranch) and Tridacna crocea (giant clam) larvae associated with Symbiodinium clades A-F: for each host, larvae were stocked in seven plankton kreisels, one for host larvae associated each Symbiodinium clade and a control group (aposymbiotic larvae), in water baths at 26,29 and $32^{\circ} \mathrm{C}$.

\section{Fluorimetric analysis}

Collected samples were pelleted in a centrifuge at $6,000 \mathrm{~g}$ for 2 minutes. The supernatant was discarded and sample mas macerated by the use of glass beads, a mortar and a pestle. Chlorophyll- $a$ (chl-a) extraction was performed in the dark, with acetone $(90 \%)$ and refrigeration at $4^{\circ} \mathrm{C}$ for 24 hours, as according to Wasmund et al. (2006). Samples were read in a 10-AU Turner Fluorometer and chlorophyll-a concentration was calculated according to the procedures in Welschmeyer (1994).

\section{Statistical analysis}

Statistical analyses on the larval experiments were performed independently for each host larvae. A three-way ANOVA was performed to check if Symbiodinium clade, time and temperature influence on the relative change in chl-a content (taking initial and final concentrations into consideration and excluding control larvae data). To verify which clades presented significantly different relative changes in chl-a content, a one-way 
ANOVA was performed on the $72 \mathrm{~h}$ samples for the three temperatures tested (except for T. crocea, for which the $48 \mathrm{~h}$ sample was used for the $32^{\circ} \mathrm{C}$ temperature as the $72 \mathrm{~h}$ sample larvae had died), independently. Significant differences between pairs were tested with Tukey's HSD test.

\section{Results}

Symbiodinium acquisition was higher than $99 \%$ for all host larvae used in this study. While B. stephanieae and T. crocea larvae acquired a similar amount of symbionts for all clades (Table 1), M. hispida larvae acquired Symbiodinium A more than twice than most other clades. While Symbiodinium clade did not influence larval survival for all three hosts, the temperature treatments did, as mortality increased with temperature for all host larvae (Fig. 2). In fact, all T. crocea veligers at $32^{\circ} \mathrm{C}$ died before the end of the 72-h window. Similarly to survival, larval growth was not influenced by Symbiodinium clade, but by temperature as all larvae at $32^{\circ} \mathrm{C}$ presented a smaller size than larvae at $26^{\circ} \mathrm{C}$ and $29^{\circ} \mathrm{C}$ (Fig. 3). Berghia stephanieae veliger larvae did not grow during their development, until approximately $18 \mathrm{~h}$ PTI when many individuals started going through metamorphosis, discard their shells and extend their elongated body, resulting in a swift increase in size.

The change in chl-a content in Mussisimilia hispida planulae was influenced by all three factors investigated, Symbiodinium clade (three-way ANOVA, F $=47.5$, df $=5, p<$ 0.001 ), temperature (three-way ANOVA, $\mathrm{F}=242.3$, $\mathrm{df}=2, p<0.001$ ) and time (threeway ANOVA, $\mathrm{F}=251.5, \mathrm{df}=3, p<0.001$ ). All the Symbiodinium strains acquired by planulae presented similar trends, with a slight increase in chl-a at $26^{\circ} \mathrm{C}$, followed by stabilization at $29^{\circ} \mathrm{C}$ and a decrease at $32^{\circ} \mathrm{C}$ (Fig. 4). One-way ANOVA at $26^{\circ} \mathrm{C}$ showed no significant differences in the relative change of chl-a content between clades, but the results for the $29^{\circ} \mathrm{C}$ treatment show that larvae harboring clade $\mathrm{E}$ had a significantly higher chl-a loss when compared to larvae associated with the other clades (one-way ANOVA, $\mathrm{F}=251.5$, $\mathrm{df}=3, p<0.001)$. At $32^{\circ} \mathrm{C}$, larvae associated with clade A had a significantly lower bleaching rate than larvae associated with all the other clades (oneway ANOVA, $\mathrm{F}=20.3, \mathrm{df}=5, p<0.01)$. 
Table 1 Acquisition of Symbiodinium clades A-F by Mussismilia hispida (scleractinian coral), Berghia stephanieae (nudibranch) and Tridacna crocea (giant clam) larvae after 12 hours of exposure. Symbionts were not offered to control larvae.

\begin{tabular}{lccc}
\hline $\begin{array}{l}\text { Symbiodinium } \\
\text { clade }\end{array}$ & \multicolumn{3}{c}{ Symbiodinium cells acquired } \\
\hline & M. hispida & B. stephanieae & T. crocea \\
Control & $0.0 \pm 0.0$ & $0.0 \pm 0.0$ & $0.0 \pm 0.0$ \\
A & $77.1 \pm 20.1$ & $18.1 \pm 2.0$ & $19.1 \pm 5.5$ \\
B & $40.0 \pm 9.9$ & $14.5 \pm 2.3$ & $17.7 \pm 6.7$ \\
C & $33.4 \pm 7.8$ & $15.4 \pm 1.1$ & $20.0 \pm 4.5$ \\
D & $29.1 \pm 11.1$ & $14.4 \pm 2.9$ & $22.5 \pm 8.7$ \\
E & $21.1 \pm 5.5$ & $13.9 \pm 2.4$ & $15.6 \pm 8.8$ \\
F & $30.1 \pm 9.0$ & $15.0 \pm 3.0$ & $13.3 \pm 5.7$ \\
\hline
\end{tabular}

In the case of B. stephanieae, time (three-way ANOVA, $\mathrm{F}=220.2, \mathrm{df}=3, p<$ 0.01 ) and temperature (three-way ANOVA, $\mathrm{F}=164.7 \mathrm{df}=2, p<0.01$ ) influenced the change in chl-a content in larvae and juveniles, but no significant effect by Symbiodinium clade was detected. Furthermore, it was detected during the experiments that the majority of Symbiodinium cells inside larvae and juvenile tissues, independently of clade, were partially digested. At $72 \mathrm{~h}$ PTI for the $32^{\circ} \mathrm{C}$ treatment, nearly zero Symbiodinium cells were found in juvenile B. stephanieae.

Changes in the chl-a content in $T$. crocea veliger larvae was, likewise for $M$. hispida, affected by all three factors: Symbiodinium clade (three-way ANOVA, F = 76.6, $\mathrm{df}=5, p<0.01$ ), temperature (three-way ANOVA, $\mathrm{F}=112.7, \mathrm{df}=2, p<0.01$ ) and time (three-way ANOVA, $\mathrm{F}=187.6, \mathrm{df}=3, p<0.01$ ). Again similar to M. hispida, all the Symbiodinium clades presented similar trends, with no change in chl-a content at $26^{\circ} \mathrm{C}$, a slight bleaching at $29^{\circ} \mathrm{C}$ and a stronger bleaching followed by mortality at $32^{\circ} \mathrm{C}$ (Figs. 3 and 4). At $29^{\circ} \mathrm{C}$, larvae associated with Symbiodinium clade A were the only ones not to present a decrease in chl-a, statistically different from larvae harboring other clades (one-way ANOVA, $\mathrm{F}=11.2$, df $=5, p<0.01$ ). At $32^{\circ} \mathrm{C}$, larvae containing Symbiodinium clade A also had a significantly lower loss of chl-a when compared to larvae associated with all other clades, while clades $\mathrm{C}$ and D presented lower chl-a loss when compared to clades B, E and F (one-way ANOVA, F = 90.7, $\mathrm{df}=5, p<0.01$ ). 

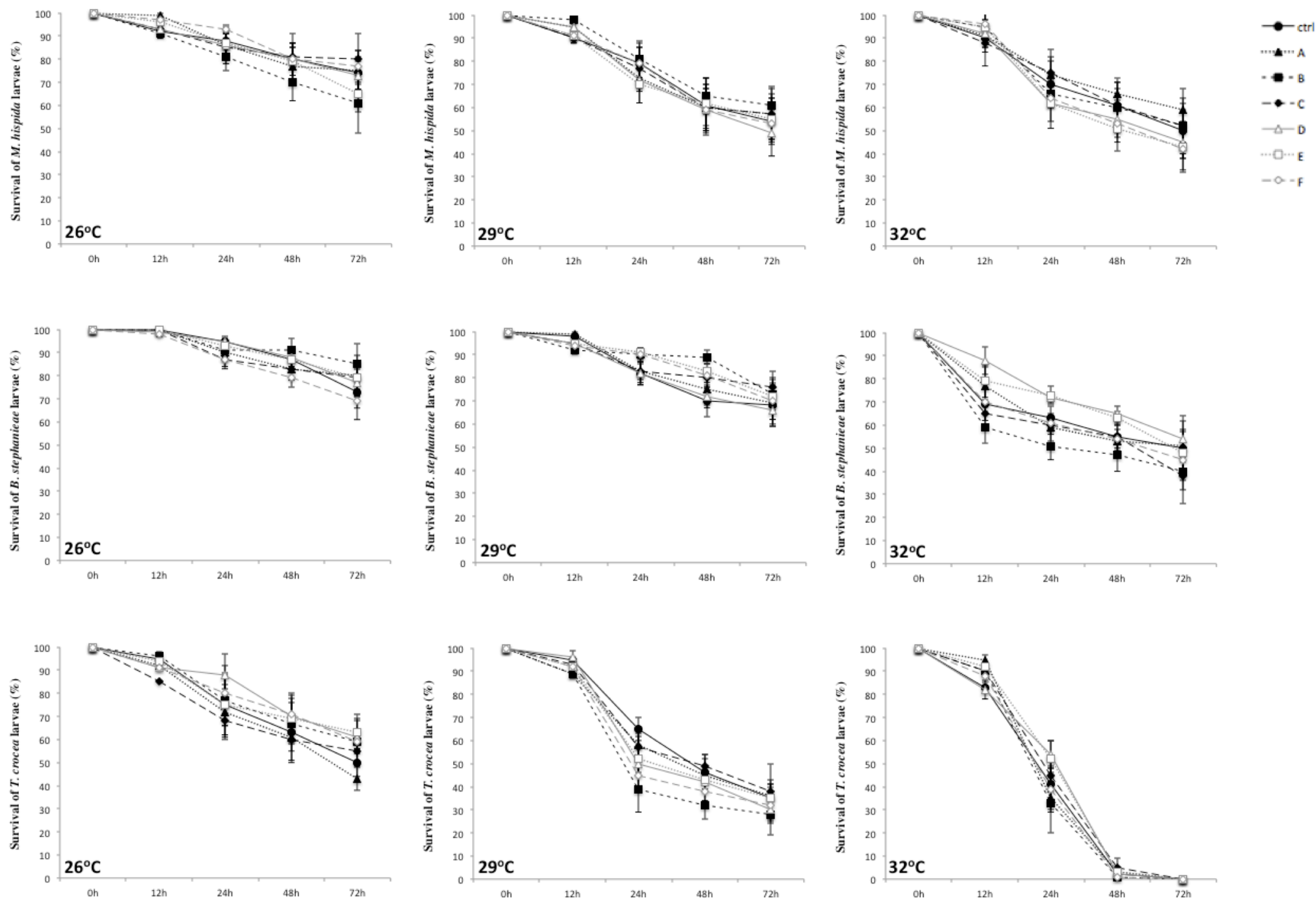

Fig. 2 Survival curves for Mussimilia hispida (scleractinian coral), Berghia stephanieae (nudibranch) and Tridacna crocea (giant clam) larvae associated with Symbiodinium clades A-F during a 72-h exposure to 26,29 and $32^{\circ} \mathrm{C}$. Symbionts were not offered to the control larvae. 

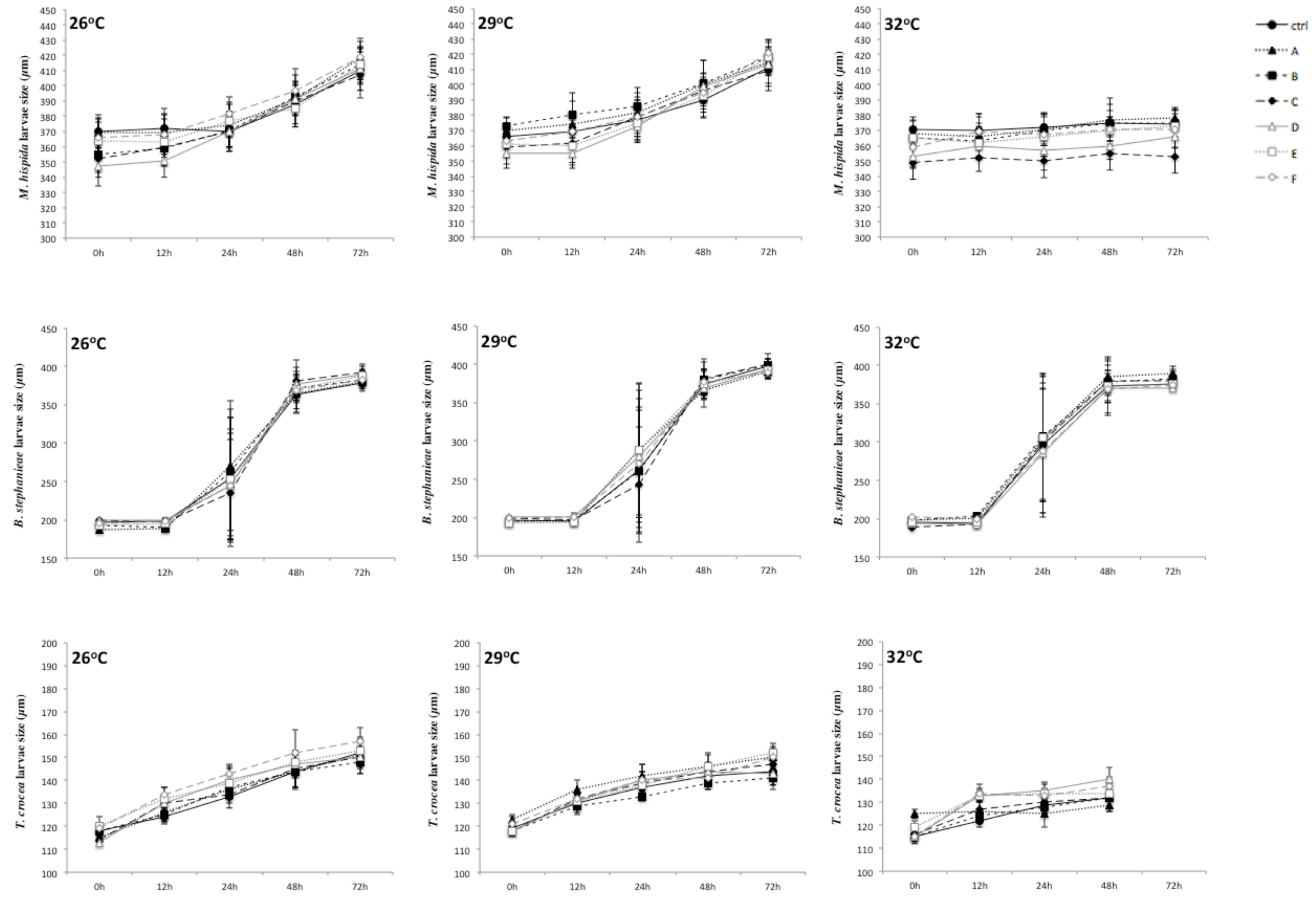

Fig. 3 Growth curves for Mussimilia hispida (scleractinian coral), Berghia stephanieae (nudibranch) and Tridacna crocea (giant clam) larvae associated with Symbiodinium clades A-F during a 72-h exposure to 26,29 and $32^{\circ} \mathrm{C}$. Data were not collected for $T$. crocea at $72 \mathrm{~h}$ at $32^{\circ} \mathrm{C}$ because larvae died. Symbionts were not offered to the control larvae. 

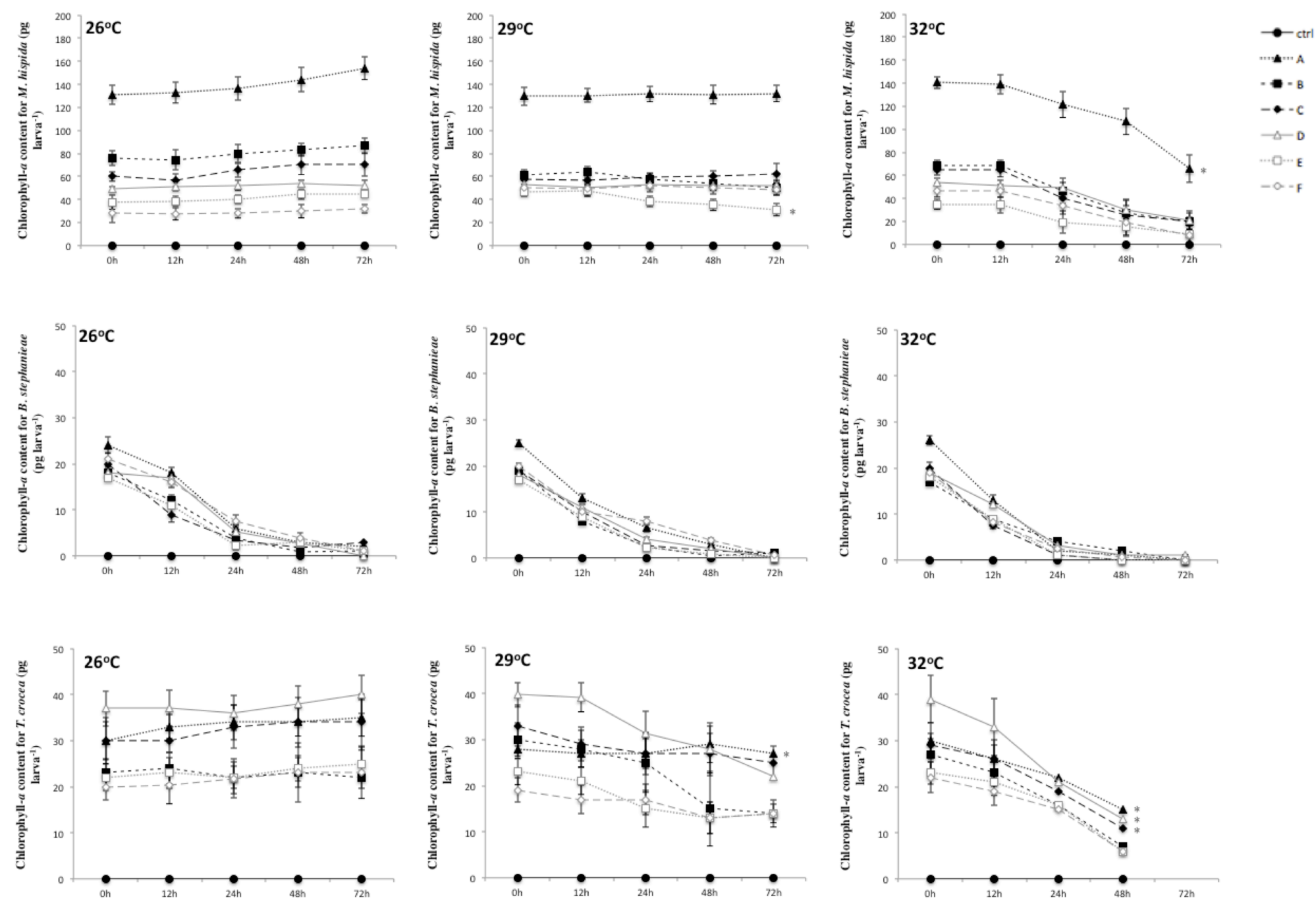

Fig. 4 Chlorophyll- $a$ content in Mussimilia hispida (scleractinian coral), Berghia stephanieae (nudibranch) and Tridacna crocea (giant clam) larvae associated with Symbiodinium clades A-F during a 72-h exposure to 26, 29 and $32^{\circ} \mathrm{C}$. Data were not collected for $T$. crocea at $72 \mathrm{~h}$ at $32^{\circ} \mathrm{C}$ because larvae died. Symbionts were not offered to the control larvae. Asterisks denote groups statistically different for relative change in chlorophyll- $a$ content. 


\section{Discussion}

Coral reefs are critically threatened by the increase in surface seawater temperature. It has been predicted that coral-dominated ecosystems are likely to disappear if the current trends in impact, mainly bleaching, are not mitigated immediately (Hoegh-Guldberg, 1999; Hoegh-Guldberg et al., 2007). While the bleaching phenomenon has been widely investigated in adult coral reef organisms, it is still very poorly understood for larval stages of development. Therefore, our experiment investigated if bleaching occurs in larval stages and if associated Symbiodinium clades respond differently to thermal stress. We used loss of chlorophyll- $a$ as a proxy for Symbiodinum loss, in similar fashion to Tanaka et al. (2014).

Our results confirmed that bleaching does occur not only in scleractinian coral larvae, but also in giant clam larvae. The bleaching threshold for Mussismilia hispida larvae seems to be at $29^{\circ} \mathrm{C}$, while for Tridacna crocea it may be even lower (Fig. 4). This is in between the thresholds of 28 and $30^{\circ} \mathrm{C}$ reported for the larvae of Porites astreoides (Edmunds et al., 2005) and Acropora millepora (Mieog et al., 2009), respectively. In the case of the nudibranch Berghia stephanieae, while our results show temperature-dependent decrease in chlorophyll- $a$ content, it is not possible to determine if this is related to bleaching, symbiont digestion or the combination of both. In fact it is questionable if a mutualistic symbiosis is at work between this species and Symbiodinium (Mies et al., this thesis chapter 2).

The major finding in this study is that Symbiodinium clades A-F present different bleaching rates when associated with coral reef larvae (Fig. 4). Clade A presented the lowest bleaching rates in both coral and giant clam larvae, with clades $\mathrm{C}$ and $\mathrm{D}$ following as the most resistant types. This differs from the several reports for adult hosts that clade $\mathrm{D}$ is the most thermo-tolerant strain, that not only endures higher temperatures for longer periods, but also behave as opportunistic in the reinfection of bleached organisms (Chen et al., 2003; van Oppen et al., 2005; Abrego et al., 2009; Mieog et al., 2009; Ladner et al., 2012). Differences were presented by Symbiodinium clades already at initial larval infection. Our results show that $M$. hispida acquired Symbiodinium A in much higher quantities (Table 1). While there is debate on whether is there symbiont-specificity at initial infection (Belda-Baillie et al., 1999; Little et al., 
2004; Cumbo et al., 2012), our results seem to point to a preference by M. hispida. The better performance by Symbiodinium clade A and C in this study may be related to homology, as both clades are naturally found in M. hispida (Picciani et al., 2016) and T. crocea (DeBoer et al., 2012). This is in contrast with the results we obtained for the less-abundant clades $\mathrm{E}$ and $\mathrm{F}$, which usually presented higher bleaching rates and lower concentrations in host larvae (Fig. 4). Furthermore, Symbiodinium clade A associated with $M$. hispida and T. crocea has been shown to differentially express a symbiosisspecific gene and produce higher amount of fatty acids that are typically translocated to the host (Mies et al., this thesis chapter 3).

The different response by some clades and the fact that no differences were found in survival for larvae associated with clades A-F may also contribute to the debate on the effect of reactive oxygen species (ROS) in coral reef larvae. It has been reported that, under increased temperature, the presence of symbionts may reduce larval survival due to the relatively higher production of ROS (Yakovleva et al., 2009; Schnitzler et al., 2012). This event reduces larval survival as its consequences include DNA damage and high rates of enzymatic antioxidant activity (Yakovleva et al., 2009; Nesa et al., 2012). Therefore, it has been suggested that bleaching may be important for larval survival at higher temperatures (Weis, 2008; Yakovleva et al., 2009), as symbiont presence, while may increase host fitness (Weis et al., 2001), is not necessary for successful settlement and metamorphosis for many coral species (Morse et al., 1996). However, it has been shown that symbiont presence is an important stimulating factor for settlement and metamorphosis (Vermeij et al., 2013). The scenario that symbiont presence decreases survival would lead to a higher mortality of $M$. hispida larvae associated with Symbiodinium clade A1, which in this study presented statistically significant lower bleaching rates. However, such mortality was not found and relates to the few studies that have reported that, associated with homologous clades (including A1), both coral adults and larvae under thermal stress (as high as $32^{\circ} \mathrm{C}$ ) did not show an increase in ROS production or higher mortality (McGinty et al., 2012; Haryanti et al., 2015). Therefore, it is relevant to further investigate the relationship between coral reef larvae and Symbiodinium type, especially since it may have an important role in recruitment.

This study has shown that temperature, time and Symbiodinium strain are critical elements that directly influence on the bleaching phenomenon in coral reef larvae. Our 
major contribution is to perhaps raise awareness that bleaching events affect not only the adult hosts, but also the larval forms, which are crucial for the successful recruitment and maintenance of coral reef biodiversity.

\section{Acknowledgements}

We would like to thank Mary Alice Coffroth for supplying the Symbiodinium cultures, Flávia SaldanhaCorrêa for kindly keeping them, the Coral Vivo Institute staff and Salvador Gaeta for the use of his facilities and equipment. This work was supported by Projeto Coral Vivo and sponsored by Petrobrás (Programa Petrobrás Socioambiental) and Arraial d'Ajuda Eco Parque. PYGS acknowledges grants 302526/2012-9 and 2010/20350-8 from CNPq and FAPESP.

\section{Author contributions}

M.M. designed the experiment, M.M. performed the experiment, C.B.C., D.O.P. E.N.C. and M.P. contributed with infrastructure/material/technical support, M.M. and A.Z.G. analyzed the data and M.M. and P.Y.G.S. wrote the manuscript. 


\section{CONCLUSIONS}

The symbiotic relationship between Symbiodinium and their host organisms has been widely investigated (Stat et al., 2006; Venn et al., 2008; Weis et al., 2008; Davy et al., 2012). However, very little is known about this association for hosts still in their larval development (Mies et al., this thesis chapter 1). This lack of information, especially on metabolite exchange and differential gene expression, questions if there is a mutualistic relationship between Symbiodinium and coral reef larvae. In order to improve our understanding of the association between these organisms, this thesis performed molecular, biochemical and climate change-related experiments on the association between six different Symbiodinium clades (A-F) and coral (Mussismilia hispida), gastropod (Berghia stephanieae) and giant clam (Tridacna crocea) larvae, while also performing a review on the subject and placing our findings in perspective.

Our major findings show that a symbiosis-specific gene is expressed by Symbiodinium clade A1 associated with coral and giant clam larvae, and that this gene, the $\mathrm{H}^{+}$-ATPase, is a relevant and perhaps the only currently available marker for the symbiotic state of Symbiodinium (Mies et al., this thesis chapter 2). We have also shown that homologous Symbiodinium clades associated with coral and giant clam larvae produce a higher amount of a fatty acid that is usually translocated from symbiont to host (Mies et al., this thesis chapter 3), while also being more resistant to bleaching (Mies et al., this thesis chapter 4). Finally, we show compelling evidence that there is no mutualism between Symbiodinium and the aeolid nudibranch B. stephanieae (Mies et al., this thesis chapters 2-4).

The implications of our findings are relevant for coral reef ecology, as the current knowledge on the mechanisms involved in symbiosis establishment has been strengthened. Furthermore, we have identified associations between certain larval hosts and certain Symbiodinium clades that confer higher larval fitness, which can be crucial for successful settlement and recruitment. Aquaculture and restocking programs are currently being employed for coral reef restoration (Pomeroy et al., 2006; Guest et al., 2010), and our results can also provide insights on culture techniques, as well as suggest 
when and which symbionts may be offered to larvae. The results presented in the thermal stress experiment (chapter 4) also confirm that not only adult reef inhabitants suffer bleaching, but larvae do as well. This has implications for the current climate change scenario, as coral-dominated reefs may disappear in the coming decades due to ocean acidification and global warming (Hoegh-Guldberg, 1999; Hughes et al., 2003; Pandolfi et al., 2003; Hoegh-Guldberg et al., 2007; Baker et al., 2008). The more robust associations reported in chapter 4 may perhaps aid in the mitigation of climate change impacts and also on the predictions and assessments of future scenarios. 


\section{REFERENCES}

Abrego D, van Oppen MJH, Willis BL (2009) Highly infectious symbiont dominates initial uptake in coral juveniles. Molecular Ecology 18:3518-3531.

Achituv Y, Benayahu Y, Hanania J (1992) Planulae brooding and acquisition of zooxanthellae in Xenia macrospiculata (Cnidaria: Octocorallia). Helgoländer Meeresuntersuchungen 46:301-310.

Adams LM, Cumbo VR, Takabayashi M (2009) Exposure to sediment enhances primary acquisition of Symbiodinium by asymbiotic coral larvae. Marine Ecology Progress Series 377:149-156.

Ahmadian R, Burghardt I, Shepherd UL (2016) Embryonic development of the solarpowered nudibranch Phyllodesmium lizardensis (Gastropoda: Nudibranchia). Molluscan Research 36:285-289.

Alcazar SN, Solis EP, Alcala AC (1987) Serotonin-induced spawning and larval rearing of the China clam, Hippopus porcellanus Rosewater (Bivalvia: Tridacnidae). Aquaculture 66:359-368.

Allemand D, Furla P, Bénazet-Tambutté S (1998) Mechanisms of carbon acquisition for endosymbiont photosynthesis in Anthozoa. Canadian Journal of Botany 76:925941.

Arai I, Kato M, Heyward A, Ikeda Y, lizuka T, Maruyama T (1993) Lipid composition of positively buoyant eggs of reef building corals. Coral Reefs 12:71-75.

Aranda M, Li Y, Liew YJ, Baumgarten S, Simakov O, Wilson M, Piel J, Ashoor H, Bougouffa S, Bajic V, Ryu T, Ravasi T, Bayer T, Micklem G, Kim H, Bhak J, LaJeunesse TC, Voolstra CR (2016) Genomes of coral dinoflagellate symbionts highlight evolutionary adaptations conducive to a symbiotic lifestyle. Scientific Reports. doi: 10.1038/srep39734.

Bachok Z, Mfilinge P, Tsuchiya M (2006) Characterization of fatty acid composition in healthy and bleached corals from Okinawa, Japan. Coral Reefs 25:545-554.

Baird AH, Cumbo VR, Leggat W, Rodriguez-Lanetty M (2007) Fidelity and flexibility in coral symbioses. Marine Ecology Progress Series 347:307-309.

Baird AH, Guest JR, Willis BL (2009) Systematic and biogeographical patterns in the reproductive biology of scleractinian corals. Annual Review of Ecology, Evolution, and Systematics 40:551-571.

Baker AC (2003) Flexibility and specificity in coral-algal symbiosis: diversity, ecology, and biogeography of Symbiodinium. Annual Review of Ecology, Evolution, and Systematics 34:661-689.

Baker AC, Glynn PW, Riegl B (2008) Climate change and coral reef bleaching: an ecological assessment of long-term impacts, recovery trends and future outlook. Estuarine, Coastal and Shelf Science 80:435-471.

Banaszak AT, García Ramos M, Goulet TL (2013) The symbiosis between the gastropod Strombus gigas and the dinoflagellate Symbiodinium: an ontogenic journey from mutualism to parasitism. Journal of Experimental Marine Biology and Ecology 449:358-365.

Barneah O, Brickner I, Hooge M, Weis VM, Benayahu Y (2007a) First evidence of maternal transmission of algal endosymbionts at an oocyte stage in a triploblastic 
host, with observations on reproduction in Waminoa brickneri (Acoelomorpha). Invertebrate Biology 126:113-119.

Barneah O, Brickner I, Hooge M, Weis VM, LaJeunesse TC, Benayahu Y (2007b)

Three party symbiosis: acoelomorph worms, corals and unicellular algal symbionts in Eilat (Red Sea). Marine Biology 151:1215-1223.

Barneah O, Weis VM, Perez S, Benayahu Y (2004) Diversity of dinoflagellate symbionts in Red Sea soft corals: mode of symbiont acquisition matters. Marine Ecology Progress Series 275:89-95.

Baumgarten S, Bayer T, Aranda M, Liew Y, Carr A, Micklem G, Voolstra C (2013) Integrating microRNA and mRNA expression profiling in Symbiodinium microadriaticum, a dinoflagellate symbiont of reef-building corals. BMC Genomics 14:704.

Baumgarten S, Simakov O, Esherick LY, Liew YJ, Lehnert EM, Michell CT, Li Y, Hambleton EA, Guse A, Oates ME, Gough J, Weis VM, Aranda M, Pringle JR, Voolstra CR (2015) The genome of Aiptasia, a sea anemone model for coral symbiosis. Proceedings of the National Academy of Sciences of the United States of America 112:201513318.

Bay LK, Cumbo VR, Abrego D, Kool JT, Ainsworth TD, Willis BL (2011) Infection dynamics vary between Symbiodinium types and cell surface treatments during establishment of endosymbiosis with coral larvae. Diversity 3:356-374.

Bayer T, Aranda M, Sunagawa S, Yum LK, DeSalvo MK, Lindquist E, Coffroth MA, Voolstra CR, Medina M (2012) Symbiodinium transcriptomes: genome insights into the dinoflagellate symbionts of reef-building corals. PLOS ONE 7:e35269.

Beckvar N (1981) Cultivation, spawning, and growth of the giant clams Tridacna gigas, T. derasa, and T. squamosa in Palau, Caroline Islands. Aquaculture 24:21-30.

Belda-Baillie CA, Baillie BK, Maruyama T (2002) Specificity of a model cnidariandinoflagellate symbiosis. Biological Bulletin 202:74-85.

Belda-Baillie CA, Sison M, Silvestre V, Villamor K, Monje V, Gomez ED, Baillie BK (1999) Evidence for changing symbiotic algae in juvenile tridacnids. Journal of Experimental Marine Biology and Ecology 241:207-221.

Ben-David-Zaslow R, Benayahu Y (1998) Competence and longevity in planulae of several species of soft corals. Marine Ecology Progress Series 163:235-243.

Benayahu Y, Achituv Y, Berner T (1988) Embryogenesis and acquisition of algal symbionts by planulae of Xenia umbellata (Octocorallia: Alcyonacea). Marine Biology 100:93-101.

Benayahu Y, Weil D, Malik Z (1992) Entry of algal symbionts into oocytes of the coral Litophyton arboreum. Tissue and Cell 24:473-482.

Bergé JP, Barnathan G (2005) Fatty acids from lipids of marine organisms: molecular biodiversity, roles as biomarkers, biologically active compounds, and economical aspects. Advances in Biochemical Engineering/Biotechnology 96:49-125.

Berkelmans R, van Oppen MJH (2006) The role of zooxanthellae in the thermal tolerance of corals: a "nugget of hope" for coral reefs in an era of climate change. Proceedings of the Royal Society B: Biological Sciences 273:2305-12.

Bertucci A, Tambutté E, Tambutté S, Allemand D, Zoccola D (2010) Symbiosisdependent gene expression in coral-dinoflagellate association: cloning and characterization of a P-type H+-ATPase gene. Proceedings of the Royal Society B: Biological Sciences 277:87-95.

Braley RD (1985) Serotonin-induced spawning in giant clams (Bivalvia: Tridacnidae). Aquaculture 47:321-325.

Brander LM, Van Beukering P, Cesar HSJ (2007) The recreational value of coral reefs: 
a meta-analysis. Ecological Economics 63:209-218.

Brown BE (1997) Adaptations of reef corals to physical environmental stress. Advances in Marine Biology 31:221-299.

Bucher M, Wolfowicz I, Voss PA, Hambleton EA, Guse A (2016) Development and symbiosis establishment in the cnidarian endosymbiosis model Aiptasia sp. Scientific Reports. doi: doi:10.1038/srep19867.

Budge SM, Iverson SJ, Koopman HN (2006) Studying trophic ecology in marine ecosystems using fatty acids: a primer on analysis and interpretation. Marine Mammal Science 22:759-801.

Burghardt I, Evertsen J, Johnsen G, Wägele H (2005) Solar powered seaslugs mutualistic symbiosis of aeolid Nudibranchia (Mollusca, Gastropoda, Opisthobranchia) with Symbiodinium. Symbiosis 38:227-250.

Burghardt I, Wägele H (2014) The symbiosis between the "solar-powered" nudibranch Melibe engeli Risbec, 1937 (Dendronotoidea) and Symbiodinium sp.

(Dinophyceae). Journal of Molluscan Studies 80:508-517.

Burriesci MS, Raab TK, Pringle JR (2012) Evidence that glucose is the major transferred metabolite in dinoflagellate-cnidarian symbiosis. Journal of Experimental Biology 215:3467-3477.

Bythell JC, Douglas a. E, Sharp V a., Searle JB, Brown BE (1997) Algal genotype and photoacclimatory responses of the symbiotic alga Symbiodinium in natural populations of the sea anemone Anemonia viridis. Proceedings of the Royal Society B: Biological Sciences 264:1277-1282.

Carlos AA, Baillie BK, Maruyama T (2000) Diversity of dinoflagellate symbionts (zooxanthellae) in a host individual. Marine Ecology Progress Series 195:93-100.

Carroll DJ, Kempf SC (1990) Laboratory culture of the aeolid nudibranch Berghia verrucicornis (Mollusca, Opisthobranchia): some aspects of its development and life history. Biological Bulletin 179:243-253.

Cesar HS (2000) Coral reefs: their functions, threats and economical value. In: Cesar HS (ed) Collected essays on the economics of coral reefs. Cordio, Kalmar, pp 14 39.

Chen CA, Lam KK, Nakano Y, Tsai WS (2003) A stable association of the stresstolerant zooxanthellae, Symbiodinium clade D, with the low-temperature-tolerant coral, Oulastrea crispata (Scleractinia: Faviidae) in subtropical non-reefal coral communities. Zoological Studies 42:540-550.

Coffroth MA, Santos SR (2005) Genetic diversity of symbiotic dinoflagellates in the genus Symbiodinium. Protist 156:19-34.

Colombo-Pallotta MF, Rodríguez-Román A, Iglesias-Prieto R (2010) Calcification in bleached and unbleached Montastraea faveolata: Evaluating the role of oxygen and glycerol. Coral Reefs 29:899-907.

Connell JH (1978) Diversity in tropical rain forests and coral reefs. Science 199:13021310.

Cooper TF, Ulstrup KE, Dandan SS, Heyward AJ, Kühl M, Muirhead A, O'Leary R a, Ziersen BEF, Van Oppen MJH (2011) Niche specialization of reef-building corals in the mesophotic zone: metabolic trade-offs between divergent Symbiodinium types. Proceedings of the Royal Society B: Biological Sciences 278:1840-1850.

Cumbo VR, Baird AH, van Oppen MJH (2012) The promiscuous larvae: flexibility in the establishment of symbiosis in corals. Coral Reefs 32:111-120.

Dalsgaard J, St John M, Kattner G, Müller-Navarra D, Hagen W (2003) Fatty acid trophic markers in the pelagic marine environment. Advances in Marine Biology 46:225-340. 
Davy SK, Allemand D, Weis VM (2012) Cell biology of cnidarian-dinoflagellate symbiosis. Microbiology and Molecular Biology Reviews 76:229-261.

deBoer ML, Krupp DA, Weis VM (2007) Proteomic and transcriptional analyses of coral larvae newly engaged in symbiosis with dinoflagellates. Comparative Biochemistry and Physiology - Part D: Genomics and Proteomics 2:63-73.

DeBoer TS, Baker AC, Erdmann M V., Ambariyanto, Jones PR, Barber PH (2012) Patterns of Symbiodinium distribution in three giant clam species across the biodiverse Bird's Head region of Indonesia. Marine Ecology Progress Series 444:117-132.

Dionísio G, Rosa R, Leal MC, Cruz S, Brandão C, Calado G, Serôdio J, Calado R (2013) Beauties and beasts: a portrait of sea slugs aquaculture. Aquaculture 408409:1-14.

Dunn SR, Weis VM (2009) Apoptosis as a post-phagocytic winnowing mechanism in a coral-dinoflagellate mutualism. Environmental Microbiology 11:268-276.

Edmunds PJ, Gates RD, Leggat W, Hoegh-Guldberg O, Allen-Requa L (2005) The effect of temperature on the size and population density of dinoflagellates in larvae of the reef coral Porites astreoides. Invertebrate Biology 124:185-193.

Erwin PM, Szmant AM (2010) Settlement induction of Acropora palmata planulae by a GLW-amide neuropeptide. Coral Reefs 29:929-939.

Figueiredo J, Baird AH, Cohen MF, Flot JF, Kamiki T, Meziane T, Tsuchiya M, Yamasaki H (2012) Ontogenetic change in the lipid and fatty acid composition of scleractinian coral larvae. Coral Reefs 31:613-619.

Fitt WK, Brown BE, Warner ME, Dunne RP (2001) Coral bleaching: interpretation of thermal tolerance limits and thermal thresholds in tropical corals. Coral Reefs 20:51-65.

Fitt WK, Fisher CR, Trench RK (1984) Larval biology of tridacnid clams. Aquaculture 39:181-195.

Fitt WK, Fisher CR, Trench RK (1986) Contribution of the symbiotic dinoflagellate Symbiodinium microadriaticum to the nutrition, growth and survival of larval and juvenile tridacnid clams. Aquaculture 55:5-22.

Fitt WK, Trench RK (1981) Spawning, development, and acquisition of zooxanthellae by Tridacna squamosa (Mollusca, Bivalvia). Biological Bulletin 161:213-235.

Fransolet D, Roberty S, Plumier JC (2012) Establishment of endosymbiosis: The case of cnidarians and Symbiodinium. Journal of Experimental Marine Biology and Ecology 420-421:1-7.

Freudenthal HD (1962) Symbiodinium gen. nov. and Symbiodinium microadriaticum sp. nov., a zooxanthella: taxonomy, life cycle, and morphology. The Journal of Protozoology 9:45-52.

Furla P, Allemand D, Shick JM, Ferrier-Pagès C, Richier S, Plantivaux A, Merle PL, Tambutté S (2005) The symbiotic anthozoan: a physiological chimera between alga and animal. Integrative and Comparative Biology 45:595-604.

Glynn PW (1996) Coral reef bleaching: facts, hypotheses and implications. Global Change Biology 2:495-509.

Goiran C, Al-Moghrabi S, Allemand D, Jaubert J (1996) Inorganic carbon uptake for photosynthesis by the symbiotic coral/dinoflagellate association: I. Photosynthetic performances of symbionts and dependence on sea water bicarbonate. Journal of Experimental Marine Biology and Ecology 199:207-225.

Gordon BR, Leggat W (2010) Symbiodinium - invertebrate symbioses and the role of metabolomics. Marine Drugs 8:2546-2568.

Goulet TL (2006) Most corals may not change their symbionts. Marine Ecology 
Progress Series 321:1-7.

Graeve M, Kattner G, Hagen W (1994) Diet-induced changes in the fatty acid composition of Arctic herbivorous copepods: experimental evidence of trophic markers. Journal of Experimental Marine Biology and Ecology 182:97-110.

Grant AJ, Rémond M, People J, Hinde R (1997) Effects of host-tissue homogenate of the scleractinian coral Plesiastrea versipora on glycerol metabolism in isolated symbiotic dinoflagellates. Marine Biology 128:665-670.

Guest JR, Heyward A, Omori M, Iwao K, Morse ANC, Boch C (2010) Rearing coral larvae for reef rehabilitation. In: Edwards AJ (ed) Reef Rehabilitation Manual. The Coral Reef Targeted Research \& Capacity Building for Management Program, St. Lucia, Australia, pp 73-98

Guillard RR, Ryther JH (1962) Studies of marine planktonic diatoms, I: Cycotella nana hustedl, and Detonula confervacea (cleve) gran. Canadian Journal of Microbiology 8:229-239.

Hackett JD, Scheetz TE, Yoon HS, Soares MB, Bonaldo MF, Casavant TL, Bhattacharya D (2005) Insights into a dinoflagellate genome through expressed sequence tag analysis. BMC Genomics 6:80.

Hambleton EA, Guse A, Pringle JR (2014) Similar specificities of symbiont uptake by adults and larvae in an anemone model system for coral biology. The Journal of experimental Biology 217:1613-1619.

Harii S, Yasuda N, Rodriguez-Lanetty M, Irie T, Hidaka M (2009) Onset of symbiosis and distribution patterns of symbiotic dinoflagellates in the larvae of scleractinian corals. Marine Biology 156:1203-1212.

Harrison PL (2011) Sexual reproduction of scleractinian corals. In: Dubinsky Z, Stambler N (eds) Coral Reefs: An Ecosystem in Transition. Springer, Heidelberg, pp 59-85.

Harrison PL, Wallace CC (1990) Reproduction, dispersal and recruitment of scleractinian corals. In: Dubinsky Z (ed) Ecosystems of the World. Elsevier, Amsterdam, pp 133-208.

Haryanti D, Yasuda N, Harii S, Hidaka M (2015) High tolerance of symbiotic larvae of Pocillopora damicornis to thermal stress. Zoological Studies 1-7.

Heslinga GA, Perron FE, Orak O (1984) Mass culture of giant clams (F. Tridacnidae) in Palau. Aquaculture 39:197-215.

Heslinga GA, Watson TC, Isamu T (eds) (1990) Giant Clam Farming. Pacific Fisheries Development Foundation (NMFS/NOAA), Honolulu.

Hikosaka-Katayama T, Koike K, Yamashita H, Hikosaka A, Koike K (2012) Mechanisms of maternal inheritance of dinoflagellate symbionts in the acoelomorph worm Waminoa litus. Zoological Science 29:559-567.

Hill M, Allenby A, Ramsby B, Schönberg C, Hill A (2011) Symbiodinium diversity among host clionaid sponges from Caribbean and Pacific reefs: evidence of heteroplasmy and putative host-specific symbiont lineages. Molecular Phylogenetics and Evolution 59:81-88.

Hirose E, Iwai K, Maruyama T (2006) Establishment of the photosymbiosis in the early ontogeny of three giant clams. Marine Biology 148:551-558.

Hoegh-Guldberg O (1999) Climate change, coral bleaching and the future of the world's coral reefs. Marine and Freshwater Research 50:839-866.

Hoegh-Guldberg O, Hinde R (1986) Studies on a nudibranch that contains zooxanthellae I. Photosynthesis, respiration and the translocation of newly fixed carbon by zooxanthellae in Pteraeolidia ianthina. Proceedings of the Royal Society B: Biological Sciences 228:493-509. 
Hoegh-Guldberg O, Mumby PJ, Hooten AJ, Steneck RS, Greenfield P, Gomez ED, Harvell CD, Sale PF, Edwards AJ, Caldeira K, Knowlton N, Eakin CM, IglesiasPrieto R, Muthiga N, Bradbury RH, Dubi A, Hatziolos ME (2007) Coral reefs under rapid climate change and ocean acidification. Science 318:1737-1742.

Hofmann DK, Fitt WK, Fleck J (1996) Checkpoints in the life-cycle of Cassiopea spp.: control of metagenesis and metamorphosis in a tropical jellyfish. International Journal of Developmental Biology 40:331-338.

Huang HJ, Wang LH, Chen WNU, Fang LS, Chen CS (2008) Developmentally regulated localization of endosymbiotic dinoflagellates in different tissue layers of coral larvae. Coral Reefs 27:365-372.

Hughes TP, Baird AH, Bellwood DR, Card M, Connolly SR, Folke C, Grosberg R, Hoegh-Guldberg O, Jackson JBC, Kleypas J, Lough JM, Marshall P, Nyström M, Palumbi SR, Pandolfi JM, Rosen B, Roughgarden J (2003) Climate change, human impacts, and the resilience of coral reefs. Science 301:929-933.

Hughes TP, Rodrigues MJ, Bellwood DR, Ceccarelli D, Hoegh-Guldberg O, McCook L, Moltschaniwskyj N, Pratchett MS, Steneck RS, Willis B (2007) Phase shifts, herbivory, and the resilience of coral reefs to climate change. Current Biology 17:360-365.

Hume BCC, Angelo CD, Smith EG, Stevens JR, Burt J, Wiedenmann J (2015) Symbiodinium thermophilum sp. nov., a thermotolerant symbiotic alga prevalent in corals of the world's hottest sea, the Persian/Arabian Gulf. Scientific Reports. doi 10.1038/srep08562.

Iglesias-Prieto R, Matta JL, Robins W a, Trench RK (1992) Photosynthetic response to elevated temperature in the symbiotic dinoflagellate Symbiodinium microadriaticum in culture. Proceedings of the National Academy of Sciences of the United States of America 89:10302-10305.

Jones AM, Berkelmans R, van Oppen MJH, Mieog JC, Sinclair W (2008) A community change in the algal endosymbionts of a scleractinian coral following a natural bleaching event: field evidence of acclimatization. Proceedings of the Royal Society B: Biological Sciences 275:1359-65.

Karako-Lampert S, Hershkovits G, Stambler N, Simon-Blecher N, Achituv Y, Dubinsky Z, Katcoff DJ (2006) Differential gene expression in Symbiodinium microadriaticum clade B following stress. Marine Biotechnology 8:268-274.

Kempf SC (1984) Symbiosis between the zooxanthella Symbiodinium (= Gymnodinium) microadriaticum (Freudenthal) and four species of nudibranchs. Biological Bulletin 166:110-126.

Kempf SC (1991) A "primitive" symbiosis between the aeolid nudibranch Berghia verrucicornis (A. Costa, 1867) and a zooxanthella. Journal of Molluscan Studies 57:75-85.

Kita A, Jimbo M, Sakai R, Morimoto Y, Miki K (2015) Crystal structure of a symbiosis-related lectin from octocoral. Glycobiology 25:1016-1023.

Kleypas JA, Yates KK (2009) Coral reefs and ocean acidification. Oceanography 22:108-117.

Knowlton N, Brainard RE, Fisher R, Moews M, Plaisance L, Caley MJ (2010) Coral reef biodiversity. In: McIntyre $\mathrm{AD}$ (ed) Life in the World's Oceans: Diversity, Distribution, and Abundance. Blackwell Publishing, Oxford, pp 65-77.

Koike K, Jimbo M, Sakai R, Kaeriyama M, Muramoto K, Ogata T, Maruyama T, Kamiya H (2004) Octocoral chemical signaling selects and controls dinoflagellate symbionts. Biological Bulletin 207:80-86.

Kopp C, Domart-Coulon I, Barthelemy D, Meibom A (2016) Nutritional input from 
dinoflagellate symbionts in reef-building corals is minimal during planula larval life stage. Science Advances 2:e1500681.

Kühlbrandt W (2004) Biology, structure and mechanism of P-type ATPases. Nature Reviews Molecular Cell Biology 5:282-295.

Ladner JT, Barshis DJ, Palumbi SR (2012) Protein evolution in two co-occurring types of Symbiodinium: an exploration into the genetic basis of thermal tolerance in Symbiodinium clade D. BMC Evolutionary Biology 12:217.

LaJeunesse T, Trench RK (2000) Biogeography of two species of Symbiodinium (Freudenthal) inhabiting the intertidal sea anemone Anthopleura elegantissima (Brandt). Biological Bulletin 199:126-34.

LaJeunesse TC (2002) Diversity and community structure of symbiotic dinoflagellates from Caribbean coral reefs. Marine Biology 141:387-400.

LaJeunesse TC (2001) Investigating the biodiversity, ecology, and phylogeny of endosymbiotic dinoflagellates in the genus Symbiodinium using the ITS region: in search of a "species" level marker. Journal of Phycology 37:866-880.

LaJeunesse TC (2005) "Species" radiations of symbiotic dinoflagellates in the Atlantic and Indo-Pacific since the Miocene-Pliocene transition. Molecular Biology and Evolution 22:570-581.

LaJeunesse TC, Parkinson JE, Reimer JD (2012) A genetics-based description of Symbiodinium minutum sp. nov. and S. psygmophilum sp. nov. (dinophyceae), two dinoflagellates symbiotic with cnidaria. Journal of Phycology 48:1380-1391.

Leal MC, Nunes C, Alexandre D, da Silva TL, Reis A, Dinis MT, Calado R (2012) Parental diets determine the embryonic fatty acid profile of the tropical nudibranch Aeolidiella stephanieae: the effect of eating bleached anemones. Marine Biology 159:1745-1751.

Lee SY, Jeong HJ, Kang NS, Jang TY, Jang SH, Lajeunesse TC (2015) Symbiodinium tridacnidorum sp. nov., a dinoflagellate common to Indo-Pacific giant clams, and a revised morphological description of Symbiodinium microadriaticum Freudenthal, emended Trench \& Blank. European Journal of Phycology 50:155-172.

Leggat W, Buck BH, Grice A, Yellowlees D (2003) The impact of bleaching on the metabolic contribution of dinoflagellate symbionts to their giant clam host. Plant, Cell and Environment 26:1951-1961.

Leggat W, Hoegh-Guldberg O, Dove S, Yellowlees D (2007) Analysis of an EST library from the dinoflagellate (Symbiodinium sp.) symbiont of reef-building corals. Journal of Phycology 43:1010-1021.

Leggat W, Yellowlees D, Medina M (2011) Recent progress in Symbiodinium transcriptomics. Journal of Experimental Marine Biology and Ecology 408:120125.

Lesser MP (2006) Oxidative stress in marine environments: biochemistry and physiological ecology. Annual Review of Physiology 68:253-278.

Lima LA De, Migliolo L, Castro CBE, Pires DO, López-Abarrategui C, Gonçalves EF, Vasconcelos IM, Oliveira JTA De, Otero-Gonzalez ADJ, Franco OL, Dias SC (2013) Identification of a novel antimicrobial peptide from Brazilian coast coral Phyllogorgia dilatata. Protein and Peptide Letters 20:1153-1158.

Lin S, Cheng S, Song B, Zhong X, Lin X, Li W, Li L, Zhang Y, Zhang H, Ji Z, Cai M, Zhuang Y, Shi X, Lin L, Wang L, Wang Z, Liu X, Yu S, Zeng P, et al (2015) The Symbiodinium kawagutii genome illuminates dinoflagellate gene expression and coral symbiosis. Science 350:691-694.

Little AF, van Oppen MJH, Willis BL (2004) Flexibility in algal endosymbioses shapes growth in reef corals. Science 304:1492-1494. 
Loh WKW, Cowlishaw M, Wilson NG (2006) Diversity of Symbiodinium dinoflagellate symbionts from the Indo-Pacific sea slug Pteraeolidia ianthina (Gastropoda: Mollusca). Marine Ecology Progress Series 320:177-184.

Mansour MP, Volkman JK, Jackson AE, Blackburn SI (1999) The fatty acid and sterol composition of two marine dinoflagellates. Journal of Phycology 35:710-720.

Mariani S, Piscitelli MP, Uriz M-J (2001) Temporal and spatial co-occurrence in spawning and larval release of Cliona viridis (Porifera: Hadromerida). Journal of the Marine Biological Association of the United Kingdom 81:565-567.

Mariani S, Uriz MJ, Turon X (2000) Larval bloom of the oviparous sponge Cliona viridis: coupling of larval abundance and adult distribution. Marine Biology 137:783-790.

Marlow HQ, Martindale MQ (2007) Embryonic development in two species of scleractinian coral embryos: Symbiodinium localization and mode of gastrulation. Evolution \& Development 9:355-367.

Masood A, Stark KD, Salem Jr. N (2005) A simplified and efficient method for the analysis of fatty acid methyl esters suitable for large clinical studies. Journal of Lipid Research 46:2299-2305.

McGinty ES, Pieczonka J, Mydlarz LD (2012) Variations in reactive oxygen release and antioxidant activity in multiple Symbiodinium types in response to elevated temperature. Microbial Ecology 64:1000-1007.

Meade JC, Li C, Stiles JK, Moate ME, Penny JI, Krishna S, Finley RW (2000) The Trypanosoma cruzi genome contains ion motive ATPase genes which closely resemble Leishmania proton pumps. Parasitology International 49:309-320.

Mellas RE, McIlroy SE, Fitt WK, Coffroth MA (2014) Variation in symbiont uptake in the early ontogeny of the upside-down jellyfish, Cassiopea spp. Journal of Experimental Marine Biology and Ecology 459:38-44.

Meyer E, Aglyamova G V., Matz M V . (2011) Profiling gene expression responses of coral larvae (Acropora millepora) to elevated temperature and settlement inducers using a novel RNA-Seq procedure. Molecular Ecology 20:3599-3616.

Mieog JC, Olsen JL, Berkelmans R, Bleuler-Martinez SA, Willis BL, van Oppen MJH (2009) The roles and interactions of symbiont, host and environment in defining coral fitness. PLoS ONE 4:e6364.

Mies M, Braga F, Scozzafave MS, Lemos D, Sumida PYG (2012) Early development, survival and growth rates of the giant clam Tridacna crocea (Bivalvia: Tridacnidae). Brazilian Journal of Oceanography 60:129-135.

Mies M, Braga F, Scozzafave MS, Sumida PYG, Lemos D (2013) Successful spawning and a possible solution for broodstock mortality in giant clams (Tridacnidae): A neurotransmitter injection through the byssal orifice. Aquaculture Research 44:671-676.

Mies M, Dor P, Güth AZ, Sumida PYG (2017a) Production in giant clam aquaculture: trends and challenges. Reviews in Fisheries Science and Aquaculture. doi: 10.1080/23308249.2017.1285864

Mies M, Scozzafave MS, Braga F, Sumida PYG (2017b) Giant clam aquaculture. In: Calado R, Olivotto I, Planas M, Holt GJ (eds) Marine Ornamental Species Aquaculture. Wiley-Blackwell Publishing, New Jersey.

Mies M, Sumida PYG (2012) Giant clam aquaculture: a review on induced spawning and larval rearing. International Journal of Marine Science 2:62-69.

Mies M, Van Sluys MA, Metcalfe CJ, Sumida PYG (2017c) Molecular evidence of symbiotic activity between Symbiodinium and Tridacna maxima larvae. Symbiosis. doi: 10.1007/s13199-016-0433-8 
Moberg F, Folke C (1999) Ecological goods and services of coral reef ecosystems. Ecological Economics 29:215-233.

Mohamed AR, Cumbo V, Harii S, Shinzato C, Chan CX, Ragan MA, Bourne DG, Willis BL, Ball EE, Satoh N, Miller DJ (2016) The transcriptomic response of the coral Acropora digitifera to a competent Symbiodinium strain: the symbiosome as an arrested early phagosome. Molecular Ecology 25:3127-3141.

Møller J V, Juul B, le Maire M (1996) Structural organization, ion transport, and energy transduction of P-type ATPases. Biochimica et Biophysica Acta 1286:1-51.

Mordret S, Romac S, Henry N, Colin S, Carmichael M, Berney C, Audic S, Richter DJ, Pochon X, de Vargas C, Decelle J (2016) The symbiotic life of Symbiodinium in the open ocean within a new species of calcifying ciliate (Tiarina sp.). The ISME Journal 10:1424-1436.

Morse ANC, Iwao K, Baba M, Shimoike K, Hayashibara T, Omori M (1996) An ancient chemosensory mechanism new life to coral reefs. Biological Bulletin 191:149-154.

Mortillaro JM, Pitt KA, Lee SY, Meziane T (2009) Light intensity influences the production and translocation of fatty acids by zooxanthellae in the jellyfish Cassiopea sp. Journal of Experimental Marine Biology and Ecology 378:22-30.

Mungpakdee S, Shinzato C, Takeuchi T, Kawashima T, Koyanagi R, Hisata K, Tanaka M, Goto H, Fujie M, Lin S, Satoh N, Shoguchi E (2014) Massive gene transfer and extensive RNA editing of a symbiotic dinoflagellate plastid genome. Genome Biology and Evolution 6:1408-1422.

Muscatine L (1990) The role of symbiotic algae in carbon and energy flux in coral reefs. In: Dubinsky Z (ed) Ecosystems of the World. Elsevier, Amsterdam, pp 7587.

Muscatine L, McCloskey LR, Marian RE (1981) Estimating the daily contribution of carbon from zooxanthellae to coral animal respiration. Limnology and Oceanography 26:601-611.

Muscatine L, Porter JW (1977) Reef corals: mutualistic symbioses adapted to nutrientpoor environments. BioScience 27:454-460.

Nakamura M, Ohki S, Suzuki A, Sakai K (2011) Coral larvae under ocean acidification: survival, metabolism, and metamorphosis. PLOS ONE 6:e14521.

Nesa B, Baird AH, Harii S, Yakovleva I, Hidaka M (2012) Algal symbionts increase DNA damage in coral planulae exposed to sunlight. Zoological Studies 51:12-17.

Nevejan N, Saez I, Gajardo G, Sorgeloos P (2003) Supplementation of EPA and DHA emulsions to a Dunaliella tertiolecta diet: effect on growth and lipid composition of scallop larvae, Argopecten purpuratus (Lamarck, 1819). Aquaculture 217:613632.

Neves EG, Pires DO (2002) Sexual reproduction of Brazilian coral Mussismilia hispida (Verrill, 1902). Coral Reefs 21:161-168.

Newton K, Côté IM, Pilling GM, Jennings S, Dulvy NK (2007) Current and future sustainability of island coral reef fisheries. Current Biology 17:655-658.

Norton JH, Shepherd MA, Long HM, Fitt WK (1992) The zooxanthellal tubular system in the giant clam. Biological Bulletin 183:503-506.

Olivotto I, Planas M, Simões N, Holt GJ, Avella MA, Calado R (2011) Advances in breeding and rearing marine ornamentals. Journal of the World Aquaculture Society 42:135-166.

Pandolfi JM, Bradbury RH, Sala E, Hughes TP, Karen A, Cooke RG, Mcardle D, McClenachan L, Newman MJH, Paredes G, Warner RR, Jackson JBC (2003) Global trajectories of the long-term decline of coral reef ecosystems. Science 
301:955-958.

Papina M, Meziane T, van Woesik R (2003) Symbiotic zooxanthellae provide the hostcoral Montipora digitata with polyunsaturated fatty acids. Comparative Biochemistry and Physiology - B Biochemistry and Molecular Biology 135:533537.

Pardo JM, Serrano R (1989) Structure of a plasma membrane H+-ATPase from the plant Arabidopsis thaliana. The Journal of Biological Chemistry 264:8557-8562.

Patron NJ, Waller RF, Archibald JM, Keeling PJ (2005) Complex protein targeting to dinoflagellate plastids. Journal of Molecular Biology 348:1015-1024.

Pechenik JA (1990) Delayed metamorphosis by larvae of benthic marine invertebrates: does it occur? Is there a price to pay? Ophelia 32:63-94.

Pechenik JA (1999) On the advantages and disadvantages of larval stages in benthic marine invertebrate life cycles. Marine Ecology Progress Series 177:269-297.

Picciani N, de Lossio e Seiblitz IG, de Paiva PC, e Castro CB, Zilberberg C (2016) Geographic patterns of Symbiodinium diversity associated with the coral Mussismilia hispida (Cnidaria, Scleractinia) correlate with major reef regions in the Southwestern Atlantic Ocean. Marine Biology. doi: 10.1007/s00227-016-3010$\mathrm{Z}$

Pires DO, Castro CB, Segal B, Pereira CM, do Carmo EC, da Silva RG, Calderon EN (2016) Reprodução de corais de águas rasas do Brasil. In: Zilberberg C, Abrantes DP, Marques JA, Machado LF, Marangoni LFB (eds) Conhecendo os Recifes Brasileiros. Museu Nacional, Rio de Janeiro, pp 111-128.

Pizay MD, Lemée R, Simon N, Cras AL, Laugier JP, Dolan JR (2009) Night and day morphologies in a planktonic dinoflagellate. Protist 160:565-575.

Pochon X, Gates RD (2010) A new Symbiodinium clade (Dinophyceae) from soritid foraminifera in Hawai'i. Molecular Phylogenetics and Evolution 56:492-497.

Pochon X, Montoya-Burgos JI, Stadelmann B, Pawlowski J (2006) Molecular phylogeny, evolutionary rates, and divergence timing of the symbiotic dinoflagellate genus Symbiodinium. Molecular Phylogenetics and Evolution 38:20-30.

Pochon X, Putnam HM, Gates RD (2014) Multi-gene analysis of Symbiodinium dinoflagellates: a perspective on rarity, symbiosis, and evolution. PeerJ 2:e394.

Polato NR, Voolstra CR, Schnetzer J, DeSalvo MK, Randall CJ, Szmant AM, Medina M, Baums IB (2010) Location-specific responses to thermal stress in larvae of the reef-building coral Montastraea faveolata. PLoS ONE 5:e11221.

Pomeroy RS, Parks JE, Balboa CM (2006) Farming the reef: Is aquaculture a solution for reducing fishing pressure on coral reefs? Marine Policy 30:111-130.

Popova LG, Balnokin Y V. (1992) H+-translocating ATPase and $\mathrm{Na}+\mathrm{H}+$ antiport activities in the plasma membrane of the marine alga Platymonas viridis. Federation of European Biochemical Societies (FEBS) Letters 309:333-336.

Ralph PJ, Larkum AWD, Kühl M (2005) Temporal patterns in effective quantum yield of individual zooxanthellae expelled during bleaching. Journal of Experimental Marine Biology and Ecology 316:17-28.

Ramos MG, Banaszak AT (2014) Symbiotic association between Symbiodinium and the gastropod Strombus gigas: larval acquisition of symbionts. Marine Biotechnology 16:193-201.

Rees TA V., Fitt WK, Baillie B, Yellowlees D (1993) A method for temporal measurement of hemolymph composition in the giant clam symbiosis and its application to glucose and glycerol levels during a diel cycle. Limnology and Oceanography 38:213-217. 
Rivest EB, Hofmann GE (2014) Responses of the metabolism of the larvae of Pocillopora damicornis to ocean acidification and warming. PLoS ONE 9:e96172.

Rodriguez-Lanetty M (2003) Evolving lineages of Symbiodinium-like dinoflagellates based on ITS1 rDNA. Molecular Phylogenetics and Evolution 28:152-168.

Rodriguez-Lanetty M, Chang SJ, Song JI (2003) Specificity of two temperate dinoflagellate-anthozoan associations from the north-western Pacific Ocean. Marine Biology 143:1193-1199.

Rodriguez-Lanetty M, Harii S, Hoegh-Guldberg O (2009) Early molecular responses of coral larvae to hyperthermal stress. Molecular Ecology 18:5101-5114.

Rodriguez-Lanetty M, Krupp DA, Weis VM (2004) Distinct ITS types of Symbiodinium in Clade $\mathrm{C}$ correlate with cnidarian/dinoflagellate specificity during onset of symbiosis. Marine Ecology Progress Series 275:97-102.

Rodriguez-Lanetty M, Wood-Charlson EM, Hollingsworth LL, Krupp DA, Weis VM (2006) Temporal and spatial infection dynamics indicate recognition events in the early hours of a dinoflagellate/coral symbiosis. Marine Biology 149:713-719.

Rosic N, Ling EYS, Chan C-KK, Lee HC, Kaniewska P, Edwards D, Dove S, HoeghGuldberg O (2014) Unfolding the secrets of coral-algal symbiosis. The ISME Journal 9:1-13.

Rosic NN, Hoegh-Guldberg O (2010) A method for extracting a high-quality RNA from Symbiodinium sp. Journal of Applied Phycology 22:139-146.

Rowan R, Knowlton N (1995) Intraspecific diversity and ecological zonation in coralalgal symbiosis. Proceedings of the National Academy of Sciences of the United States of America 92:2850-2853.

Rowan R, Powers DA (1991) Molecular genetic identification of symbiotic dinoflagellates (zooxanthellae). Marine Ecology Progress Series 71:65-73.

Rudman WB (1981) The anatomy and biology of alcyonarian-feeding aeolid opisthobranch molluscs and their development of symbiosis with zooxanthellae. Zoological Journal of the Linnean Society 72:219-262.

Ruess L, Tiunov A, Haubert D, Richnow HH, H??ggblom MM, Scheu S (2005) Carbon stable isotope fractionation and trophic transfer of fatty acids in fungal based soil food chains. Soil Biology and Biochemistry 37:945-953.

Sachs JL, Wilcox TP (2006) A shift to parasitism in the jellyfish symbiont Symbiodinium microadriaticum. Proceedings of the Royal Society B: Biological Sciences 273:425-429.

Sambrook J, Fritsch EF, Maniatis T (eds) (1989) Molecular Cloning. Cold Spring Harbor Laboratory Press, Cold Spring Harbor

Sayers EW, Barrett T, Benson DA, Bolton E, Bryant SH, Canese K, Chetvernin V, Church DM, DiCuccio M, Federhen S, Feolo M, Fingerman IM, Geer LY, Helmberg W, Kapustin Y, Krasnov S, Landsman D, Lipman DJ, Lu Z, et al (2012) Database resources of the National Center for Biotechnology Information. Nucleic Acids Research 40:13-25.

Schnitzler CE, Hollingsworth LL, Krupp DA, Weis VM (2012) Elevated temperature impairs onset of symbiosis and reduces survivorship in larvae of the Hawaiian coral, Fungia scutaria. Marine Biology 159:633-642.

Schnitzler CE, Weis VM (2010) Coral larvae exhibit few measurable transcriptional changes during the onset of coral-dinoflagellate endosymbiosis. Marine Genomics 3:107-116.

Schoenberg DA, Trench RK (1980) Genetic variation in Symbiodinium (=Gymnodinium) microadriaticum Freudenthal, and specificity in its symbiosis with marine invertebrates. I. Isoenzyme and soluble protein patterns of axenic 
cultures of Symbiodinium microadriaticum. Proceedings of the Royal Society B: Biological Sciences 207:405-427.

Schwarz JA, Krupp DA, Weis VM (1999) Late larval development and onset of symbiosis in the scleractinian coral Fungia scutaria. Biological Bulletin 196:7079.

Schwarz JA, Weis VM, Potts DC (2002) Feeding behavior and acquisition of zooxanthellae by planula larvae of the sea anemone Anthopleura elegantissima. Marine Biology 140:471-478.

Sheppard CRC, Davy SK, Pilling GM (eds) (2009) The Biology of Coral Reefs. Oxford University Press, Oxford.

Shoguchi E, Shinzato C, Kawashima T, Gyoja F, Mungpakdee S, Koyanagi R, Takeuchi T, Hisata K, Tanaka M, Fujiwara M, Hamada M, Seidi A, Fujie M, Usami T, Goto H, Yamasaki S, Arakaki N, Suzuki Y, Sugano S, et al (2013) Draft assembly of the Symbiodinium minutum nuclear genome reveals dinoflagellate gene structure. Current Biology 23:1399-1408.

Slattery M, Hines GA, Starmer J, Paul VJ (1999) Chemical signals in gametogenesis, spawning, and larval settlement and defense of the soft coral Sinularia polydactyla. Coral Reefs 18:75-84.

Stat M, Carter D, Hoegh-Guldberg O (2006) The evolutionary history of Symbiodinium and scleractinian hosts-symbiosis, diversity, and the effect of climate change. Perspectives in Plant Ecology, Evolution and Systematics 8:23-43.

Strathmann RR, Hughes TP, Kuris AM, Lindeman KC, Morgan SG, Pandolfi JM, Warner RR (2002) Evolution of local recruitment and its consequences for marine populations. Bulletin of Marine Science 70:377-396.

Strychar KB, Coates M, Sammarco PW, Piva TJ, Scott PT (2005) Loss of Symbiodinium from bleached soft corals Sarcophyton ehrenbergi, Sinularia sp. and Xenia sp. Journal of Experimental Marine Biology and Ecology 320:159-177.

Tamura K, Peterson D, Peterson N, Stecher G, Nei M, Kumar S (2011) MEGA5: Molecular evolutionary genetics analysis using maximum likelihood, evolutionary distance, and maximum parsimony methods. Molecular Biology and Evolution 28:2731-2739.

Tanaka Y, Inoue M, Nakamura T, Suzuki A, Sakai K (2014) Loss of zooxanthellae in a coral under high seawater temperature and nutrient enrichment. Journal of Experimental Marine Biology and Ecology 457:220-225.

Taylor DL (1974) Symbiotic marine algae: taxonomy and biological fitness. In: Vernberg WB (ed) Symbiosis in the Sea. University of South Carolina Press, Columbia, pp 245-262.

Tchernov D, Gorbunov MY, de Vargas C, Narayan Yadav S, Milligan AJ, Häggblom M, Falkowski PG (2004) Membrane lipids of symbiotic algae are diagnostic of sensitivity to thermal bleaching in corals. Proceedings of the National Academy of Sciences of the United States of America 101:13531-13535.

Thorson G (1950) Reproductive and larval ecology of marine bottom invertebrates. Biological Reviews of the Cambridge Philosophical Society 25:1-45.

Titlyanov EA, Titlyanova T V., Loya Y, Yamazato K (1998) Degradation and proliferation of zooxanthellae in planulae of the hermatypic coral Stylophora pistillata. Marine Biology 130:471-477.

Toulza E, Shin MS, Blanc G, Audic S, Laabir M, Collos Y, Claverie JM, Grzebyk D (2010) Gene expression in proliferating cells of the dinoflagellate Alexandrium catenella (Dinophyceae). Applied and Environmental Microbiology 76:4521-4529.

Trench RK (1979) The cell biology of plant-animal symbiosis. Annual Review of Plant 
Physiology 30:485-531.

Trench RK, Wethey DS, Porter JW (1981) Observations on the symbiosis with zooxanthellae among the Tridacnidae (Mollusca, Bivalvia). Biological Bulletin 161:180-198.

Trench RK, Winsor H (1987) Symbiosis with dinoflagellates in two pelagic flatworms, Amphiscolops sp. and Haplodiscus sp. Symbiosis 3:1-22.

van Oppen MJH, Mahiny AJ, Done TJ (2005) Geographic distribution of zooxanthella types in three coral species on the Great Barrier Reef sampled after the 2002 bleaching event. Coral Reefs 24:482-487.

Venn AA, Loram JE, Douglas AE (2008) Photosynthetic symbioses in animals. Journal of Experimental Botany 59:1069-1080.

Venn AA, Wilson MA, Trapido-Rosenthal HG, Keely BJ, Douglas a. E (2006) The impact of coral bleaching on the pigment profile of the symbiotic alga, Symbiodinium. Environment 29:2133-2142.

Vermeij MJA, Frade PR, Bak RPM (2013) Zooxanthellae presence acts as a settlement cue for aposymbiotic planulae of the Caribbean Coral Montastraea faveolata. Caribbean Journal of Science 47:31-36.

Volkman JK, Jeffrey SW, Nichols PD, Rogers GI, Garland CD (1989) Fatty acid and lipid composition of 10 species of microalgae used in mariculture. Journal of Experimental Marine Biology and Ecology 128:219-240.

Voolstra CR, Schnetzer J, Peshkin L, Randall CJ, Szmant AM, Medina M (2009a) Effects of temperature on gene expression in embryos of the coral Montastraea faveolata. BMC Genomics 10:1-9.

Voolstra CR, Schwarz JA, Schnetzer J, Sunagawa S, Desalvo MK, Szmant AM, Coffroth MA, Medina M (2009b) The host transcriptome remains unaltered during the establishment of coral-algal symbioses. Molecular Ecology 18:1823-1833.

Waldbusser GG, Brunner EL, Haley BA, Hales B, Langdon CJ, Prahl FG (2013) A developmental and energetic basis linking larval oyster shell formation to acidification sensitivity. Geophysical Research Letters 40:2171-2176.

Wasmund N, Topp I, Schories D (2006) Optimising the storage and extraction of chlorophyll samples. Oceanologia 48:125-144.

Wecker P, Fournier A, Bosserelle P, Debitus C, Lecellier G, Berteaux-Lecellier V (2015) Dinoflagellate diversity among nudibranchs and sponges from French Polynesia: insights into associations and transfer. Comptes Rendus Biologies 338:278-283.

Weis VM (2008) Cellular mechanisms of cnidarian bleaching: stress causes the collapse of symbiosis. The Journal of Experimental Biology 211:3059-3066.

Weis VM, Davy SK, Hoegh-Guldberg O, Rodriguez-Lanetty M, Pringle JR (2008) Cell biology in model systems as the key to understanding corals. Trends in Ecology and Evolution 23:369-376.

Weis VM, Reynolds WS, DeBoer MD, Krupp DA (2001) Host-symbiont specificity during onset of symbiosis between the dinoflagellates Symbiodinium spp. and planula larvae of the scleractinian coral Fungia scutaria. Coral Reefs 20:301-308.

Welschmeyer NA (1994) Fluorometric analysis of chlorophyll $a$ in the presence of chlorophyll $b$ and pheopigments. Limnology and Oceanography 39:1985-1992.

Wilkerson FP (1983) Temporal patterns of cell division in natural populations of endosymbiotic algae. Limnology and Oceanography 28:1009-1014.

Wilkinson DM, Sherratt TN (2001) Horizontally acquired mutualisms, an unsolved problem in ecology? Oikos 92:377-384.

Wolfowicz I, Baumgarten S, Voss PA, Hambleton EA, Voolstra CR, Hatta M, Guse A 
(2016) Aiptasia sp. larvae as a model to reveal mechanisms of symbiont selection in cnidarians. Scientific Reports 6:32366.

Wood-Charlson EM, Hollingsworth LL, Krupp DA, Weis VM (2006) Lectin/glycan interactions play a role in recognition in a coral/dinoflagellate symbiosis. Cellular Microbiology 8:1985-1993.

Wray GA, Raff RA (1991) The evolution of developmental strategy in marine invertebrates. Trends in Ecology and Evolution 6:45-50.

Yacobovitch T, Benayahu Y, Weis VM (2004) Motility of zooxanthellae isolated from the Red Sea soft coral Heteroxenia fuscescens (Cnidaria). Journal of Experimental Marine Biology and Ecology 298:35-48.

Yakovleva IM, Baird AH, Yamamoto HH, Bhagooli R, Nonaka M, Hidaka M (2009) Algal symbionts increase oxidative damage and death in coral larvae at high temperatures. Marine Ecology Progress Series 378:105-112.

Zhukova N, Aizdaicher NA (1995) Fatty acid composition of 15 species of marine microalgae. Phytochemistry 39:351-356.

Zhukova N V., Titlyanov EA (2003) Fatty acid variations in symbiotic dinoflagellates from Okinawan corals. Phytochemistry 62:191-195. 